\section{OAK RIDGE NATIONAL LABORATORY}

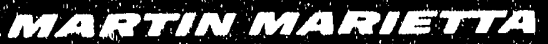

\section{Ecological Effects of Contaminants in McCoy Branch, 1989-19S0}

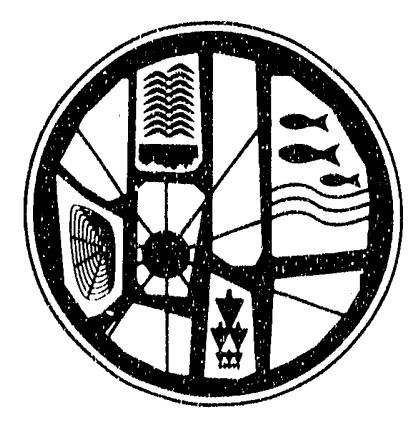

MARTIN MARIETTA ENERGY SYSTEMS, INC.

FOR THE UNITED STATES

DEPARTMENT OF ENERGY 
This report has been reproduced directly from the best avallable copy.

Avallable to DOE and DOE contractors from the Office of Scientfic and Technical Information, P.O. Box 62, Oak Fidge, TN 37831 ; prices available from (615) 576-8401, FTS 626-8401.

Available to the public from the National Technical Information Service, U.S. Department of Commerce, 5285 Port Royal Rd., Springtield, VA 22161.

This report was prepared as an account of work sponsored by an agency of the United States Government. Neither the United States Government nor any agency thereof, nor any of their employees, makes any warranty, express or implied, or assumes any legal llability or responsibility for the accuracy, completeness, or usefulness of any information, apparatus, product, or process disclosed, or represents that its use would not infringe privately owned rights. Reference herein to any specific commerclal product, process, or service by trade name, trademark, manufacturer, or otherwise, does not necessarily constitute or imply its endorsement, recommendation, or favoring by the United States Government or any agency thereof. The vlews and opinions of authors expressed herein do not necessarlly state or reflect those of the United States Government or any agency thereof. 


\title{
ECOLOGICAL EFFECTS OF CONTAMINANTS IN MCCOY BRANCH, 1989-1990
}

Editor

M. G. Ryon

\section{Contributors}

\author{
R. L. Hinzman ${ }^{1}$ \\ M. J. Peterson ${ }^{2}$ \\ T. D. Richardson ${ }^{3}$ \\ M. G. Ryon \\ J. G. Smith \\ G. R. Southworth \\ A. J. Stewart \\ V. R. Tolbert \\ Environmental Sciences Division \\ Publication No. 3837
}

'Oak Ridge Research Institute, Oak Ridge, Tennessee

${ }^{2}$ Automated Sciences Group, Inc., Oak Ridge, Tennessee

${ }^{3}$ Postdoctoral Associate, Oak Ridge Associated Universities

Date of Issue--January 1992

Prepared for

S. Walker

Environmental Restoration Program

Y-12 Plant

Oak Ridge, Tennessee 378.31

Prepared by the

OAK RIDGE NATIONAL LABORATORY

Oak Ridge, Tennessee 37831-6285

managed by

MARTIN MARIETTA ENERGY SYSTEMS, INC.

for the

U.S. DEPARTMENT OF ENERGY

under contract DE-AC05-84OR21400 


\section{CONTENTS}

Page

LIST OF FIGURES $\ldots \ldots \ldots \ldots \ldots \ldots \ldots \ldots \ldots \ldots \ldots \ldots \ldots \ldots$

LIST OF TABLES $\ldots \ldots \ldots \ldots \ldots \ldots \ldots \ldots \ldots \ldots \ldots \ldots \ldots \ldots \ldots \ldots$

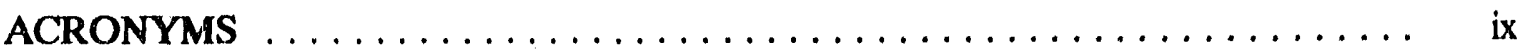

ACKNOWLEDGMENTS $\ldots \ldots \ldots \ldots \ldots \ldots \ldots \ldots \ldots \ldots \ldots \ldots \ldots \ldots$

EXECUTTVE SUMMARY $\ldots \ldots \ldots \ldots \ldots \ldots \ldots \ldots \ldots \ldots \ldots \ldots \ldots \ldots \ldots$

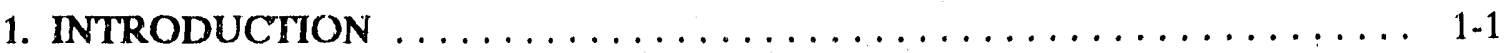

2. DESCRIPTION OF THE MCCOY BRANCH WATERSHED

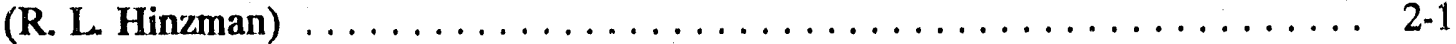

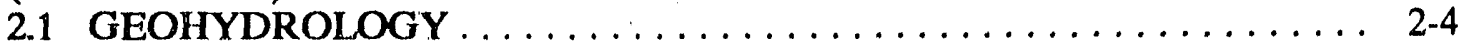

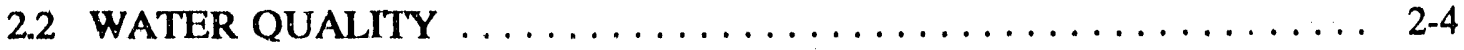

2.2.1 Description and History of Discharges to McCoy Branch

and Rogers Quarry . . . . . . . . . . . . . . . . . . . . 2-4

2.2.2 Characterization of the Contaminant Source $\ldots \ldots \ldots \ldots \ldots \ldots$ 2-5

2.2 .3 Temperature . . . . . . . . . . . . . . . . . . . . 2 2-6

2.2.4 Sediments and Groundwater $\ldots \ldots \ldots \ldots \ldots \ldots \ldots \ldots \ldots \ldots \ldots$

3. TOXICITY MONITORING (A. J. Stewart and T. D. Richardson) . . . . . . 3-1

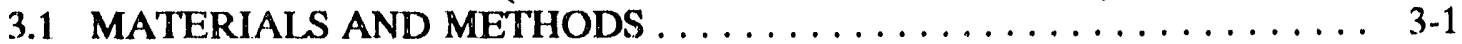

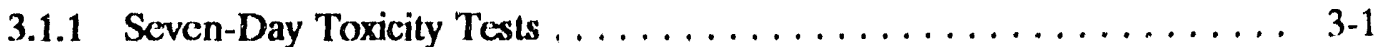

3.1.2 Full Life-Cycle Tests . . . . . . . . . . . . . . . . . 3-1

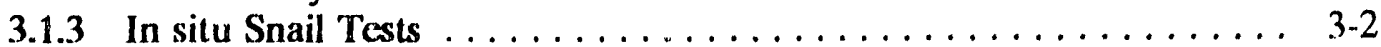

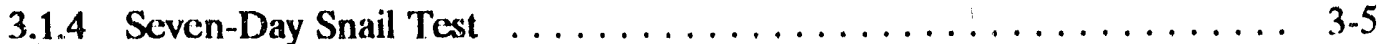

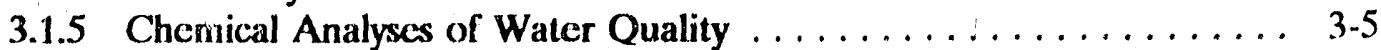

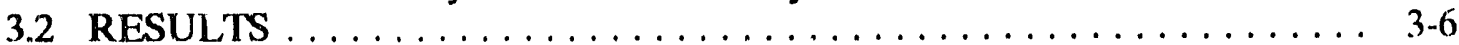

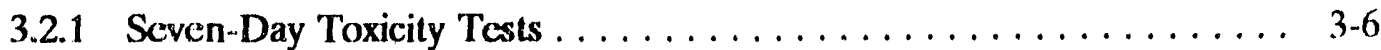

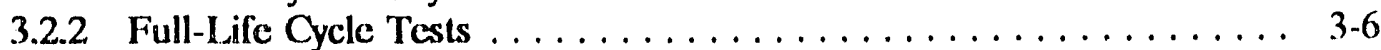

3.2.3 In Situ Snail Test . . . . . . . . . . . . . . . . . . . 3-10

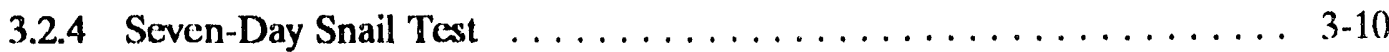

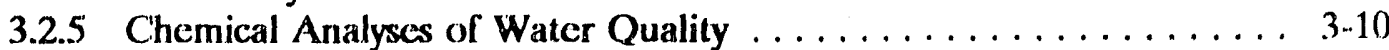

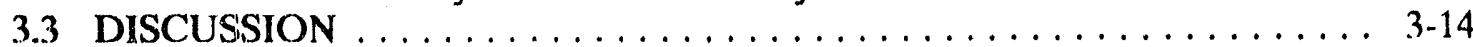

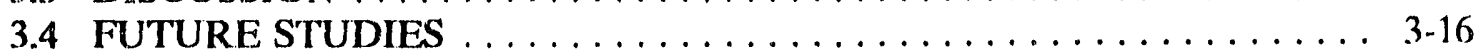

4. BIOACCUMULATION STUDIES (G. R. Southworth and M. J. Peterson) . . . 4-1

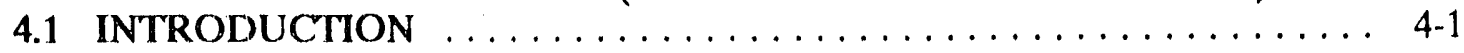

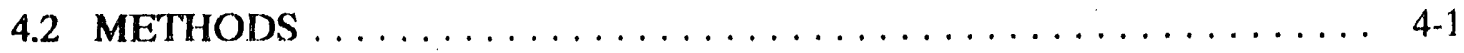

4.3 RESULTS AND DISCUSSION $\ldots \ldots \ldots \ldots \ldots \ldots \ldots \ldots \ldots \ldots$. $4 \ldots \ldots \ldots \ldots$

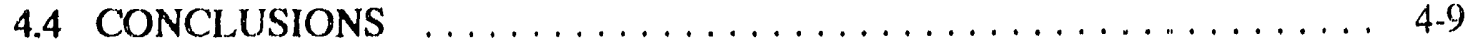

4.5 FUTURE STUDIES $\ldots \ldots \ldots \ldots \ldots \ldots \ldots \ldots \ldots \ldots \ldots \ldots \ldots$ 4-10 
CONTENTS (Continued)

Page

5. FISH COMMUNITY ASSESSMENT (M. G. Ryon) $\ldots \ldots \ldots \ldots \ldots \ldots \ldots \ldots$.1

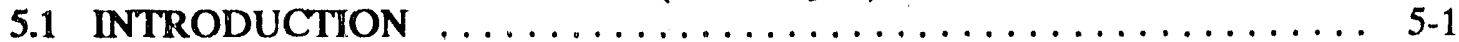

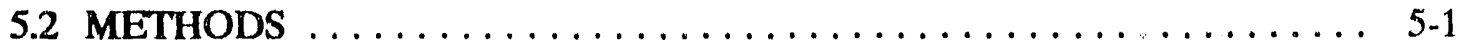

5.3 RESULTS AND DISCUSSION $\ldots \ldots \ldots \ldots \ldots \ldots \ldots \ldots \ldots \ldots \ldots$

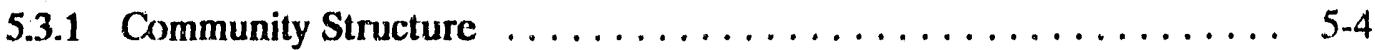

5.3.2 Population Densities ... . . . . . . . . . . . . . . . 5-6

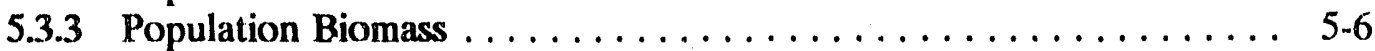

5.3 .4 Length Frequency $\ldots \ldots \ldots \ldots \ldots \ldots \ldots \ldots \ldots \ldots \ldots \ldots$

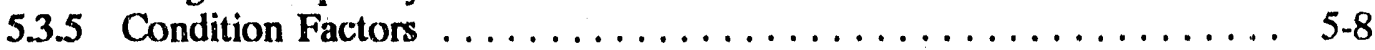

5.3.6 Observed Abnormalities $\ldots \ldots \ldots \ldots \ldots \ldots \ldots \ldots \ldots \ldots . \ldots \ldots$

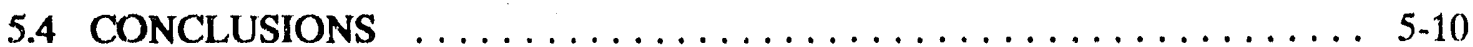

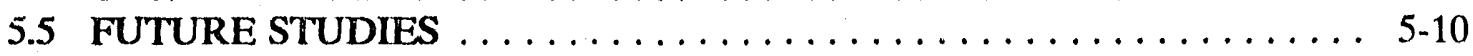

6. BENTHIC MACROINVERTEBRATE COMMUNITY ASSESSMENT

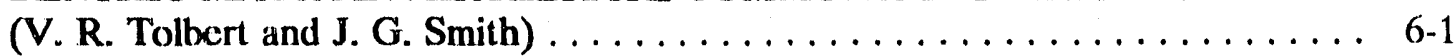

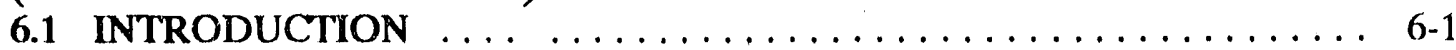

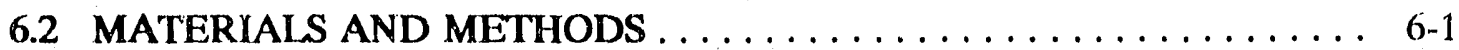

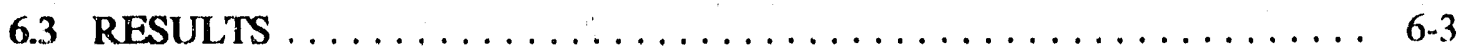

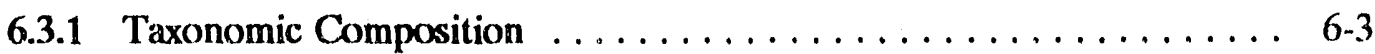

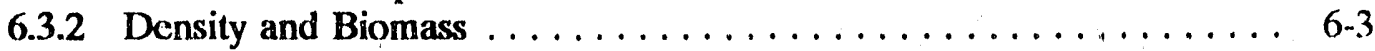

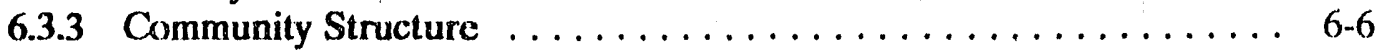

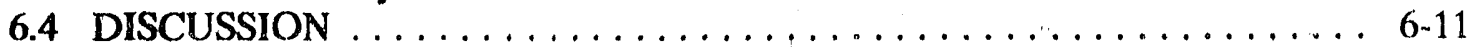

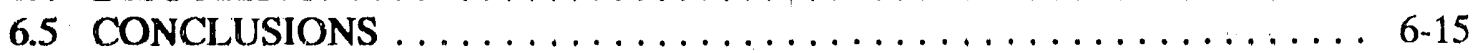

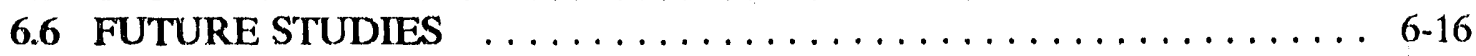

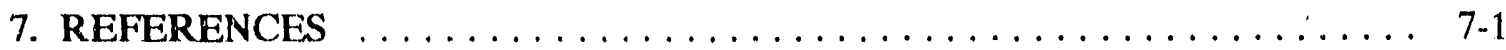

APPENDIX A. WATER QUALITY DATA FOR MCCOY
BRANCH WATERSHED FOR $1974-1990 \ldots \ldots \ldots \ldots \ldots \ldots$ A-1

APPENDIX B. CHECKLIST OF BENTHIC MACROINVERTEBRATE TAXA FROM MCCOY BRANCH AND WHITE OAK CREEK, APRIL 1989-JANUARY $1990 \ldots \ldots \ldots \ldots \ldots \ldots \ldots \ldots$ 


\section{LIST OF FIGURES}

Figure

Page

2-1 Map of the Oak Ridge area showing locations of the reference sites $\ldots \ldots \ldots$ 2-2

2-2 Map of the McCoy Branch showing the primary features and monitoring sites . . . . . . . . . . . . . . . . . .

2-3 Mean weekly values for sulfate in the water from McCoy Branch at Outfall 302, below Rogers Quarry, from 1986 to $1990 \ldots \ldots \ldots \ldots \ldots$. $2-8$

2-4 Mean weekly values for arsenic in the water from McCoy Branch at Outfall 302, below Rogers Quarry, from 1986 to $1990 \ldots \ldots$. . . . . . . 2-9

2-5 Mean weekly values for selenium in water from McCoy Branch at Outfall 302, Rogers Quarry, from 1986 to $1990 \ldots \ldots \ldots \ldots \ldots \ldots$. . . . . . .

2-6 Weekly mean temperature for McCoy Branch, and for two reference sites, upper White Oak Creek and upper Fifth Creek

3-1 Plot showing the number of snails recovered versus distance from the point of release for two sites in McCoy Branch and a noncontaminated site in White Oak Creek

5-1 Length-frequency histograms for bluegill sunfish, green sunfish, and bluntnose minnow for May 1989, October 1989, and May 1990 from McCoy Branch site MCK $1.56 \ldots \ldots \ldots \ldots \ldots \ldots \ldots \ldots \ldots \ldots \ldots$

6-1 Mean seasonal density and biomass of benthic macroinvertebrates in McCoy Branch and White Oak Creek, April 1989 to January 1990 . . . . .

6-2 Mean scasonal density for selected taxa in McCoy Branch and White Oak Creek, April 1989 to January $1990 \ldots \ldots \ldots \ldots \ldots \ldots . \ldots .6$

6-3 Mean seasonal biomass for selected taxa in McCoy Branch and White Oak Creek, April 1989 to January 1990 . . . . . . . . . . . . . . . . . .

6-4 Mean scasonal taxonomic richness of benthic macroinvertebrates in McCoy Branch and White Oak Creck, April 1989 to January 1990 . . . . 6-10

6-5 Mean scasonal Ephemeroptera, Plecoptera, and Trichoptera richness in McCoy Branch and Whitc Oak Crcek, April 1989 to January 1990

66 Mean scasonal diversity of benthic macroinvertebrates in McCoy Branch and Whitc Oak Creck, April 1989 to January 199() 


\section{LIST OF TABLES}

Table

Page

2-1 Mean (standard error) for selected National Pollutant Discharge Elimination System water quality parameters for Outfall 302 for 1986 to $1990 \ldots \ldots \ldots$. 2-7

2-2 Arsenic levels in McCoy Branch on March 15, $1990 \ldots \ldots \ldots \ldots \ldots \ldots$. . . . . .

3-1 Results of 7-d toxicity tests (fathead minnow larvae and Ceriodaphnia dubia) of water from McCoy Branch at MCK 1.92 ............... 3-3

3-2 Results of 7-d toxicity tests (fathead minnow larvae and Ceriodaphnia) of water from McCoy Branch at the spring ncar the base of the ash pond dam (spring) and from McCoy Branch below Rogers Quarry .............

3-3 Means of Ceriodaphnia survival and reproduction parameters for life-cycle tests with control water, water from McCoy Branch at the inlet to Rogers Quarry, and water from East Fork Poplar Creek at the outfall of Lake

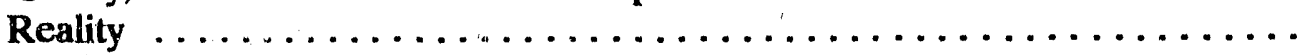

3-4 Analysis of variance results for Ceriodaphnia life-cycle tests of control water and water from McCoy Branch at MCK $1.92 \ldots \ldots \ldots \ldots \ldots \ldots$

3-5 Analysis of variance results for Ceriodaphnia life-cycle tests of water from Lake Reality outfall and McCoy Branch at MCK $1.92 \ldots \ldots \ldots \ldots \ldots$

3-6 Means of $\mathrm{pH}$, conductivity, alkalinity, and hardness for daily grab samples of water from McCoy Branch at MCK $1.92 \ldots \ldots \ldots \ldots \ldots \ldots \ldots$

3-7 Means of nitrate, phosphate, and sulfate concentrations in daily drab samples of water from McCoy Branch at MCK 1.92 and the spring near the base of the ash pond dam $\ldots \ldots \ldots \ldots \ldots \ldots \ldots \ldots \ldots \ldots \ldots \ldots \ldots \ldots$

3-8 Means of $\mathrm{pH}$, conductivity, alkalinity, and hardness for daily grab samples of water from McCoy Branch at MCK 1.60) (July 30-August 5, 1990) and the spring at the base of the ash pond dam (April 5-11, 1990)

4-1 Concentrations of metals in individual fish collected in Rogers Quarry, McCoy Branch embayment, and a reference stream, Hinds Creck, July 1990

4-2 Metal concentrations in largernouth bass (Microptenus salmoides) from Rogers Quarry and McCoy Branch embayment and sunfish (Lepomis auritus and L. macrochinus) from Hinds Creek, a reference stream 
LIST OF TABLES (Continued)

Table

Page

4-3 Concentrations of chlorinated pesticides and PCBs in fish from Rogers

Quarry, and Hinds Creek July $1990 \ldots \ldots \ldots \ldots \ldots \ldots \ldots \ldots$

5-1 Length, mean width, mean depth, area, and pool-riffle ratio of fish sampling sites on McCoy Branch and two reference streams,

Grassy Creek and White Oak Creek, for each sampling date $\ldots \ldots \ldots \ldots \ldots$ 5-3

5-2 Fish densities in McCoy Branch and in two reference streams, White Oak Creek and Grassy Creek, for April-May 1989 to April-May 1990 . . . . . . 5-5

5-3 Fish biomass in McCoy Branch and in two reference streams, White Oak Creek and Grassy Creek, for April-May 1989 to April-May 1990 . . . . . . . 5-7

6-1 Mean annual density, biomass, taxonomic richness, Ephemeroptera, Plecoptera, and Trichoptera richness, and diversity of benthic macroinvertebrates in McCoy Branch and White Oak Creek, April 1989 to January 1990

6-2 Statistical comparisons of mean annual benthic macroinvertebrate density, biomass, taxonomic richness, Ephemeroptera, Plectoptera, and Trichoptera richness, and species diversity in McCoy Branch and the reference stream, White Oak Creek 


\section{ACRONYMS}

\begin{tabular}{ll} 
AA & Atomic Absorption Spectroscopy \\
ACD & Analytical Chemistry Division \\
ANOVA & Analysis of Variation \\
BMAP & Biological Monitoring and Abatement Program \\
CPI & Cohort production interval \\
DDE & dichlorodiphenyldichloroethylene \\
DDT & dichlorodiphenyltrichloroethane \\
DEM & Department of Environmental Management \\
DO & Dissolved oxygen \\
DOE & Department of Energy \\
EFK & East Fork Poplar Creek kilometer \\
EFPC & East Fork Poplar Creek \\
EPA & U.S. Environmental Protection Agency \\
EPT & Ephemeroptera, Plecoptera, and Trichoptera richness \\
ES & Emission Spectroscopy \\
ESD & Environmental Sciences Division, ORNL \\
FDA & U.S. Food and Drug Administration \\
G & Value derived from a median test for multiple samples \\
GCK & Grassy Creek kilometer \\
GC/ECD & Gas chromatography/electron capture detector \\
GC/MS & Gas chromatography/mass spectrophotometry \\
HESA & Department of Health, Safety, and Environmental Affairs \\
HSRD & Health and Safety Research Division \\
LCT & Life-Cycle Test \\
LOEC & Lowest observed-effect level \\
LR-O & Lake Reality outfall \\
MAF & Mean annual flow \\
MCK & McCoy Branch kilometer \\
NOEC & No observed-effect concentration \\
NPDES & National Pollutant Discharge Elimination System \\
ORNL & Oak Ridge National Laboratory \\
ORR & Oak Ridge Reservation \\
PAH & Polycyclic aromatic hydrocarbons \\
P/B & Production/biomass \\
PCB & Polychlorinated biphenyl \\
PGV & Preliminary guidance values \\
PPM & Parts per million \\
QA & Quality Assurance \\
RCRA & Resource Conservation and Recovery Act \\
RFI & RCRA Facilitics Investigation \\
RQ & Rogers Quarry \\
SD & Standard deviation \\
SE & Standard error \\
TDC & Tennessee Department of Conservation \\
TL & Total length \\
TRC & Total residual chlorine \\
& \\
\hline
\end{tabular}


Toxicity reduction evaluation

Toxic Substances Control Act

Total suspended solids

Tennessee Valley Authority

White Oak Creek kilometer

WCK

White Oak Creek 


\section{ACKNOWLFDGMENTS}

We thank D. K. Cox, W. C. Kyker, L. M. Stubbs, W. M. Harris, B. A. Carrico, E. M. Schilling, R. D. Bailey, P. W. Braden, L. S. Ewald, L. A. Kszos, G. P. Morris, and L. F. Wicker for their assistance in the laboratory and/or field. We thank M. Maskarinec, N. M. Ferguson, and other staff of the Oak Ridge National Laboratory Analytical Chemistry Division for sample analysis. We thank B. F. Clark, W. D. Dickinson, A. W. McWhorter, and J. A. Wojtowicz for processing the benthic macroinvertebrate samples. We are grateful to W. R. Hill of The University of Tennessee, Steve Walker of the Y-12 Plant, and R. R. Turner of ESD who reviewed an earlier draft of this report and provided many helpful comments.

This work was funded by the Y-12 Plant Environmental Restoration Program. The Y-12 Plant and Oak Ridge National Laboratory are managed by Martin Marietta Energy Systems, Inc., under contract DE-AC05-84OR21400 with the U.S. Department of Energy. 


\section{EXECUTTVE SUMMARY}

The 1984 Hazardous and Solid Waste Amendments to the Resource Conservation and Recovery Act (RCRA) required assessment of all current and former solid waste management units. Such a RCRA Facility Investigation (RFI) was required of the Y-12 Plant for their Filled Coal Ash Pond on McCoy Branch. Because the disposal of coal ash in the ash pond, McCoy Branch, and Rogers Quarry was not consistent with the Tennessee Water Quality Act, several remediation steps were implemented or planned for McCoy Branch to address disposal problems.

The McCoy Branch RFI plan included provisions for biological monitoring of the McCoy Branch watershed. The objectives of the biological monitoring were to: (1) document changes in biological quality of McCoy Branch after completion of a pipeline and after termination of all discharges to Rogers Quarry, (2) provide guidance on the need for additional remediation, and (3) evaluate the effectiveness of implemented remedial actions. The data from the biological monitoring program will also determine if the classified uses, as identified by the State of Tennessee, of McCoy Branch are being protected and maintained.

\section{BACKGROUND}

In connection with the coal ash disposal, McCoy Branch has been segmented into four basic areas: (1) the headwater sections of McCoy Branch and a large coal ash pond created by a $19-\mathrm{m}$ earthen dam; (2) a section of free-flowing stream that flows from under the dam into Rogers Quarry; (3) Rogers Quarry, a deep, steep-sided lake; and (4) a section of free-flowing stream that flows from Rogers Quarry into Melton Hill Reservoir, with an associated embayment area. Prior to May 1990, the major source of water for McCoy Branch was the coal-ash slurry pumped from the Y-12 Steam Plant. Initially (1955), the slurry was piped to the upper reaches and was contained behind the earthen dam. As the area behind the dam filled in (1965), the slurry was transferred by overflow to Rogers Quarry; at first through McCoy Branch and then in 1989 via a pipeline. Four measures were initiated in 1986 to reduce the volume of coal ash discharged to Rogers Quarry: (1) the Y-12 Steam Plant switched to a higher grade of washed coal; (2) the Steam Plant was converted to use natural gas as the primary fuel type in the winter of 1988; (3) a dry ash handling system was installed to collect fly ash in May 1990, after which, fly ash was no longer discharged to Rogers Quarry; and (4) the Steam Plant is scheduled to install a bottom ash dewatering system in 1993, at which time all discharges to Rogers Quarry will cease.

\section{WATER QUALITY}

In 1986, coal ash slurry discharged from the Y-12 Steam Plant was found to contain elevated amounts of aluminum, barium, boron, calcium, iron, magnesium, sodium, arsenic, strontium, potassium, total suspended solids, total phosphorous, sulfide, and sulfate when compared to background water concentrations. A comparison of water quality data from 
Rogers Quarry to data for the effiuents from 14 ash ponds associated with TVA coal-fired power plants revealed that Rogers Quarry effluent was similar to effluent from other coal ash disposal ponds in the Tennessee Valley. Water quality data collected from a National Pollutant Discharge Elimination System site below Rogers Quarry show a decrease in mean weekly levels of sulfate, arsenic, and selenium after the Y-12 Steam Plant converted from coal to natural gas as the primary fuel source.

\section{TOXICITY TESTING}

The results of the toxicity tests of water from McCoy Branch did not show much evidence for toxic conditions in this stream. In 7-d laboratory tests, survival and growth of fathead minnow larvae and survival and fecundity of Ceriodaphnia were generally high, although a few exceptions to this trend were evident. Similarly, in full life-cycle tests, Ceriodaphnia had significantly fewer broods and a slightly lower mean daily fecundity in McCoy Branch water than they did in the controls, but the number of neonates per brood tended to be greater than that in controls. Thus, the net effect of McCoy Branch water on Ceriodaphnia fecundity was small. In the in situ tests, snails apparently experienced more stress in McCoy Branch at McCoy Branch kilometer (MCK) 1.60 (below Rogers Quarry) than they did at either MCK 1.'2 (above Rogers Quarry) or at White Oak Creek kilometer (WCK) 6.3 (reference stream). At MCK 1.60, the net movement of snails was downstream; whereas, the net movement of the snails at the other two sites was upstream. Typically, upstream movement of snails occurs in noncontaminated streams, and the net movement is downstream in contaminated streams. Snails may actively move downstream as an escape behavior or may be passively transported downstream by flow. In 7-d laboratory tests, snails consumed less food when tested in water from McCoy Branch at MCK 1.60) than they did in water from either MCK 1.92 or WCK 6.3, but this difference was not statistically significant. The results of associated chemical analyses also suggest the stream is not highly perturbed.

\section{BIOACCUMULATION STUDIES}

Concentrations of selenium, arsenic, and possibly thallium are elevated in largemouth bass from Rogers Quarry relative to bass from Melton Hill Reservoir and sunfish from Hinds Creek. Levels of selenium and possibly arsenic appcared to be elevated above background in bass from McCoy Branch embayment of Melton Hill Reservoir. Only arsenic exceeds conservatively based screening criteria; however, virtually all biological materials exceed this criterion for arsenic. Cessation of inputs of fly ash to the system, coupled with the rapid biological turnover of selenium and arsenic, should result in continuing decreases in concentrations of these elements in fish. The very low concentrations of mercury in fish from Rogers Quarry are consistent with findings of other research on interaction between selenium and the bioaccumulation of mercury, and suggest research areas for possible remediation of local mercury-contaminated systems. Some fish from Rogers Quarry had deformed bony structures. These effects were not described in literature on effects of selenium or arsenic; although the age of the fish indicated they were exposed in the period of higher concentrations. Bioaccumulation of organic contaminants was not indicated in the McCoy Branch discharge. 


\section{FISH COMMUNITY ASSESSMENT}

The fish community of McCoy Branch was evaluated using qualitative samples above Rogers Quarry and quantitative samples below Rogers Quarry at MCK 1.56. Electrofishing samples were made in May 1989, October 1989, and May 1990 to provide population estimates. Results from the fish assessments indicate that McCoy Branch was under severe stress. No fish populations were found above the quarry. This suggests past ash disposal practices were lethal to fish; current conditions could not be evaluated because repopulation of this section of McCoy Branch is prevented by Rogers Quarry. The community below Rogers Quarry, although permanent, appears stressed and greatly influenced by the proximity to Melton Hill Reservoir. The species composition is not typical for a small stream, and those species that inhabit the stream are generally more tolerant of degraded conditions. Additionally, abnormalities such as deformed heads and eroded fins that are typically infrequent in a normal stream population occur in a substantial percentage of the sunfish population. These deformities are the same types that were reported by the bioaccumulation studies.

\section{BENTHIC MACROINVERTEBRATE COMMUNITY ASSESSMENT}

The structure and composition of the benthic macroinvertebrate community in McCoy Branch are indicative of moderate stress. Maximunt impact within this stream occurs upstream of Rogers Quarry as is exemplified by MCK 2.03. At MCK 2.03, substantial increases were observed in density, biomass, taxonomic richness, and Ephemeroptera, Plecoptera, and Trichoptera (EPT) richness during the October and January sampling periods compared with April and July sampling, which suggests water quality improvement, but may also reflect seasonal impacts. Rogers Quarry acts as a settling basin for coal ash and reduces the impact of ash deposition on the benthic community downstream of the quarry. Although Rogers Quarry appears to reduce these impacts, it may also alter the physical and chemical environment downstream, which in turn alters the invertebrate community. Some improvement in water quality was evident downstream of the quarry, as demonstrated by significantly higher density and biomass at MCK 1.40. However, taxonomic richness, EPT richness, and diversity were significantly lower at this site, compared to the reference site, indicating that the invertebrate community was impacted. The benthic community at MCK 1.40 did not exhibit the temporal increases in density, biomass, or taxonomic and EPT richness shown by MCK 2.03, indicating this community is not experiencing similar changes in water quality. The stress on the benthic macroinvertebrate community in McCoy Branch appears to be habitat alteration as a result of ash deposition within the stream channel and possibly leaching of potential loxicants (c.g., arsenic and selenium) from the ash. As stresses to McCoy Branch are further reduced or eliminated, a steady recovery of the benthic fauna at MCK 2.03 should occur; however, the recovery at MCK 2.03 may be slowed by the loss of supplemental toow to McCoy Branch. 


\section{FUTURE STUDIES}

Quarterly ambient toxicity tests will continue at MCK 1.60 and MCK 1.92 to monitor changes in water quality. Snail release studies are planned to determine whether snails can survive and grow in upper McCoy Branch. Largemouth bass from Rogers Quarry and McCoy Branch embayment will be sampled and analyzed to determine whether metal concentrations decrease as expected. A more detailed investigation of bony structure deformities will also be conducted. Fish populations will bu surveyed at MCK 1.56 twice a year, with qualitative surveys conducted annually in upper McCoy Branch. An additional reference site will be added for comparison with the fish community data and additional qualitative surveys will be made to assess immigration potential. Long-term plans will be made to reintroduce fish into upper McCoy Branch. Benthic communities will continue to be sampled quarterly at the current sites, and an additional reference site will be added to evaluate differences related to the absence or presence of snails. 


\section{INTRODUCTION}

The 1984 Hazardous and Solid Waste Amendments to the Resource Conservation and Recovery Act (RCRA) required assessment of all current and former solid waste management units. Such an assessment or RCRA Facility Investigation (RFI) was required of the Y-12 Plant for their Filled Coal Ash Pond (Murphy 1988). The Filled Coal Ash Pond (referred to as the "ash pond" in this report) was constructed in the 1950) on the upper portion of the McCoy Branch watershed. It received coal ash through a pipeline in a slurry from the coal-fired steam plant at Y-12. Because disposal of coal ash in the ash pond, and later in McCoy Branch and Rogers Quarry, was not consistent with the Tennessee Water Quality Act, several remediation steps (e.g., extending pipeline to Rogers Quarry) were implemented or planned for McCoy Branch to address disposal problems. The initial RFI plan examined the ash pond (Murphy 1988) and associated disposal concerns. An expanded RFI plan was also written to assess remediation in McCoy Branch and some downstream components of this waste management unit (e.g., Rogers Quarry) (Murphy and Loar 1988).

The McCoy Branch RFI plan included provisions for biological monitoring of the McCoy Branch watershed. The objectives of the biological monitoring were to:

"(1) document the degree of improvement in biological quality of McCoy Branch after completion of the pipeline and after all ash discharges to Rogers Quarry are terminated; (2) provide guidance on the need for additional remediation; and (3) evaluate the effectiveness of the remedial actions that are implemented. The data from the biological monitoring program will also be sufficient to determine if the classified uses of McCoy Branch, as identified in the State of Tennessee Water Quality Management Plan for the Clinch River Basin (TDPH 1978), are being adequately protected and maintained" (Murphy and Loar 1988).

The overall strategy for the biological assessment was based on four considerations: (1) Because remediation efforts are phased temporally, the biological monitoring would also be implemented in stages with iizcreased monitoring as the system recovered. (2) The size of the stream restricted the application of assessment techniques to certain areas. (3) The fauna of McCoy Branch appeared depauperate; therefore, some constraints were necessary on the parameters to be neasured, and the need was recognized for a limited number of reference sites. and (4) Because the time frame for reaching hydrologic equilibrium following remediation is urknown, the biological monitoring must consider changes in hydrologic regime and improvement in water quality (Murphy and Loar 1988). Therefore, to address these consids rations, the biological monitoring applied to McCoy Branch consisted of an integrated multitiered program. The program included four primary tasks: (1) toxicity monitoring, (2) bioaccumulation assessments, (3) fish community assessments, and (4) benthic community assessments.

The initial results of these lour lasks are presented in this report. The results focus on the period from 1989 10 1990), but some previous data from 1974 to 1989 are also presented. 


\section{DESCRIPTION OF 'THE MCCOY BRANCH WATERSHED}

The McCoy Branch watershed is located south of the Y-12 Plant (Fig. 2-1) within the Department of Energy's (DOE) Oak Ridge Reservation (ORR). The ORR is located in the Valley and Ridge physiographic province, which is characterized by southwestnortheast oriented, parallel ridges of sandstone, shale, and cherty dolomite, separated by valleys of less resistant limestone and shale (Murphy 1988). The watershed drains Fanny's Knob on the southern slope of Chestnut Ridge and supplies water to Melton Hill Reservoir. Land use in the watershed includes grass covered slopes and fields, selected marshy pockets in the floodplain, agricultural buildings, roads, and heavily forested slopes.

The eastern branch of McCoy Branch has been extensively modified for coal ash disposal purposes. (This report will deal only with the eastern branch.) In connection with the coal ash disposal, McCoy Branch (Fig. 2-2) has been segmented into four basic areas (1) the headwater sections of McCoy Branch and a large coal filled ash pond created by a 19-m high earthen dam; (2) a section of free-flowing stream that flows from under the dam into Rogers Quarry and that, after rain, is supplemented by flow over the top of the dam; (3) Rogers Quarry, a deep, stecp-sided lake; and (4) a section of free-flowing stream that flows from Rogers Quarry into Melton Hill Reservoir, with an associated embayment area. The western branch of McCoy Branch also enters this embayment.

The headwaters of McCoy Branch consist of two intermittent streams with minimal discharge (Turner et al. 1986). A large pipe that was used to transfer coal ash slurry from Y-12 to the ash pond is located between these two streams. In the past, the flow from these three sources combined in the ash pond, which contains the ash slurry from the early years of disposal. The channel in the pond was shallow and meandered over the surface of the ash to the earthen dam. During ash sluicing and high storm runoff, flows reached the dam and were transported downstream via the overflow spillway on the eastern side of the dam.

Water in McCoy Branch below the dam derives primarily from several large springs. The spring at the base of the dam is heavily vegetated and is fed by groundwater discharges. From the dam the stream flows approximately $0.9 \mathrm{~km}$ to Rogers Quarry and is typically narrow (about 0.5 to $2.0 \mathrm{~m}$ in width) and fast-flowing, consisting of a series of runs and riffles. Just above Rogers Quarry lies a marshy area with a large spring between McCoy Branch (to the east) and the municipal sludge farm to the west. This is where McCoy Branch flowed before being diverted to fill Rogers Quarry (Murphy and Loar 1988).

Rogers Quarry is a 4-hectare lake located about midway in McCoy Branch. It was used as a source of stone in the 1940s and was abandoned when it began to fill with water in the 1950s (Bogle and Turner 1989). After leaving Roggers Quarry the stream flows through Bethel Valley, to the McCoy Branch Embayment on the Melton Hill Reservoir. The stream below the quarry is heavily vegetated and also receives flow from several spring-fed tributaries. 


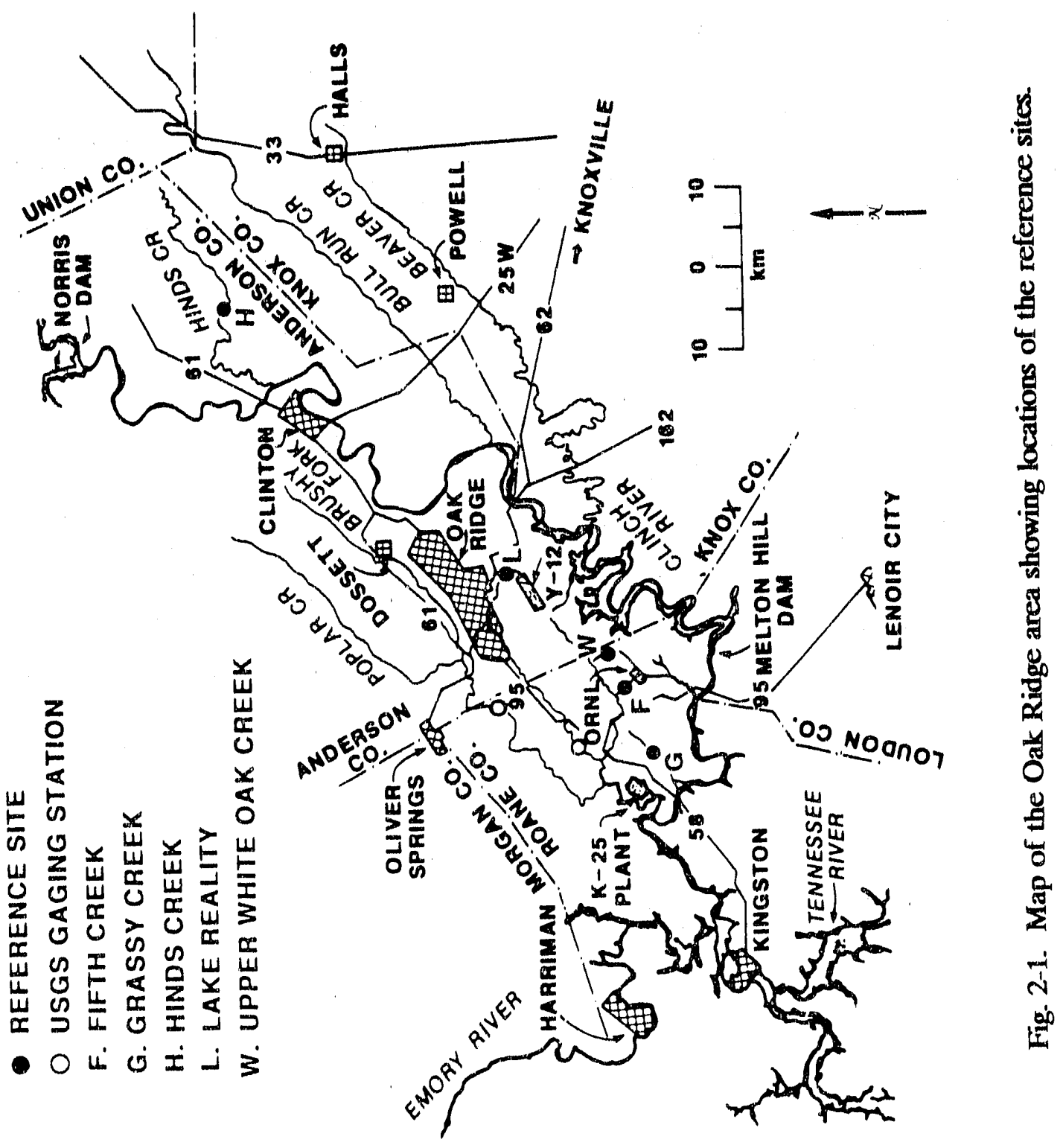


ORNL. DWG $91 \mathrm{MH}-1939$
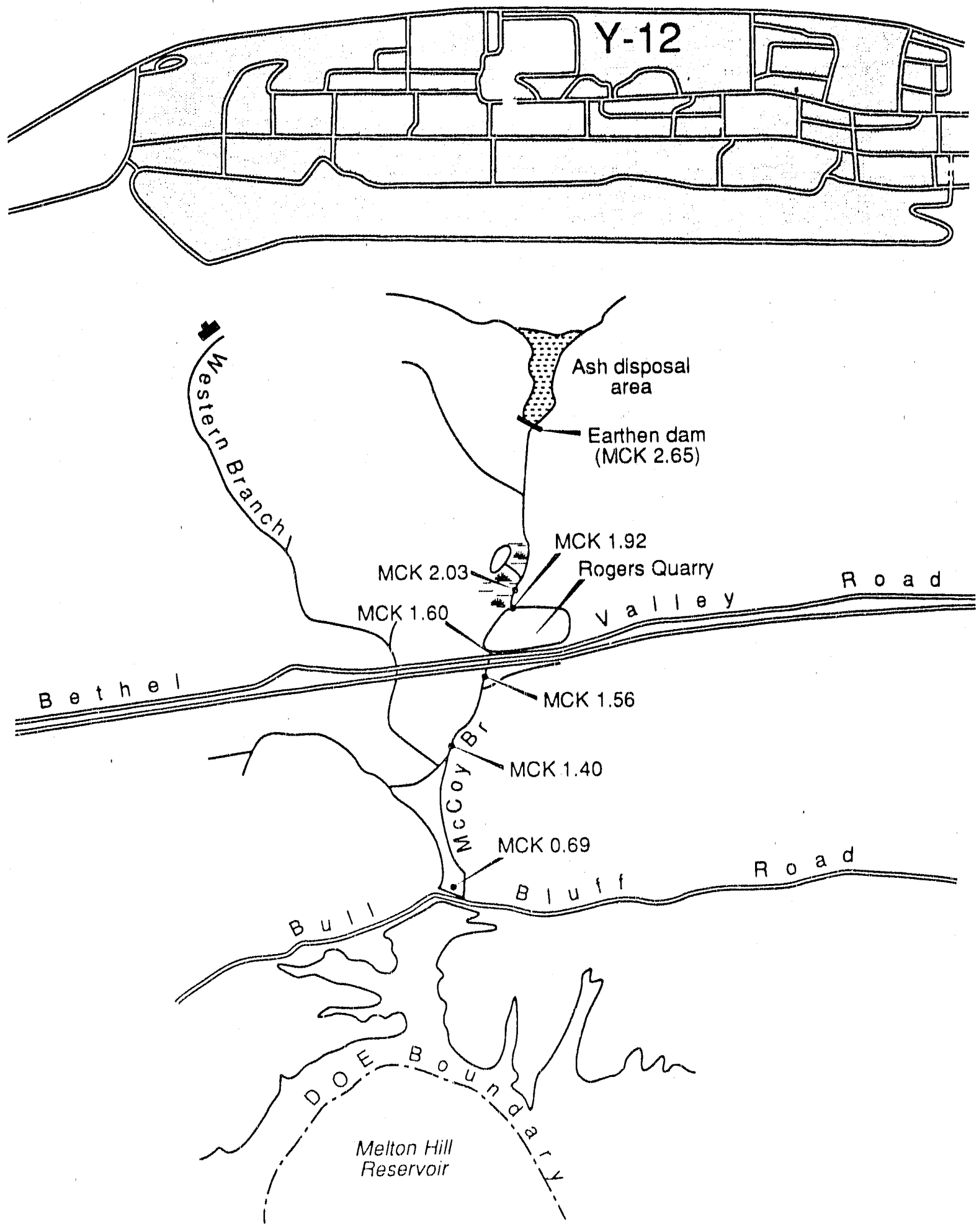

Fig. 2-2. Map of the McCoy Branch showing the primary features and monitoring siles. 
McCoy Branch is geographically separated from the Y-12 Plant by Chestnut Ridge. The distance from the ash slurry pipe on top of the ridge to the discharge into Melton Hill Reservoir is approximately $1.5 \mathrm{~km}$. The elevation at the ash slurry pipe at the top of the ridge is about $335 \mathrm{~m}$; elevation at the point where McCoy Branch discharges into Melton Hill Reservoir is approximately $244 \mathrm{~m}$. The watershed has a drainage area of about 148 hectares above Rogers Quarry, 63 ha of which lie above the earthen dam located in the headwaters.

\subsection{GEOHYDROLOGY}

McCoy Branch is underlain by the Knox group, a highly crystalline dolomite interbedded with shale and mudstone beds, a few very thin sandstone beds, aphanitic limestone lenses, numerous calcite and quartz filled fractures and cavities, and chert beds and nodules (Murphy 1988). Ketelle and Huff (1984) found that water novement in the bedrock of the Knox Group on Chestnut Ridge is controlled by the location and orientation of the cavities. Primary orientation of cavity systems are controlled by the local bedding orientation and orientation of penetrative joints and fractures, which are widened by dissolution. The actual groundwater flow paths in the bedrock are expected to resemble trellis drainage patterns, flowing parallel to strike and diverted by shorter crossstrike channels to other strike-controlled zones or emanated in surface streams. Within both the soil and bedrock aquifers, flow is from the higher topographic areas toward the lower areas, with gradients indicating flow toward the nearest perennial surface water features (Ketelle and Huff 1984; Murphy 1988).

The major source of water for the upstream reach of McCoy Branch is spring flow and precipitation. Craig and Tschantz (1986) estimated the combined base flow of these springs to be in the range of $0.42-0.53$ million liters per day. For a more comprehensive characterization of the geology and hydrology of the ash pond see Murphy (1988), Jones and Mishu (1986), and Turner et al. (1986).

\subsection{WATER QUALITY}

Water quality of McCoy Branch has been primarily aftected by coal ash discharge. The ash sluice water was enriched with total suspended solids, sulfates, phosphorous, and various metals (Turner et al. 1986). Sluicing of the ash was intermittent, with seasonal variation in the amount of ash discharged from about 0.76 million liters per day in summer to 3.8 million liters per day in winter (Murphy 1988; Bogle and Turner 1989).

\subsubsection{Description and History of Discharges to McCoy Branch and Rogers Quarry}

Prior to May 1990, the major source of water for McCoy Branch was the coal-ash slurry pumped from the Y-12 Steam Plant. The Steam Plant, built in 1954, has undergone several renovations and upgrades including conversion to a baghouse-type fly ash collection system in 1985 (Turner et al. 1986). The plant consists of four boiler units that used pulverized coal as the sole fuel source from 1954 to 1988. In the winter of 1988, the plant was converted to use natural gas as the primary fucl source and coal as a secondary 
source. When burning coal, the steam plant produces two types of ash. Historically, fly ash (dry ash) generated at the Y-12 Steam Plant was removed by a wet collection system, and bottom ash (ash collected from the bottom of the boiler in wet form) was removed by high pressure water jets. The ash was then sluiced (pumped) in series: first the fly ash and then the bottom ash, as a slurry over the crest of Chestnut Ridge. Gravity flow carried the effluent to the ash pond, a broad earthen retention basin of about 8 hectares, which provided sedimentation for the ash slurry before discharge into McCoy Branch (Turner et al. 1986; M. A. Kane, Y-12 Plant, personal communication). The pond was expected to hold 20 years of Y-12 Steam Plant ash, but was filled to within almost $1 \mathrm{~m}$ of the top of the dam by July 1967 (Murphy 1988). Subsequently, flow from McCoy Branch was used to channel the slurry to Rogers Quarry. Since 1962, Rogers Quarry has been used for the disposal of ash slurry from the Y.12 Plant. However, between 1965 and 1981 the quarry was also used for the disposal of weapons related and classified items (Table 5 in McCauley 1986; Bogle and Turner 1989). For a complete description of Rogers Quarry see Bogle and Turner (1989). In November 1989, ash slurry discharge to the upper reaches of McCoy Branch was terminated by extending the pipeline directly to Rogers Quarry, which has an estimated life expectancy for ash disposal of 65 to 115 years (Murphy 1988; M. A. Kane, Y-12 Plant, personal communication).

Discharges into McCoy Branch and Rogers Quarry are in violation of the Tennessee Water Quality Act. Several interim actions have taken place, or are anticipated, to assure compliance by July 1, 1993, when all discharges to Rogers Quarry must be terminated (Murphy and Loar 1988). Four measures were initiated in 1986 to reduce the volume of coal ash discharged to Rogers Quarry. (1) The Y.12 Steam Plant switched to a higher grade of washed coal, increasing efficiency and decreasing the total volume of coal utilized in 1986. (2) The Steam Plant was converted in the winter of 1988 to use natural gas as the primary fuel type. The targeted yearly ratio of energy derived from gas compared to that from coal is approximately 5 to 1 , with a higher pereentage of coal being used in winter months. (3) A dry vacuum system was installed in May 1990 to collect dry fly ash. Fly ash is now put in a landfill, and all fly ash sluice water discharge to Rogers Quarry has been terminated. (4) Present discharges to Rogers Quarry include only bottom ash sluice water and steam plant washdown water. The Y-12 Steam Plant is scheduled to install a bottom ash dewatering system in 1993, at which time bottom ash will be landfilled and washdown water will be processed through the Steam Plant's wastewater treatment facility.

\subsubsection{Characterization of the Contaminant Source}

In a study by Pulliam (1985a,b) water upstream from Rogers Quarry had higher levels of most metals than did water samples taken downstream of Rogers Quarry (Appendix A, Table A-1). These data were supported by results in ERDA 1975 (Appendix A, Table A-2). In a study by Turner et al. (1986), coal ash sluice water discharged from the Y-12 Steam Plant was found to contain elevated amounts of aluminum, barium, boron, calcium, iron, magnesium, sodium, arsenic, strontium, potassium, total suspended solids, total phosphorous, sulfide, and sulfate when compared to background water

concentrations (Appendix A, Tables A-3, A-4, A-5, and A-6). Turner et al. (1986) also noted that the filled ash pond provided little or no treatment, did not remove suspended solids, and the flow of McCoy Branch was so small that it was incapable of providing appreciable dilution to the ash sluice water. Turner et al. (1986) also compared water 
quality data from Rogers Quarry to data for the effluents lrom 14 ash ponds associated with Tennessee Valley Authority (TVA) coal-fired power plants. The comparison revealed that Rogers Quarry effluent was similar to effluent from other ash disposal ponds in the Tennessee Valley. Notable differences included higher concentrations of total phosphorous and arsenic, and lower concentrations of aluminum and iron, than in effluent from the TVA ash ponds. Turner et al. (1986) also reported that nearly all organic compounds were below analytical detection limits in all samples.

As part of the secent RFI for McCoy Branch, more surface water quality data were taken from McCoy Branch during dry weather (July 30, 1990) and during wet weather (after a 4.5-cm rain event) on October 8, 1990 (Appendix A, Tabies A.\% to A-13). Under both conditions, lower levels of sulfate, selenium, and arsenic were seen in comparison with historical water quality data measured when the slurry was being discharged to upper McCoy Branch. More substantial decreases were seen in levels of suspended solids and lead, but increased levels of magnesium and potassium were also noted. Values for most volatile and semivolatile organic compounds in surface water were below detection limits.

Water quality data collected from a National Pollutant Discharge Elimination System (NPDES) site below Rogers Quarry (Outfall 302) show a decrease in mean weekly levels of sulfate, arsenic, and selenium (Table 2-1 and Figures 2-3, 2-4, and 2-5) after the Y-12 Steam Plant converted from coal to natural gas as the primary fuel source (R. R. Turner, Environmental Sciences Division, ORNL, personal communication). At the time of publication, there are no water quality data available for current ash sluice discharges into Rogers Quarry. Recent data collected by the Off-site Environmental Restoration Program indicate a peak in arsenic levels below the discharge from Rogers Quarry and exhibit a dilution effect downstream in McCoy Branch embayment (Table 2-2).

\subsubsection{Temperature}

Temperature data for McCoy Branch before December 1989 are limited. Turner et al. (1986) reported that ash sluicing did not appear to affect temperatures in McCoy Branch, presumably because untreated (except for chlorination) Clinch River water was used for sluicing. Current temperature data show little difference between temperatures in McCoy Branch above Rogers Quarry, upper White Oak Creek (WOC), and upper Fifth Creek (Table A-14 and Figure 2-6). Mean weekly temperatures in McCoy Branch below Rogers Quarry are similar to reference streams in winter but up to $10^{\circ} \mathrm{C}$ higher in summer months. Elevated summer temperatures may be explained by thermal layering in, and epilimnetic discharges from, Rogers Quarry.

\subsubsection{Sediments and Groundwater}

Ash deposits, which occurred when the creek's flow overtopped its banks, vary greatly along the stream. In a preliminary study, Murphy (1988) found that immediately downstream of the ash pond dam, the deposits cover the entire valley through which MeCoy Branch flows. Further downstream, the deposits are limited to no more than a couple of meters horizontally from the edge of the creck. 


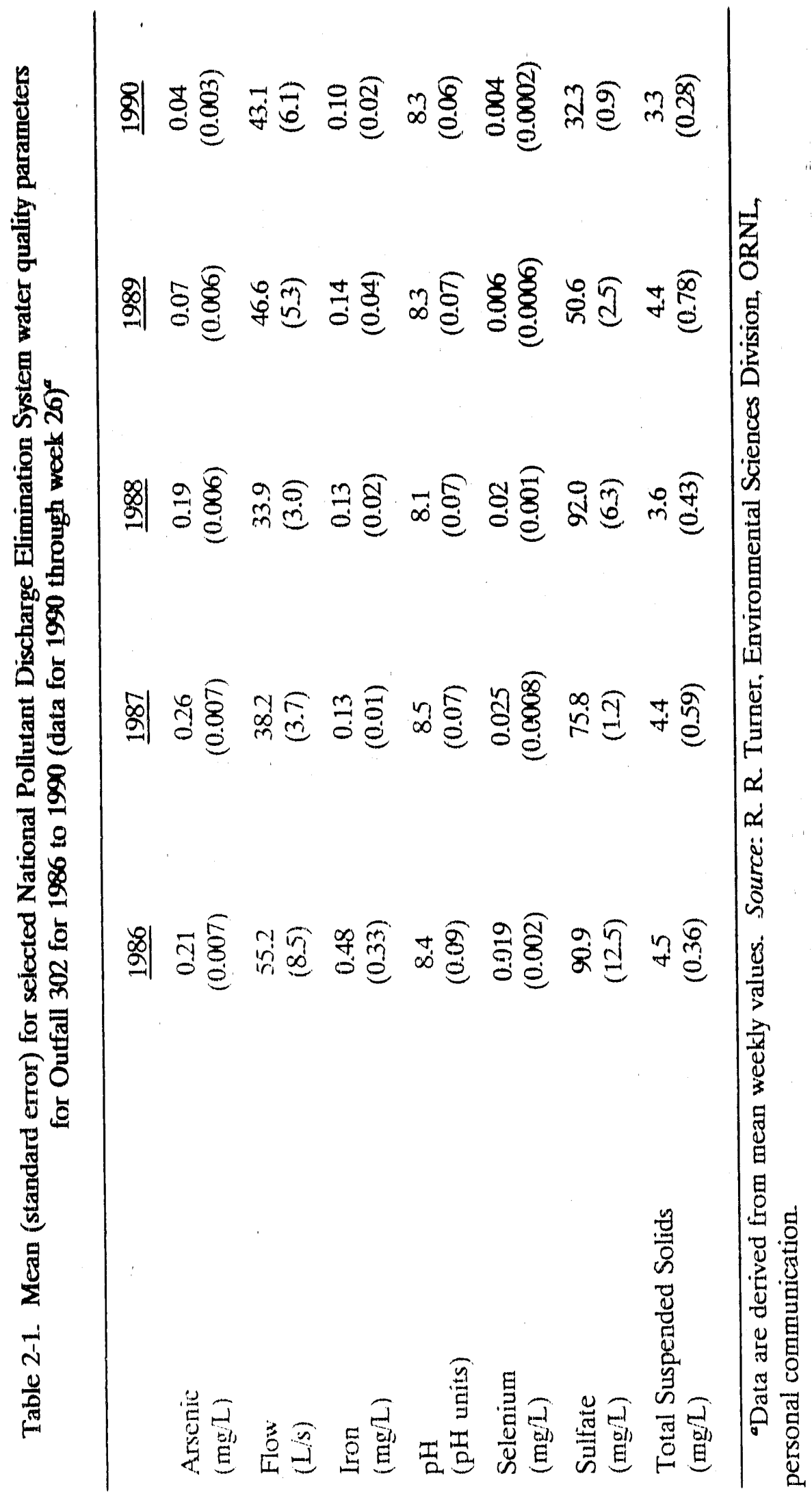




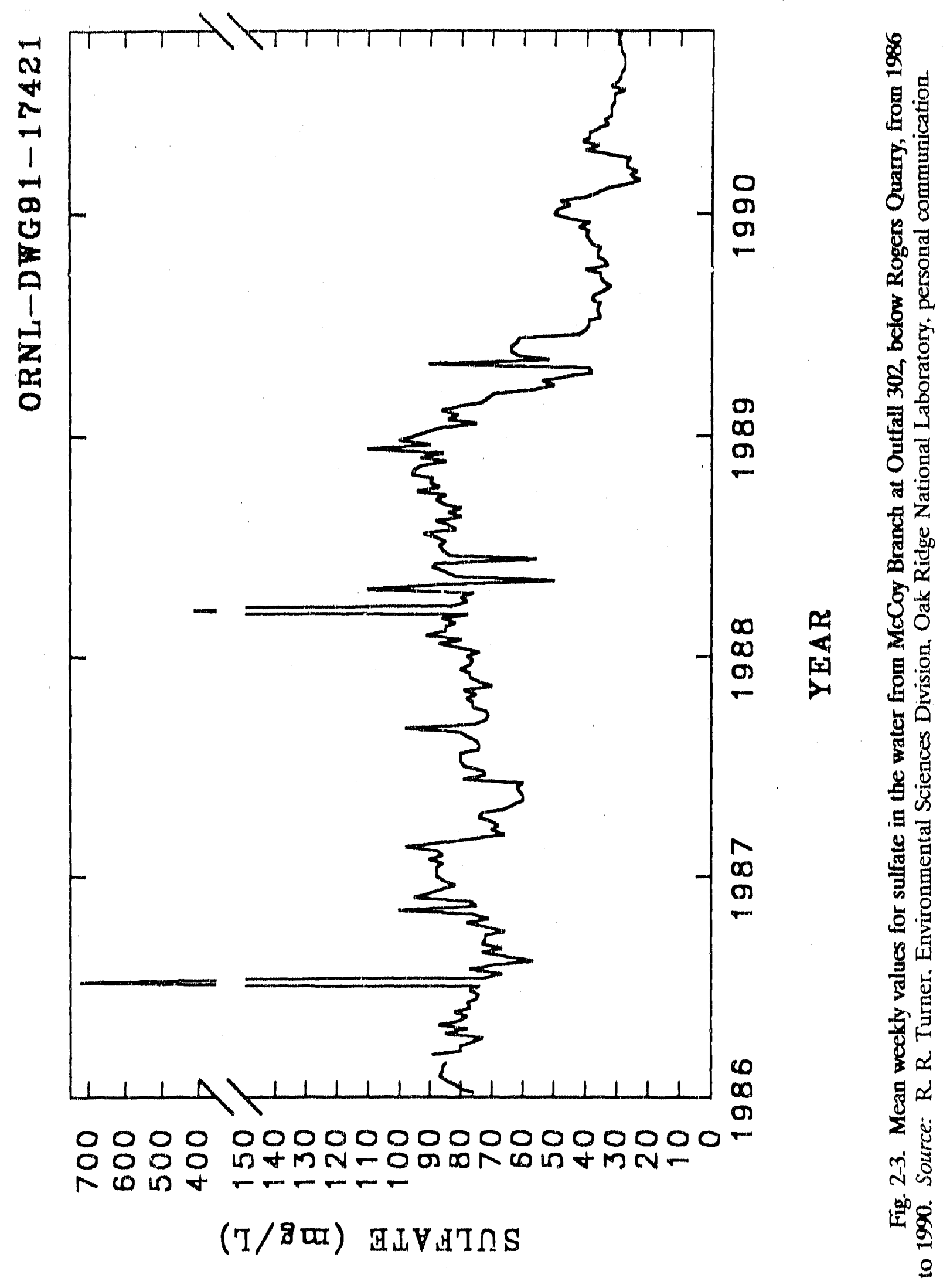




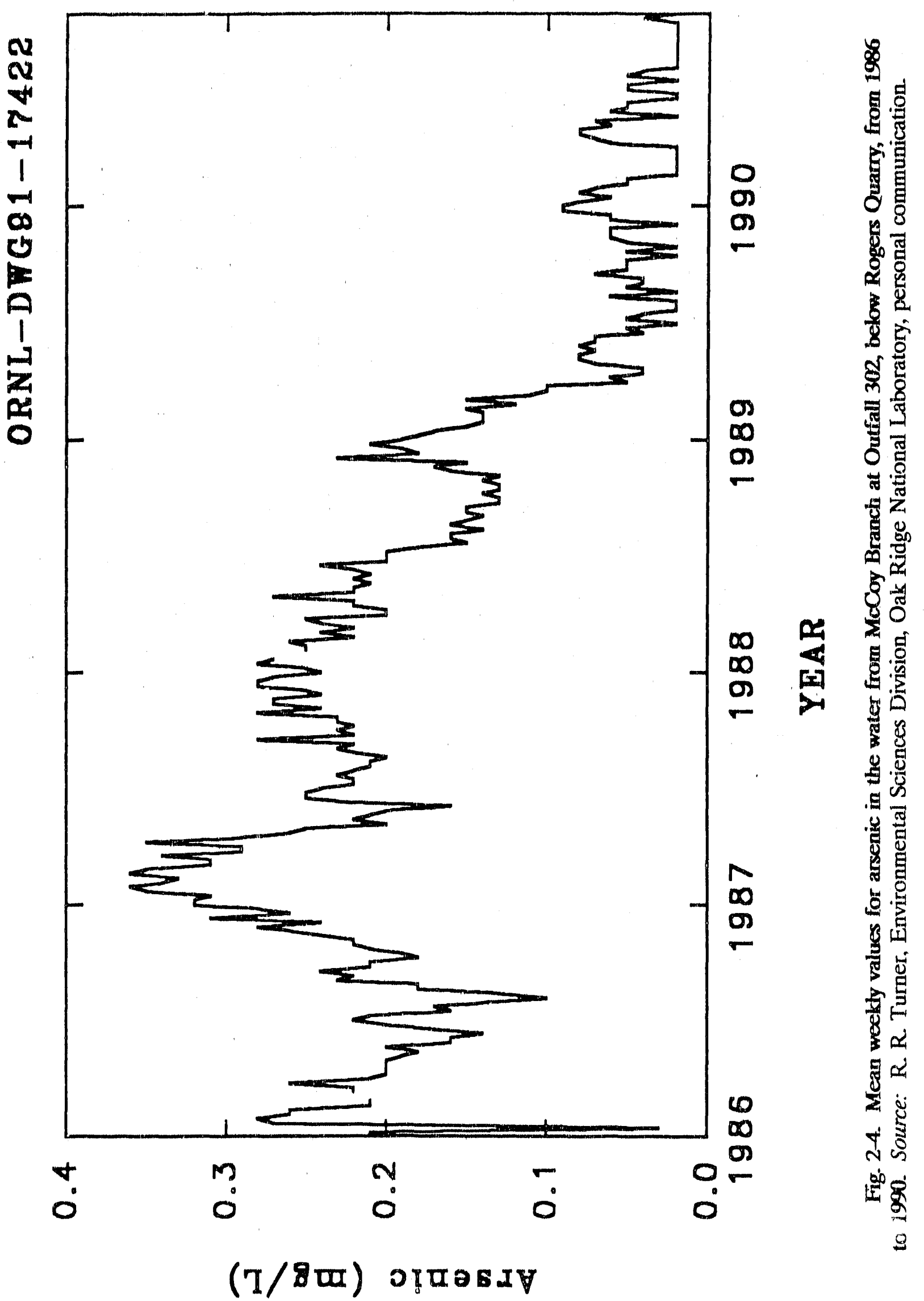


$2-10$

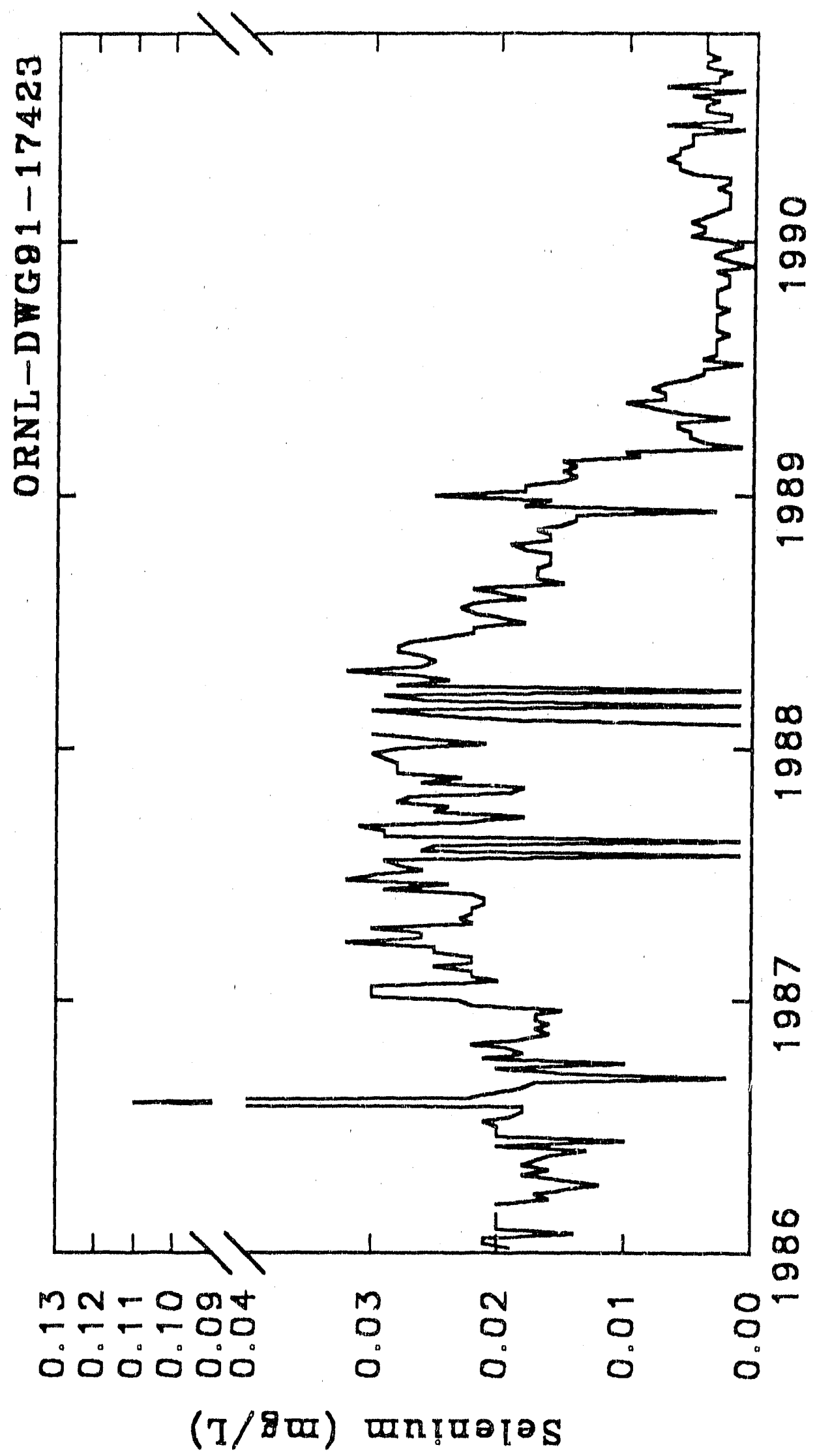

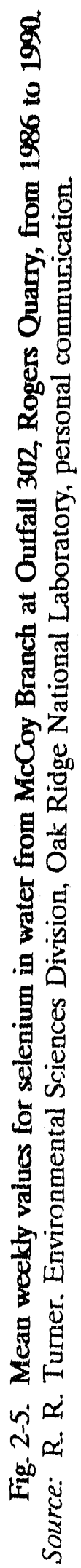


Table 2-2. Arsenic levels in McCoy Branch on March 15, 1990\%

\begin{tabular}{llc}
\hline Station & \multicolumn{1}{c}{ Location } & $\begin{array}{c}\text { Total As } \\
(\mu \mathrm{g} / \mathrm{L})\end{array}$ \\
\hline MCK 1.92 & Weir above Rogers Quarry & 2.9 \\
MCK 1.71 & Below Rogers Quarry & 29.5 \\
MCK 0.69 & Upstream of culvert & 5.3 \\
MCK 0.65 & Downstream of culvert & 1.2 \\
MCK 0.30 & McCoy Branch Embayment & 0.05 \\
\hline
\end{tabular}

${ }^{a}$ Data collected by the Off-site Environmental Restoration Program, Clinch River Rernedial Investigation. Source: James T. Byrd, Skidway Institute of Oceanography, Savannah Georgia, personal communication. 


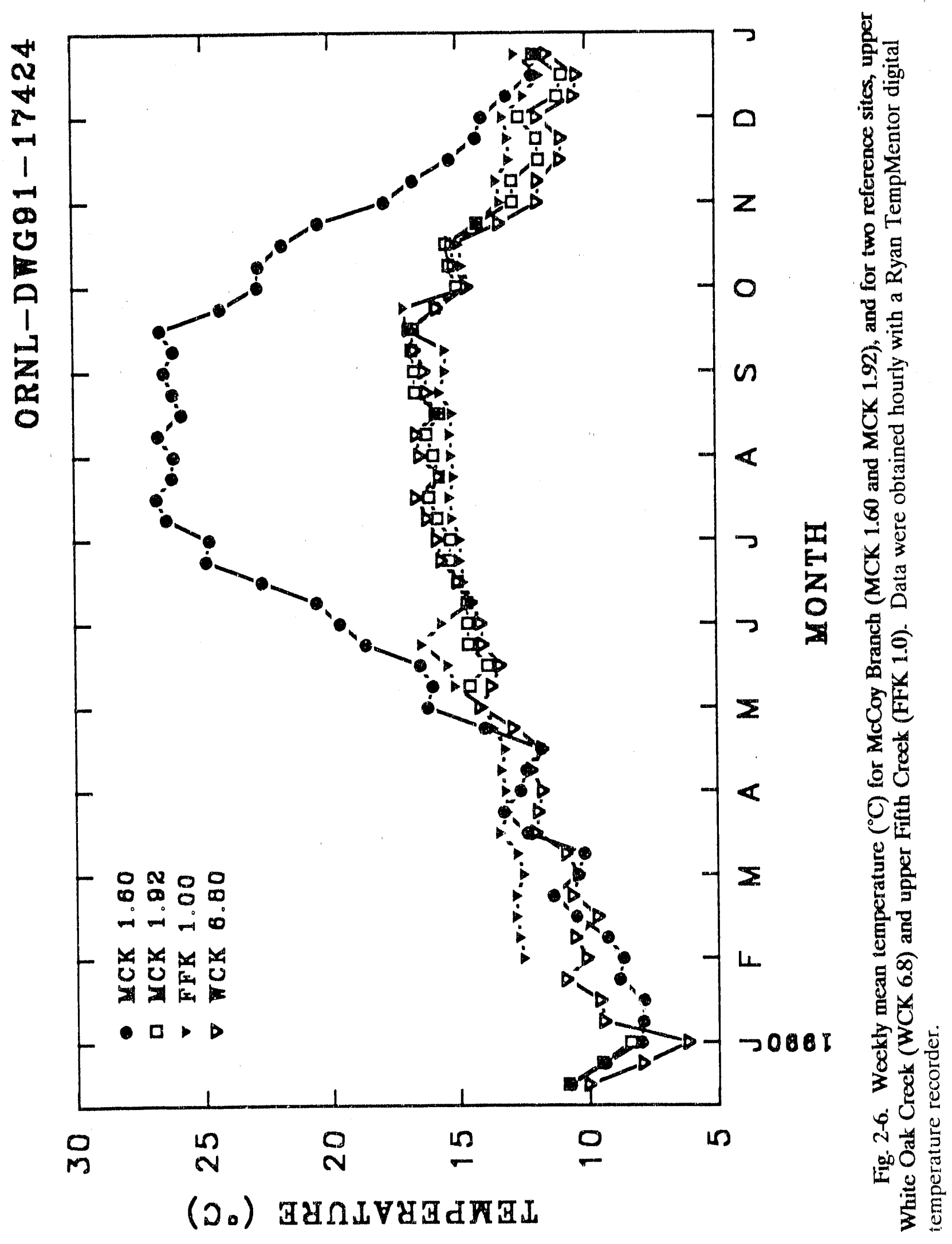


Sediment analysis for McCoy Branch from 1974 to 1975 (ERDA 1975) showed elevated levels of some metals (Appendix A, Table A-15). In accordance with the RCRA Facilities Investigation (RFI), an assessment is being conducted of the impact that coal ash deposits may have had in the area immediately adjacent to McCoy Branch (Murphy 1988). Phase I of the assessment will be to determine the extent, both horizontal and vertical, of coal ash deposits in the McCoy Branch floodplain from the point of discharge at the dam to the point of discharge of McCoy Branch into Rogers Quarry. Phase II will include sampling the ash and underlying soil to determine the extent contaminants from the coal may have migrated into the soil. For a more detailed description of the methodology for the sediment analysis see Murphy (1988). Initial analyses of these ash and sediment samples collected during 1990 from McCoy Branch show elevated levels of $\mathrm{Cd}, \mathrm{Mn}, \mathrm{Ba}$, $\mathrm{Ca}, \mathrm{Fe}, \mathrm{K}, \mathrm{Mg}, \mathrm{Na}$, and $\mathrm{Ni}$ (Appendix A, Tables A-16 and A-17) compared to data collected in 1974-1985 (Table A-15). The only analyzed elements occasionally falling below detection limits were niohium and selenium. Levels of oil and grease were $<0.1 \%$ for all sediment sites. Levels of radioactivity for each site are given in Appendix A, Table A-18.

Coal ashes typically exhibit leachability of ash constituents. Groundwater may be a receptor of contaminants from the coal ash disposal system and may act as a pathway for contamination migration near the Y-12 Plant (Murphy 1988). Groundwater sampled in October 1987, February 1988, May 1988 (Murphy 1988, Table 7-1), and October 1990 (Appendix A, Tables A-19 and A-20) showed no evidence of contamination above regulatory standards or above expected background. 


\section{TOXICITY MONITORING}

Biological tests can be used reliably to detect water quality problems that may not be evident with routine chemical analyses. For this reason and because remedial actions are driven ultimately by the need to protect living organisms and ecological processes from hazardous chemicals, biological tests are gaining acceptance for making regulatory decisions about water quality and environmental remediation.

To obtain data for such decisions, bioassays were used periodically to assess water from three sites in McCoy Branch. Four types of biological tests were used: (1) a series of 7-d tests with fish larvae (the fathead minnow; Pimephales promelas) and a microcrustacean (Ceriodaphnia dubia); (2) a full life-cycle test (LCT) with C. dubia; (3) an in situ test with snails (Elimia sp.); and (4) a 7-d laboratory test with Elimia sp. The methods used for each of these tests and the sites evaluated with particular tests are described in Sect. 3.1.

\subsection{MATERIALS AND METHODS}

\subsubsection{Seven-Day Toxicity Tests}

Seven-day tests with fathead minnow larvae and Ceriodaphnia are U.S. Environmental Protection Agency (EPA) approved, static-renewal bioassays; tests with these two organisms are commonly used to estimate acute and chronic toxicity of wastewaters and freshwater receiving systems (Weber et al. 1989). The fathead minnow test estimates toxicity by comparing survival and growth of larval fish in water samples being tested with the survival and growth of larvae in control water known to be of high biological quality. Relative to this control, reductions in fish survival or growth can be attributed to the presence of toxicants. The Ceriodaphnia test is fundamentally similar to the fathead minnow test but uses survival and fecundity, rather than survival and growth, as endpoints. The procedures used to conduct the 7-d minnow and Ceriodaphnia tests of water from McCoy Branch are given in Stewart et al. (1990) and Kszos and Stewart (1991).

This report gives the results of 7-d minnow and Ceriodaphnia tests for seven test periods; the first period started on January 5, 1989, and the last ended on August 6, 1990. In the first test period, only Ceriodaphnia was tested. In the remaining six test periods, fathead minnow larvae and Ceriodaphnia tests were conducted concurrently. The 7-d minnow and Ceriodaphnia tests were used to evaluate water from the outfall of Rogers Quarry (MCK 1.60), at the quarry's inlet (MCK 1.92), and from a spring near the base of the ash pond dam.

\subsubsection{Full Life-Cycle Tests}

The second type of bioassay consisted of Ceriodaphnia full LCTs. LCTs are considered to be more sensitive than 7-d tests because they substantially extend the exposure period, thereby providing more time for the organisms to accumulate and 
respond to materials potentially present in solution. Relative to 7-d tests, Ceriodaphnia LCTs are not used frequently in water quality assessments. LCTs are substantially more intensive and, thus, expensive than the 7-d tests; they require $35-40 \mathrm{~d}$ for completion and need more replicates (e.g., 50 versus 10) for satisfactory statistical analyses.

The procedures used in the Ceriodaphnia LCC.Ts were identical to those in the 7-d Ceriodaphnia tests, including feeding and daily renewal of test solution. However, the LCTs differed from the 7-d tests in three ways: (1) Although water samples were collected fresh daily for the 7-d tests, samples for the LCTs were collected on Tuesdays and Fridays. Between collection events, LCT water samples were stored in a refrigerator at $7^{\circ} \mathrm{C}$; however, the daily subsamples were warmed to $25 \pm 1^{\circ} \mathrm{C}$ before use. (2) LCTs evaluated only full-strength water. The 7-d tests, in contrast, employed various concentrations of McCoy Branch water; typically $100,80,60$, and $40 \%$ of full strength (Table 3-1). (3) The LCTs used 50 replicate beakers (1 neonate per beaker) for each water type, but the 7-d tests used only 10 replicates per concentration.

An LCT to evaluate water from McCoy Branch at MCK 1.92 was started on July 28 , 1990. Simultaneously, an LCT was initiated to evaluate water quality from East Fork Poplar Creek at the outfall of Lake Reality (LR-O). Water from LR-O provided a contaminated reference suitable for establishing a contrast with McCoy Branch. A set of 50 beakers eontaining diluted mineral water was included as a negative control for these two LCTs. The LCTs continued until September 5, 199) (a 40-d period), when the last animal died.

Analysis of variance (ANOVA) was used to analyze survival and reproduction data from the LCTs (SAS 1985a,b). Three sites [McCoy Branch at Rogers Quarry inlet (MCK 1.92), East Fork Poplar Creek at LR-o, and controls] yyywere included in the analysis. Seven dependent variables were inspected to determine how well their variance patterns could be attributed to site. The variables were (1) Ceriodaphnia life span (in days); (2) the total number of offspring produeed by each animal for all animals that produced any offspring; (3) the number of broods produced per female; (4) the mean number of oftspring per brood (i.e., brood size); (5) the number of offspring in the largest brood of each lemale; (6) the brood-1o-brood variability (expressed as the coefficient of variation, CV\%) in numbers of offspring produced per female; and (7) mean daily fecundity (the total number of off'spring produced by a female divided by that female's reproductive life span). Ceriodaphinia dubia neonates are not reproductively active for the first $3 \mathrm{~d}$ of their life. Thus, a female's reproductive life span was computed by subtracting 3 d from her total life span.

\subsubsection{In situ Snail Tests}

Previous studies have shown that pleurocerid snails (c.g., Elimia claveformis) tend naturally to move upstream and that this behavior can be significantly affected by the presence of contaminants (Burris et al. 1990). Based on these findings, 150 snails (E. clavaeformis) were collected from upper White Oak Creck (WCK 6.3) on July 23, 1990. Each animal was marked by placing a dot of lingernail polish on the shell. The animals were all of similar size and were acelimated, stepwise, over a 7-d period, from field temperature (about $17^{\circ} \mathrm{C}$ ) lo testing temperature $\left(25^{\circ} \mathrm{C}\right)$ before use. The snails were fed 


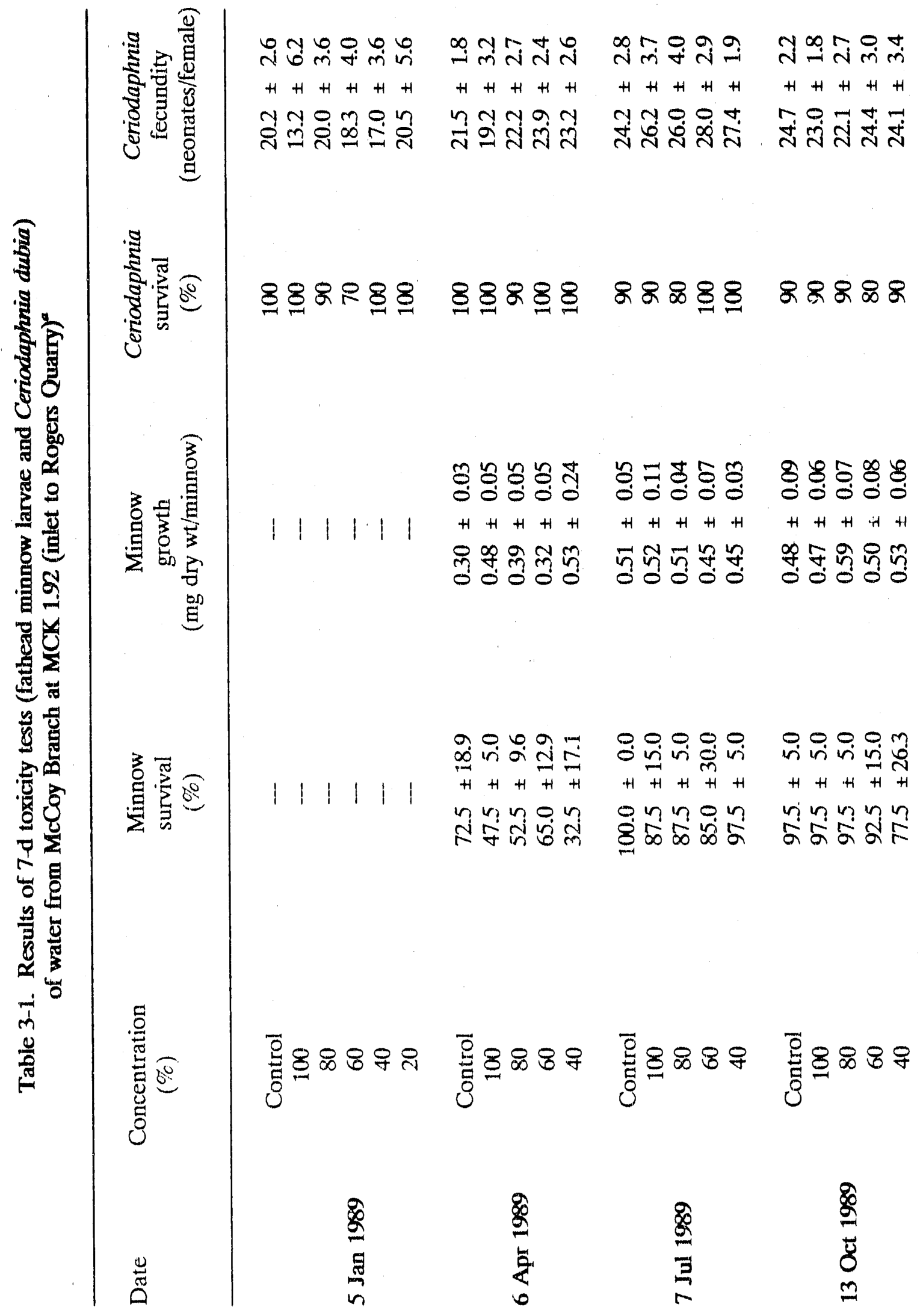




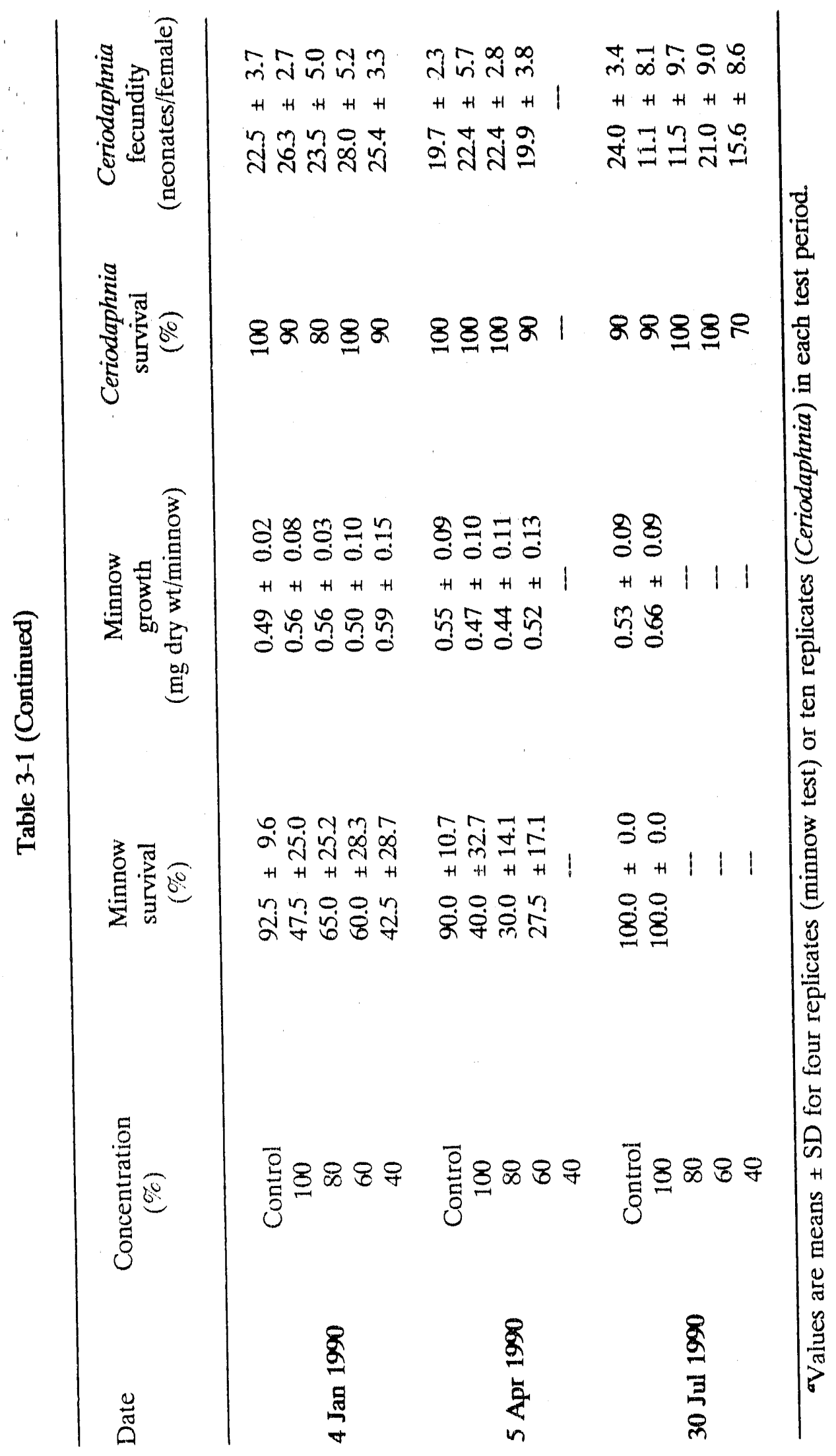


commercial lettuce leaves during the acclimation period. On July 30, 1990, 50 of the marked snails were released at each of three sites: McCoy Branch $10 \mathrm{~m}$ above Rogers Quarry (MCK 1.92), McCoy Branch at MCK 1.60) (below Kogers Quarry), and White Oak Creek at WCK 6.3. Forty-eight hours after the snails had been released, each site was surveyed for the snails. The searches were initiated $10 \mathrm{~m}$ downstream of the release point and continued upstream beyond the release point for $20 \mathrm{~m}$. The position of each marked snail, relative to the release point, was measured to the nearest centimeter. A median test for multiple samples was used to determine if the median distance the snails moved upstream differed among the three sites (Steel and Torrie 1980).

\subsubsection{Seven-Day Snail Test}

A 7-d static-renewal test with snails was used to determine if the snails' feeding rate was affected by water from two sites in McCoy Branch (MCK 1.92 and MCK 1.60). Snails were collected from WCK 6.3 on July 2.3, 1990, and acclimated as described in Sect. 3.1.3.

Test chambers consisted of 60()$-\mathrm{mL}$ beakers. Each beaker contained 12 snails and $250 \mathrm{~mL}$ of water; 4 replicate beakers were used for each treatment. Treatments consisted of full-strength water from each of three sites: McCoy Branch at MCK 1.92, McCoy Branch at MCK 1.60), and for relerence purposes, White Oak Creek at WCK 6.3. The contents of the beakers were maintained at $25 \pm 1^{\circ} \mathrm{C}$ throughout the test by a water bath. Two pre-weighed lettuce leaf dises $\left(\right.$ each $3.0 \mathrm{~cm}^{2}$ ) were added to each beaker at the start of the test. After $24 \mathrm{~h}$ and daily thereafter, the remains of the dises were removed, new discs were added, and the water was changed. The remnants of the dises taken from each beaker were blotted dry with paper towels and weighed to the nearest $0.1 \mathrm{mg}$. The difference between initial weight and final weight of the dises in each beaker was used to estimate the wet mass of lettuce leaf eaten daily by the snails in that replicate.

Differences among feeding rates among treatments were analyzed using SAS-GLM with a repeated-measures subroutine (SAS 1985a,b).

\subsubsection{Chemical Analyses of Water Quality}

A majority of water samples collected for use in any of the tests described above were analyzed chemically for pH, conductivity, alkalinity (EPA method 130.1), and hardness (EPA method 130.2). The methods used for each of these analyses are described by Ksizos el al. (1989).

During one 7-d lest period (April 5-11, 199()), water from two McCoy Branch sites (MCK 1.92 and the large spring at the base of the earthen dam) was analyzed for orthophosphate and sulliate (EPA methods 365.1 and 375.2, respectively). During another 7-d period (July 7-13, 1989), samples collected daily from McCoy Branch at MCK 1.92 were analyzed for nitrate, orthophosphate, and sulfate. 


\subsection{RESULTS}

\subsubsection{Seven-Day Toxicity Tests}

The results of the Ceriodaphnia and fathead minnow toxicity tests of water from McCoy Branch at MCK 1.92 are summarized in Table 3-1; the results of tests with these two species applied to water from McCoy Branch at MCK 1.60) and at the spring near the base of the dam at the ash pond are summarized in Table 3-2.

Overall, the 7-d tests provided little consistent evidence for toxicity to either species. On three occasions, specific problems with test conditions were suggested. First, in the test started on January 5, 1989, fecundity of Ceriodaphnia reared in water from McCoy Branch was unusually low and variable $(13.2 \pm 6.2$, mean $\pm S D)$ relative to controls $(20.2 \pm 2.6)$. The high variability in fecundity for the animals in McCoy Branch water in this test $(\mathrm{C} . \mathrm{V} .=47 \%)$ is difticult to interpret biologically. Second, the minnow test conducted during April 6-13, 1989, appeared flawed. Survival and growth rates of fish in the controls and in McCoy Branch water were both unusually low, suggesting inadequate food. Survival and reproduction of Ceriodaphnia in this test were high both for eontrols and for water from McCoy Branch. Third, survival (but not growth) of the fish was low in MeCoy Branch water in the tests that started on January 4, 1990, and April 5, 1990 (Table 3-1). During these two test periods no evidence of toxicity was detected using Ceriodaphnia. Additionally, no conspicuous relationship between fish survival and concentration of McCoy Branch water in either of these tests (Table 3-1) was detected. These considerations suggest that the 'toxicity' in McCoy Branch during each of these three test periods was probably artifactual.

\subsubsection{Full-Life Cycle Tests}

Mean values for each of the 7 dependent variables for Ceriodaphnia in each of the three water types are given in Table 3-3. The mean number of broods by Ceriodaphnia lested in McCoy Branch water was lower than that of Ceriodaphnia in the control (10.1 versus 12.4 offspring per female, Table $3-3$ ). The mean daily fecundity of Ceriodaphnia in McCoy Branch water was also substantially lower than that of eontrols (5.3 versus 6.1 offspring per female per day, Table 3-3). The overall difference in total fecundity of Ceriodaphenia in controls versus McCoy Branch water, though, was not very great (122 versus 109.3 oflspring per female, Table 3-3) because Ceriodaphnia in McCoy Branch water tended to have slightly larger broods than Ceriodaphnia in the control (10.7 versus 9.8 offspring per brood, Table $3-3$ ).

Separate sets of one-way ANOVAs were conducted to contrast reproductive patterns of Ceriodaphnia tested in MCK 1.92 to control water (Table 3-4) and water from LR-() (Table 3-5). These analyses showed that the contrast in reproductive patterns of Ceriodaphnia tested in water from MCK 1.92 versus LR-o (Table 3-4) was similar in two important respects to the eontrast between water from MCK 1.92 versus control water ('Table 3-5). First, the number of broods and the mean number of offspring per brood tended to be among the more dynamic parameters in both eomparisons, based on the magnitude of change in $p$ (about 12.3-fold for the number of broods and 8.6 -fold for the number of offspring per brood, Tables 3-4 and 3-5). The number of broods and the mean 


\section{3-7}

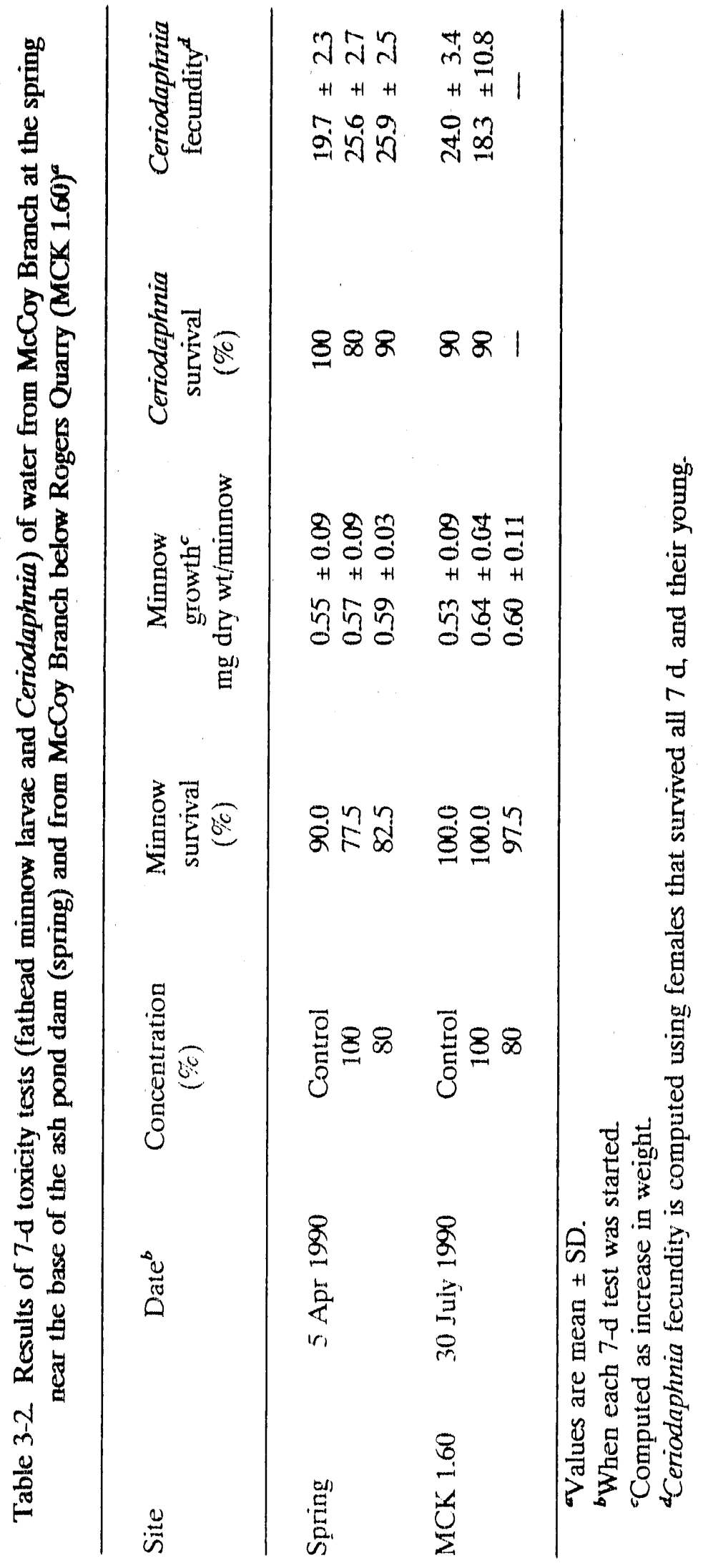


Table 3-3. Means of Ceriodaphnia survival and reproduction paramoters for life-cycles teats with control water, water from McCoy Branch at the inlet to Rogers Quarry (MCK 1.92), and water from East Fork Poplar Creok at the outfall of Lake Reality (LR-o)

\begin{tabular}{|c|c|c|c|}
\hline \multirow[b]{2}{*}{ Paramotor } & \multicolumn{3}{|c|}{ Sitc } \\
\hline & Control & $L R-()$ & MCK 1.92 \\
\hline Lilie span (days) & 23.1 & 25.6 & 24.3 \\
\hline Number of hroods & 12.4 & 9.7 & 10.1 \\
\hline No, ol' affspring/hrood & 9.8 & 12.0 & 10.7 \\
\hline Total No, of oflispring & $122,(1)$ & 114.7 & 109.3 \\
\hline Largest brosel & 17.8 & 19.7 & 18.5 \\
\hline Variability in l'ccundily & 51.7 & 51.8 & 56.2 \\
\hline Daily fecundily & 6.1 & 5.5 & 5.3 \\
\hline
\end{tabular}

Table 3-4. Analysis of variance results for Ceriodaphnia life-cycle lcats of control wator - and water from McCoy Branch at MCK $1.92^{a}$

\begin{tabular}{|c|c|c|c|c|c|}
\hline Dependent variuble & $\begin{array}{c}\text { Model } \\
\text { DF }\end{array}$ & $\begin{array}{c}\text { Error } \\
\text { DF }\end{array}$ & $\mathrm{R}^{2}$ & $F$ & P \\
\hline Lifie span & 1 & 98 & $0 .(K) 55$ & 0.54 & 0.46 .34 \\
\hline Number of broods & 1 & 96 & 0.0809 & 8.45 & $0 .(0) 4.5$ \\
\hline No, ol' offispring/broud & 1 & 96 & $0 .(1257$ & 2.54 & 0.1146 \\
\hline 'Total No, ollispring & 1 & 96 & $(0.0173$ & 1.69 & 0.1967 \\
\hline Largest brood & 1 & 96 & 0.0101 & 0.98 & $(0.3240$ \\
\hline Varriability in l'ccundily & 1 & 95 & $(0.01(\mathcal{Y C})$ & 1.93 & 0.1685 \\
\hline Daily lecundily & 1 & 97 & 0.0 .394 & 3.98 & $(1,(1) 489$ \\
\hline
\end{tabular}

"The probability (p) that the difference between means of parameters for controls versus: MeCoy Branch was clue to ehance alone is given for each parameler; the palues were oblained by onc-waly analysis of variance tests. $R^{2}$ is the proportion of the total vartation that can be explained by the diflerence in water lype. 
Tablo 3-5. Analysis of variance results for Ceriodaphnia life-cyclo tests of wator from Lake Reality outfall and McCoy Branch at MCK $1.92^{\circ}$

\begin{tabular}{lccccc} 
Dependent Vuriable & $\begin{array}{c}\text { Model } \\
\text { DF }\end{array}$ & $\begin{array}{c}\text { Error } \\
\mathrm{DF}\end{array}$ & $\mathrm{R}^{2}$ & $\mathrm{~F}$ & $\mathrm{P}$ \\
\hline Lil'e span & 1 & 98 & $0.0(0) 70$ & 0.69 & 0.4068 \\
Number of broods & 1 & 97 & 0.0036 & 0.35 & 0.5553 \\
No. of off'spring/brocid & 1 & 97 & 0.0615 & 6.35 & 0.0133 \\
Total No, offspring & 1 & 97 & 0.0054 & 0.52 & 0.4715 \\
Largest brood & 1 & 97 & 0.0351 & 3.53 & 0.0634 \\
Variability in leciundity & 1 & 96 & 0.0203 & 1.99 & 0.162 .0 \\
Daily f'ecundity & 1 & 97 & $0.0(123$ & 0.22 & 0.6366 \\
\hline
\end{tabular}

The probability $(p)$ that the difference between means of parameters for Lake Reality outfall water versus McCoy Branch water was due to chance alone is given for each parameter; the $p$ values were obtained by one-way analysis of variance tests. $\mathbf{R}^{2}$ is the propottion of the total viriation that can be explained by the difference in water type. 
number of offispring per brood were inversely related as well, whereas, lifespan was more constant (ci' Table 3-3). These points suggest that these daphnids are flexible reproductively, In that they "trade oft" brond size and number per brood. This in turn suggests that reproduction is a major energetic expense to these animals, which supports the idea that Ceriodaphria reproduction (over a fixed number of broods) should be a sensitive endpoint for toxicity assessments. It also suggests the hypothesis that reproduction may eontrol longevity of these animals in predator-free situationts. The second, and perhaps more important finding from the two sets of ANOVA, was that the different water types did not alfect any of the reproductive parameters very strongly: the proportion of vartance in any parameter that could be explained by differences in water type never excecded $8.1 \%$ (Tables 3-4 and 3-5). This consideration, in conjunction with the tendency for the animals to trade off brood size and number per brood, indicate that water from MCK 1.92 was not toxic. it also strongly suggests that food-related aspects of lesting ambient waters with Ceriodaphinia may need to be addressed more carefully, both in eflluent and ambient testing situations.

\subsubsection{In Situ Snail 'Test}

Snail movement patterns differed significantly among the three sites $(G=22.95$, $p<0 .(0) 1)$. Fewer than $25 \%$ of the snails released at MCK 1.60$)$ moved upstream, whereas, $>75 \%$ moved upstream at MCK 1.92 and WCK 6.3 (Fig. 3-1). In $48 \mathrm{~h}$, the maximum downstrean movement of the snails at MCK 1.60), MCK 1.92, and WCK. 6.3 was $2.80,0.60$, and $1.88 \mathrm{~m}$, respectively. Median distances that snails moved upstream did not appear $(0)$ dilfer between MCK 1.92 and WCK $6.3(G=4.045,0.05>p>0.020)$, but did differ between MCK 1.60 and MCK $1.92(G=22.132, p<0.001)$, and between WCK 6.3 and MCK 1.60) $(G=13.718, p<0 .(0) 1)$. Because of multiple testing, a conservative Type I error rate $(0 .(120)$ was used. More than $50 \%$ of the marked snails were recovered at each of the MeCoy Branch sites; $27 \%$ of the snails that had been marked and released were recovered from WCK 6.3 .

\subsubsection{Scren-Day Snail Test}

The feeding rates of the snails in water from WCK 6.3 and McCoy Branch at MCK 1.92 were quile similar $(56.3 \pm 5.3$ and $54.3 \pm 6.4 \mathrm{mg}$ wet mass consumed per day, respectively; means ts standard error); snails in water from MCK 1.60), in contrast, had feeding rates that were about $25 \%$ lower than those tered in waler from the other two sites (i.c., 40.9 +5.3 mg wet mass per day). The leedi rates did not, however, difler statistically based on ANOVA $(p=0.215)$. Feeding $r$ s differed arnong dates (ANOVA, $p=(0.0(0) 1)$, and the rates increased unilormly toward. the end of the experiment. The lieeding rates showed no significant site $X$ dale interaction (ANOVA, $p=0.3222$ ).

\subsubsection{Chomical Analyses of Warer Quality}

Daily analyses of $\mathrm{pH}$, conductivity, alkalinity and hardness were conducted for six of the 7-d loxicity lesting periods (Table 3-6). Concentrations of nitrate, phosphate, and sulfate were measured in water lirom MoCoy Branch at MCK 1.92 during two of the 7-d test periods (Table 3-7). During April 5-11, 1900), the phosphate levels at the upstream 
3.11

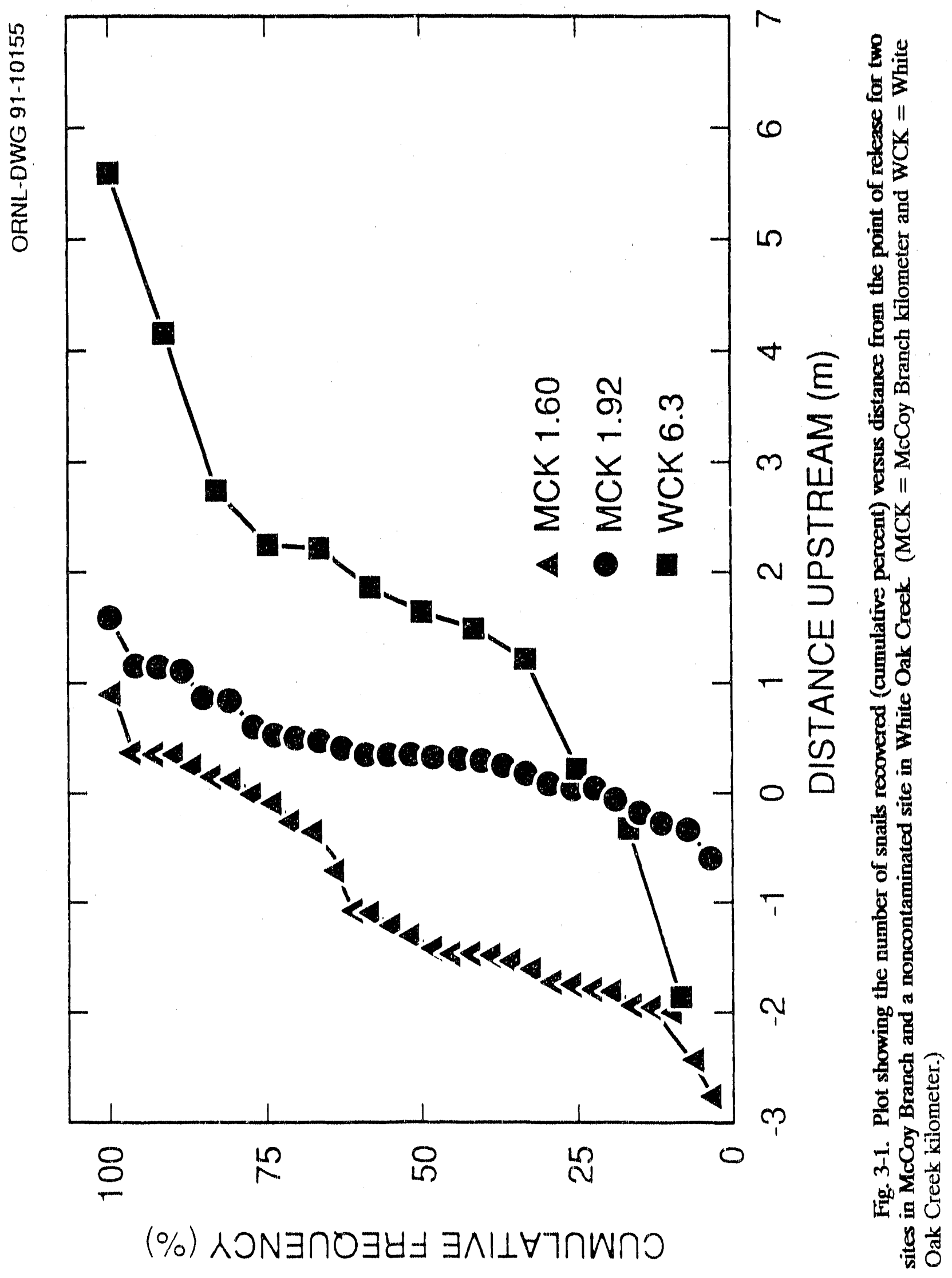




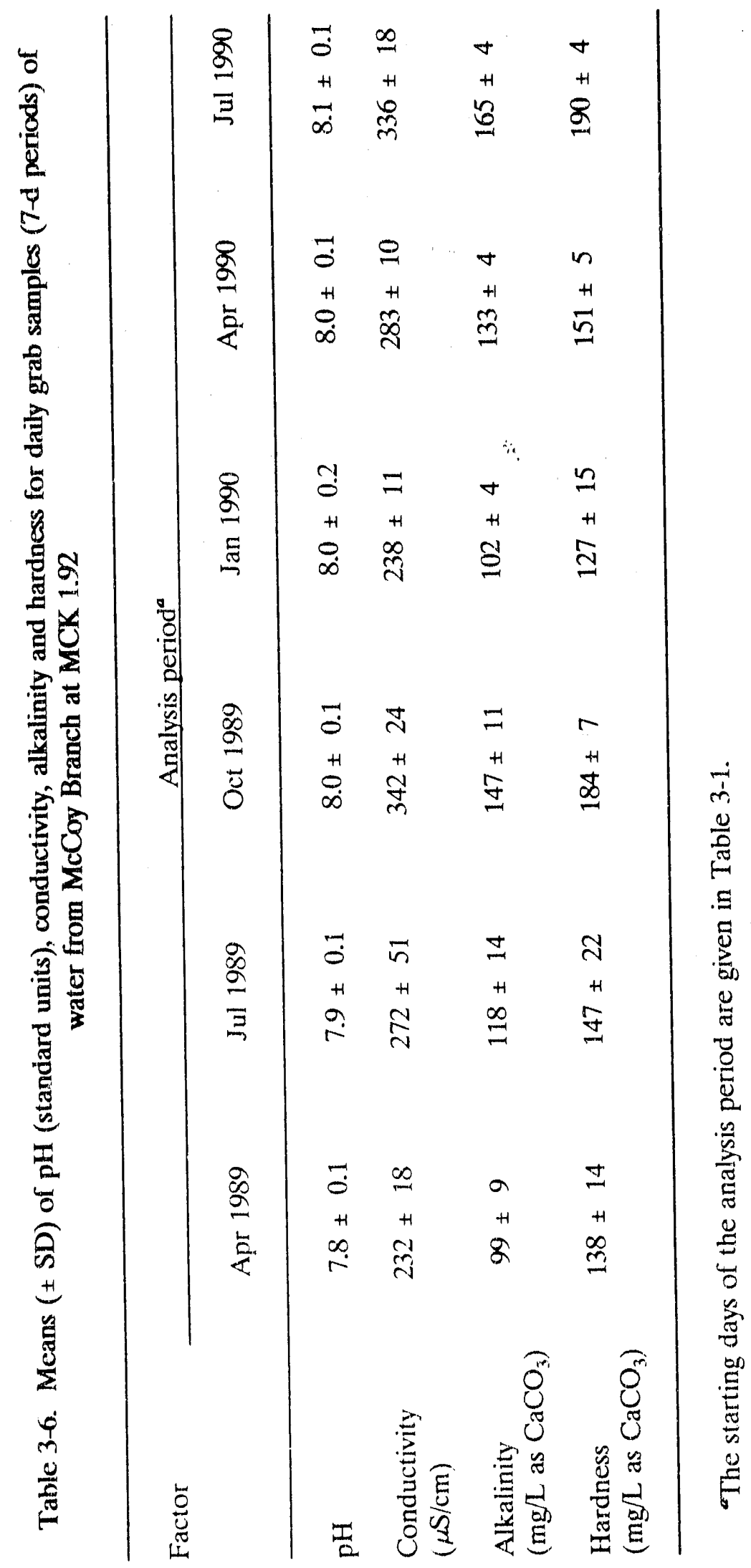




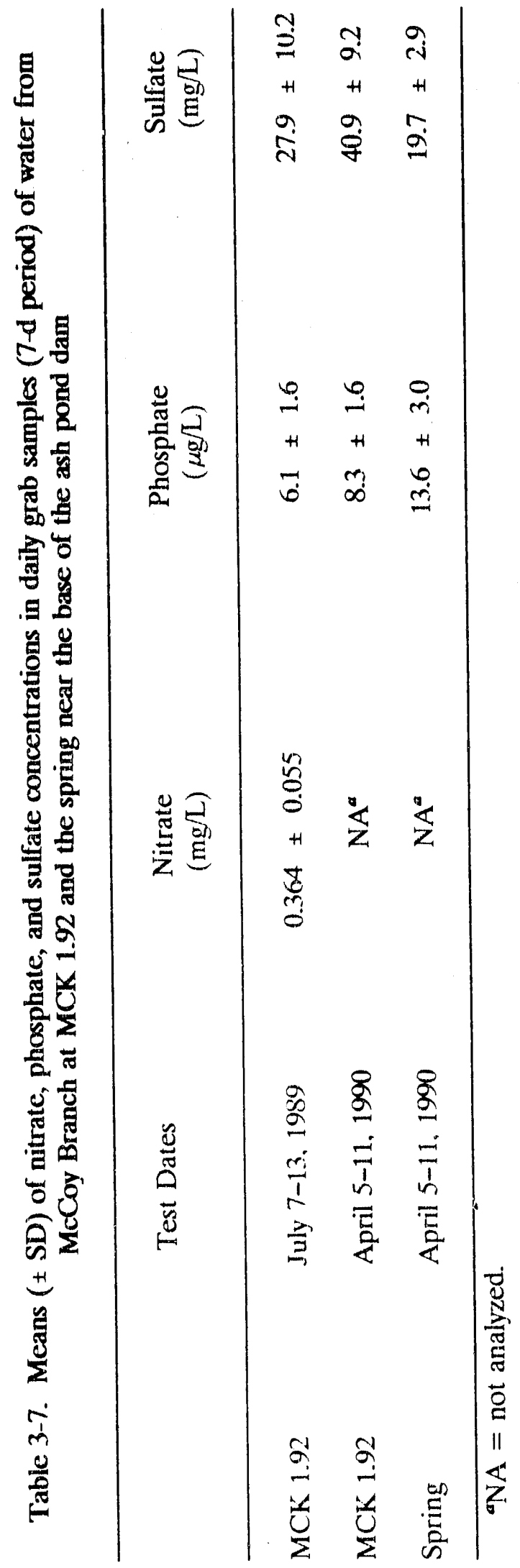


spring site were higher than those at MCK 1.92, whereas, the sulfate values were lower (Table 3-7).

Water samples during July 30-August 5, 1990, from McCoy Branch at MCK 1.60 were analyzed for $\mathrm{pH}$, conductivity, alkalinity and hardness. During April 5-11, 1990), samples from the spring at the base of the ash pond were also analyzed for these parameters. The results of these two sets of analyses are summarized in Table 3-8.

\subsection{DISCUSSION}

The results of the biological tests of water from McCoy Branch reported here did not show much evidence lor toxic conditions in this stream. In 7-d laboratory tests, survival and growth of fathead minnow larvac, and survival and fecundity of Ceriodaphnia was generally high, although a lew exceptions to this trend were evident. Similarly, full LCTs with Ceriodaphnia, which should be considerably more sensitive than 7-d tests, also failed to show much effect of McCoy Branch water. LCTs also showed Ceriodaphnia had significantly fewer broods and a slightly lower mean daily fecundity in McCoy Branch water than they did in the controls, but the number of neonates per brood tended to be greater than that in controls. Thus, the net effect of McCoy Branch water on Ceriodaphnia fecundity was small. Longevity of Ceriodaphnia in McCoy Branch water was also very similar to that for the controls ( $24.3 \mathrm{~d}$ for animals in McCoy Branch water versus 23.1 d for controls, Table 3-3).

In the in situ tests, snails apparently experienced more stress in McCoy Branch at MCK 1.60) than they did at either MCK 1.92 or at WCK 6.3. At MCK 1.60, the net movement of snails was downstream; whereas, the net movement of the snails at the other two sites was upstream. Studies of snails in noncontaminated streams have indicated that an upstream movement of snails is typical (Crutchfield 1966; Houp 1970; Burris et al. 1990). Conversely, when healthy snails were placed in contaminated streams, the net movement was downstream (Burris et al. 1990). Snails may actively move downstream as an escape hehavior or may be passively transported downstream by flow.

In 7-d laboratory tests, snails consumed less food when tested in water from MeCoy Branch at MCK 1.60) than they did in water from either MCK 1.92 or WCK 6.3, but this differenec was not stalistically significant.

During the summer, the water in McCoy Branch at MCK 1.60) is warmer than that at MCK 1.92 or WCK 6.3 (see Table A-8), primarily because MCK 1.60 receives epilimnetic llow from the quarry. Because Elimia are not very heat tolerant (Ross and Ultsch 1980), warmer temperature could aceount for the differences in suail behavior between MCK 1.60, and MCK 1.92 and WCK 6.3. However, heat stress is unlikely to account for differenees seen in the laboratory where temperature was controlled.

The mean ratio of alkalinity to hardness (A:H) for MCK 1.92 was ().811, and the mean conductivily was $284 \mu \mathrm{S} / \mathrm{cm}$ (Table 3-6). The A:H and conductivity values for MCK 1.92 are within the $95 \%$ confidence bounds for those reported for reference sites in upper WOC, First Creek, and Filth Creek (Stewart 1990). Similarly, the A:H for samples 
Table 3-8. Means ( \pm SD) of pH, conductivity, alkalinity, and hardness for daily grab samples (7-d periods) of water from McCoy Branch at MCK 1.60 (July 30-August 5, 1990) and the spring at the base of the ash pond dam (April 5-11, 1990)

\begin{tabular}{lcc}
\multicolumn{1}{c}{ Factor } & MCK 1.60) & Spring \\
\hline $\begin{array}{l}\text { pH } \\
\text { (standard units) }\end{array}$ & $8.5 \pm 0.1$ & $7.5 \pm 0.2$ \\
$\begin{array}{l}\text { Conductivity } \\
(\mu \mathrm{S} / \mathrm{cm})\end{array}$ & $233 \pm 4$ & $351 \pm 54$ \\
$\begin{array}{l}\text { Alkalinity } \\
(\mathrm{mg} / \mathrm{L})\end{array}$ & $83 \pm 2$ & $151 \pm 20$ \\
$\begin{array}{l}\text { Hardness } \\
(\mathrm{mg} / \mathrm{L})\end{array}$ & $125 \pm 6$ & $174 \pm 11$ \\
\hline
\end{tabular}


from MCK 1.60) was 0.664; whereas, A:H for the spring at the base of the ash pond dam was 0.868 (Table $3-8$ ). Thus, as for other streams, the overall trend was for a decline in A: $\mathrm{H}$ with distance downstream, but the rate and total extent of decline was not very great. Phosphate, which tends to be biologically quite reactive, was also present at relatively low concentrations in water from the spring at the base of the ash pond dam and from MCK 1.92 (Table 3-7). This element is often elevated by a factor of 10 to 100 in streams that receive industrial effluents. Thus, the results of the chemical analyses suggest that the stream is not highly perturbed. This conclusion is in good general agreement with the results of toxicity tests.

\subsection{FUTURE STUDIES}

Quarterly tests with Ceriodaphnia and fathead minnow larvac will be conducted at MCK 1.60 and MCK 1.92 to monitor possible changes in water quality that occur in McCoy Branch. Snail release studies will also be continued to determine if these grazers can persist and grow if transferred into McCoy Branch sites upstream from Rogers Quarry. 


\section{BIOACCUMULATION STUDIES}

\subsection{INTRODUCTION}

McCoy Branch received discharges of coal ash effluents from Y-12 (Sect. 2.2.1). Metals and hydrophobic organic chemicals in these discharges (Sect. 2.2) may accumulate in the biota of McCoy Branch, Rogers Quarry, or downstream in Melton Hill Reservoir to levels that may diminish the value of these resources. The primary objectives of contaminant monitoring in McCoy Branch biota were to (1) identify any substances that accumulate to levels exceeding those observed in biota from nearby, uncontaminated reference streams and (2) evaluate the extent and significance of contamination by those substances in McCoy Branch and downstream aquatic systems. Secondary objectives were to assist in locating sources of contaminants that accumulate to unacceptable levels, and to evaluate the relative importance of present vs. past discharges in determining contaminant levels of biota.

Initial surveys of McCoy Branch indicated that only a limited area of the stream contained enough fish to sample for bioaccumulation potential in aquatic biota, and this area was open to immigration from Melton Hill Reservoir. Because Rogers Quarry contained suitable lish populations that are virtually isolated from immigration from Melton Hill Reservoir, the collections were made from this site to evaluate bioaccumulation concerns associated with the coal ash discharge. McCoy Branch embayment of Melton Hill Reservoir was sampled to provide a basis for evaluating if fish from the quarry contained elevated concentrations of certain contaminants, and also to ensure that no public health concerns were associated with the ultimate discharge of McCoy Branch water to that portion of the reservoir.

\subsection{METHODS}

Largemouth bass (Micropterus salmoides) were collected from Rogers Quarry and the adjacent McCoy Branch embayment of Melton Hill Reservoir in July 1990 by angling and electrofishing. The lish were placed on ice and returned to the laboratory where they were weighed and measured. The bass were filleted and skinned, and samples of the anterior dorsal portion of the fillet was removed for analysis for mercury, arsenic, selenium, other trace metals, chlorinated organic pesticides, and PCBs at the ORNL Analytical Chemistry Division (ACD). Mercury was analyzed by cold vapor atomic absorption spectrophotometry after digestion in a mixture of perchloric and nitric acids (EPA Methods 3050 and 245.5 for preparation and analysis, respectively, EPA 1986). Following digestion in nitric acid, arsenic, beryllium, and uranium were analyzed by inductively coupled plasma mass spectrometry; and antimony, cadmium, chromium, copper, lead, nickel, selenium, silver, thallium, and zinc were analyzed by inductively coupled plasma optical emission spectrometry (EPA Methods 3050 and 6010, EPA 1986). A 10-g sample of the fish fillet was extracted by ultrasonic disruption in methylene chloride, cleaned up by column chromatography, and analyzed for PCBs and chlorinated pesticides by gas chromatography with electron capture detection (EPA method 8080, EPA 1986). 
Quality assurance (QA) was maintained using a combination of (1) blind duplicate analyses; (2) split sample analyses between the EPA Environmental Services Laboratory, Athens, Georgia, and the ACD Laboratory; and (3) the analyses of biological reference standards and uncontaminated lish. Recoveries of PCBs, selected metals, and organics were verified by spiking uncontaminated fish with known amounts and analyzing them.

Statistical cvaluation of the data was conducted using linear regression, analysis of variance (ANOVA), Levenes test for homogeneity of variances, and analysis of covariance (SAS 1985a,b). All comparisons used alpha $=0.05$.

\subsection{RESULTS AND DISCUSSION}

Concentrations of elements in individual largemouth bass from Rogers Quarry and McCoy Branch embayment are listed in Table 4-1. Mean concentrations of most metals (antimony, beryllium, cadmium, chromium, copper, lead, mercury, nickel, silver, uranium, and zinc) in bass (rom Rogers Quarry and McCoy Branch embayment were similar to concentrations in reference stream sunfish (Table 4-2). The concentrations in McCoy Branch bass were also similar to those found in various species from other sites both locally and nationwide (TVA 1985; Dycus and Hickman 1986; Dycus 1989; Lowe et al. 1985). The mean concentrations of elements were all below concentrations used by EPA (EPA, personal communication) and others (Hoffman et al. 1984; C. C. Travis, Health and Safety Division, ORNL, personal communication) to screen for levels of contamination that pose no threat for human consumption (Table 4-2). Only arsenic was present at concentrations above screening criteria; however, the screening concentration for arsenic is below the detection limit for arsenic in fish, and also well below concentrations typical of most biological materials (Bowen 1979).

Thallium was detected in seven of eight bass from Rogers Quarry, but not in lish from McCoy Branch embayment. However, the concentrations were at or near the analytical detection limit and, therefore, must be regarded cautiously. Although data suggest that thallium may be elevated above background levels in Rogers Quarry, evaluation with more sensitive analytical methods is needed for verification.

Concentrations of two elements, selenium and arsenic, in bass from Rogers Quarry were significanlly (ANOVA) elevated above concentrations in bass from McCoy Branch embayment (Table 4-2). The mean concentration of arsenic in bass from the quarry was $0.29 \pm 0 .(12 \mu \mathrm{g} / \mathrm{g}$, about twice the amount $(0.14 \pm 0.02 \mu \mathrm{g} / \mathrm{g}$ ) found in fish from the reservoir. Selenium was also substantially higher in the bass from Rogers Quarry, averaging $3.00 \pm(0.11 \mu \mathrm{g} / \mathrm{g}$ versus $1 .(4) \pm 0.29 \mu \mathrm{g} / \mathrm{g}$. Thallium also appeared to be elevated in hass from the quarry; however, concentrations were too near the detection limit to regard this result as conclusive. Mercury concentrations in fish from the quarry were among the lowest observed in largemouth bass in the United States and substantially lower than concentrations in fish from Melton Hill Reservoir.

The mean concentrations of arsenic in the bass from McCoy Branch embayment may be elevated above ivpical background levels. Arsenic has never been found to exeed the detection limit $(0.05 \mu \mathrm{g} / \mathrm{g})$ in sunlish analyzed for biological monitoring programs at 


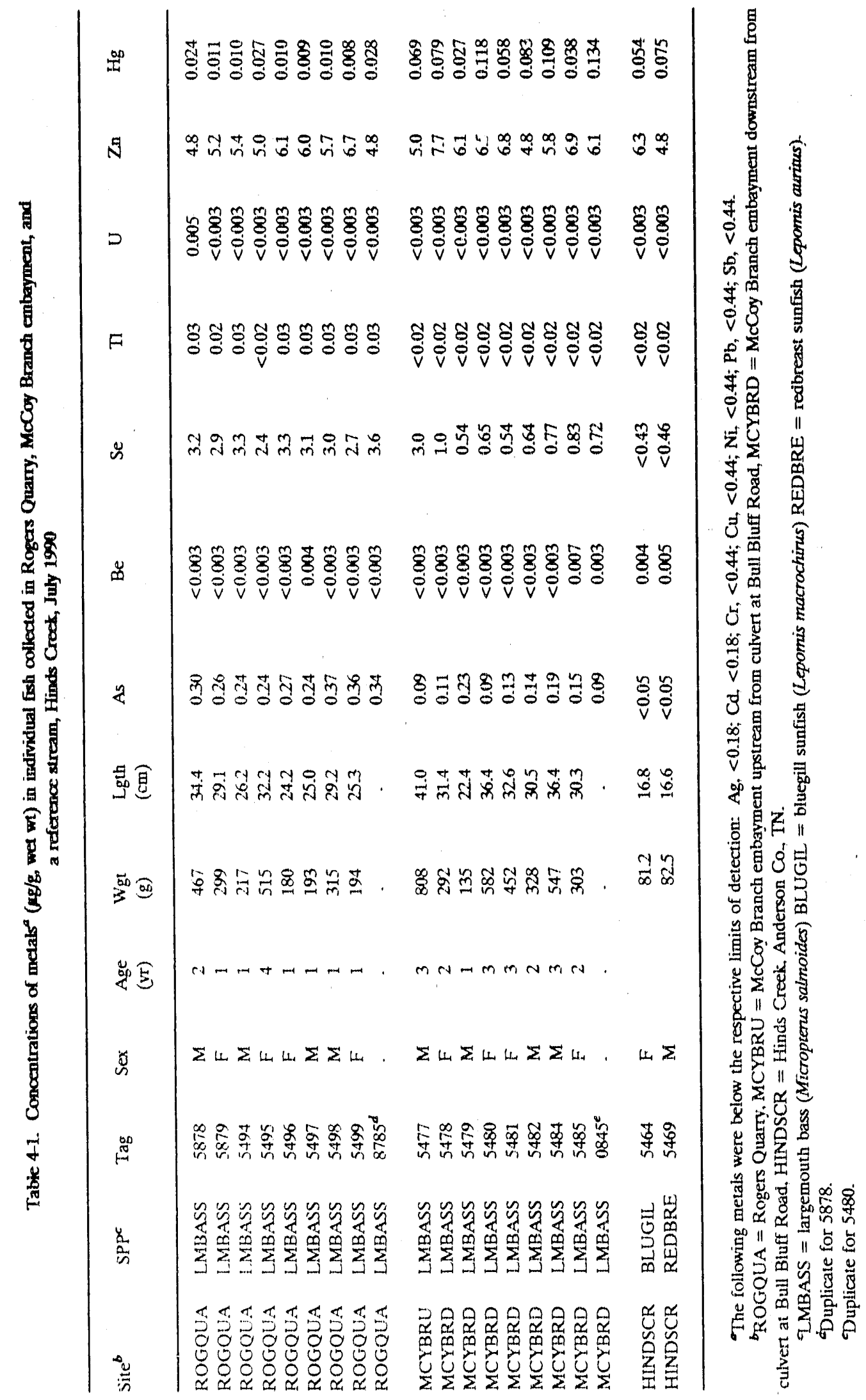




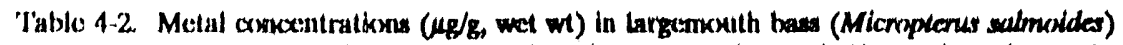
from Rergers Quarry and McCey Hranch emberyment and sunfish (Lepomis ouritus and 1. macrochinus) from Hinds (Cnsect, a reforcince striant"

\begin{tabular}{|c|c|c|c|c|c|c|c|}
\hline Melal & $\begin{array}{l}\text { Rogurs } \\
\text { Quarty }\end{array}$ & $\begin{array}{l}\text { Mccoy [3ranch } \\
\text { Embuyment }\end{array}$ & $\begin{array}{l}\text { Hilnds } \\
\text { Crecke }\end{array}$ & 'IVAd & USFWS & poiv' & $\mathrm{BH} \mathrm{A}^{\mathrm{B}}$ \\
\hline Antimony & $<0.44$ & $<0.44$ & $<0,44$ & $<2$ & $\ldots$ & 5.2 & 4.3 .1 \\
\hline Arsenic & $\begin{array}{c}0.29 \\
(0.02)\end{array}$ & $\begin{array}{c}0.14 \\
(0.02)\end{array}$ & $<0.05$ & 0.16 & 0.16 & $0.0 \times 007$ & 0.00612 \\
\hline Beryllium & $<0,(0) .3$ & $<0,000,3$ & $\begin{array}{c}0.005 \\
(0.00) 5)\end{array}$ & $<0,02$ & $\cdots$ & 0.004 & $0.0 \times 025$ \\
\hline Cadmium & $<0.18$ & $<0,18$ & $<0.18$ & 0.02 & 0.04 & 1.0 & 10.8 \\
\hline Chromium & $<0.44$ & $<0,44$ & $<0,44$ & 0,82 & $\ldots$ & 1.8 & 10800 \\
\hline Copper & $<0.44$ & $<0,44$ & $<0.44$ & 1.2 & 0.86 & 36 & $\cdots$ \\
\hline lead & $<0.44$ & $<0.44$ & $<0,44$ & 0.06 & 0.19 & 1.8 & $\ldots$ \\
\hline Mercury & $\begin{array}{l}0.014 \\
(10.002)\end{array}$ & $\begin{array}{c}0.073 \\
(0.011)\end{array}$ & $\begin{array}{c}0.065 \\
(0.011)\end{array}$ & 0.30 & 0.11 & 0.42 & 1.0 \\
\hline Nickel & $<0.44$ & $<0,44$ & $<0.44$ & $<1,0$ & $\ldots$ & 5.2 & 21.5 \\
\hline Siclenium & $\begin{array}{c}3,00 \\
(0.11)\end{array}$ & $\begin{array}{c}1 .(0) \\
(0,29)\end{array}$ & $<0.45$ & 0.28 & 0.46 & 12 & 5.4 \\
\hline Silver & $<0.18$ & $<0.18$ & $<0.18$ & $<0.2$ & $\cdots$ & 0.29 & 2.48 \\
\hline Thallium & $\begin{array}{l}0.03 .3 \\
\left(0.000^{\prime}\right)\end{array}$ & $<0.02$ & $<0.02$ & $<1$ & $\cdots$ & 0.66 & 5.71 \\
\hline Iranium & $<0,(0)(1)$, & $<0.0003$ & $<0 .(80) 3$ & $\ldots$ & $\ldots$ & 1.6 & $\cdots$ \\
\hline Yinc & $\begin{array}{c}5.6 \\
(0.22)\end{array}$ & $\begin{array}{c}6.2 \\
(0.35)\end{array}$ & $\begin{array}{c}5.6 \\
(0.80)\end{array}$ & 9.2 & 25.6 & 180 & $\ldots$ \\
\hline
\end{tabular}

a lahular values lor these siles are mean and SF: (in parentheses). Additional dalla are roference concentrations from olluer sludies ('Iennessec Valley Authority, United Stales lïsh and Wildife Servlce) and risk based criteria (Preliminary (indiance Value, linvirommental Protection Agency).

${ }^{b} \mathrm{~N}=8$.

${ }^{c} \mathrm{~N}=2$.

${ }^{d}$ (ompensite latgemomth hats, $N=10$ (Dycus 1989; Dycus and llickman 1986).

'1 onve et inl. 1985.

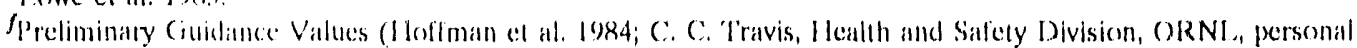
communication).

8t invironmental l'rotection Agency, personal communication. 
ORNL, Y-12, and K-25 (Southworth 1991: G. R. Southworth, Environmental Sciences Division, ORNL, personal communication); however, all the largemouth bass collected from MeCoy Branch embayment contuined measurable arsenic concentrations (Table 4-1). The mean concentration of arsonic found in MoCoy Branch ombayment bass was similar to the nationwide mean concentration found in the National Contaminant Biomonitoring Program (Lowe et al. 1985) sampling various species (Table 4-2). The McCoy Branch mean was also similar to the mean concentration found in composite largemouth bass samples from seven sites in the TVA region (Table 4-2) in sirecning studies conducted by TVA (Dycus and Hickman 1986; Dycus 1989). The criterion used to indicate a need for follow-up sampling in the T'VA screening studies is $0.5 \mu \mathrm{g} / \mathrm{g}$ for arsenic.

The mean selenium concentration in bass from McCoy Branch embayment excecded the mean concentrations observed in both the National Contaminant Biomonitoring Program (Lowe el al. 1985) and the TVA investigations (Dycus and Hickman 1986; Dycus 1989) (Table 4-2). Typical concentrations observed in suntish in the ORR Biological Monitoring Programs were 0.4 to $0.6 \mu \mathrm{g} / \mathrm{g}$ (Southworth 1991; G. R. Southworth, Environmental Sciences Division, ORNL, personal communication). Thus, sclenium concentrations in bass from McCoy Branch embayment are clearly elevated. Although they are well below concentrations used to sereen for human health concerns in lish consumers (Table 4-2), the mean concentration is equal to the criteria used by TVA to initiate follow up studies (Dycus 1989).

The presence of elevated concentrations of selenium and arsenic in fish from Rogers Quarry was not surprising, because surfice water in MoCoy Branch contained high concentrations of these substances for several years prior to the reduction of coal burned at the Y-12 Steam Plant in 1988 and subsequent elimination of tly ash discharges 0 Rogers Quarry in 1990 (Fig. 2.5). Average concentrations of these olements measured by NPDES monitoring in McCoy Branch were much lower, averaging $<46 \mu \mathrm{g} / \mathrm{L}$ arsenic and $4.3 \mu \mathrm{g} / \mathrm{L}$ selenium in the year preceding the fish sampling (Sect. 2.2.2, Figs. 2-4 and 2-5).

Several recent studies have suggested that adding selenium to waters in which mercury bioaceumulation in lish is excessive could ameliorate the problem (Rudd et al. 1980, Turner and Rudd 1983, Turner and Swick 1983, Bjornberg et al. 1988). However, a recent study by Curvin and Furness (1988) found that simultaneous exposure of minnows to dissolved mercury and selenium resulted in more rapid accumulation of mercury than was observed in the absence of selenium. They also note the positive correlation between lissue concentrations of mercury and sclenium in large oceanic fish.

The mean mercury concentration in largemouth bass from Rogers Quarry, ().014 $\pm 0.002 \mathrm{\mu g} / \mathrm{g}$, was much lower than that in fish from the adjacent reservoir, $0 .(07.3 \pm 0.011 \mu \mathrm{g} / \mathrm{g}$ ('Table 4-2). A positive correlation between lish size and mercury concentration is commonly found in lish from the same site, which complicales comparisons of mercury concentrations among fish from different sites, because the mean weight of the fish sampled from Rogers Quarry was smaller than that of fish from MeCoy Branch embayment. In this casce, lish liom Rogers Quarry exhibited a statistically significant relationship between fish weight and mercury concentration: 


$$
|\mathrm{Hg}|=5.4() \times 10^{-5}(w g t)-(),(k) 2
$$

A similar rolatkonshlp was found in the MoCoy Branch ombayment lish, but the slope of' the relationship) did not differ significanlly from zero:

$$
|\mathrm{Hg}|=8.11 \times 10^{-5}(\mathrm{wgt})+0.038
$$

Because slopes of the two relationships did not differ signifleantly from each other, mercury concentrations could be compared in a straightforward fashion using analysis of covarlance. 'The results of such a comparison indicated that the difference in mereury eoncentrations in lish between the two sites was indeed statistically significant. If Eq. I is used to estimate the mercury conecntration in Rogers Quarry lish of mean weight (4.30 g) equal to the mean weight in the Melton Hill Reservolr collection, the difference remalns very large, 0.02 .5 versus $(0.073 \mathrm{\mu g} / \mathrm{g}$.

Mercury concentrations in largemouth bass from Rogers Quarry are among the lowest reported for this species. Concentrations mensured by TVA in bass from 11 other

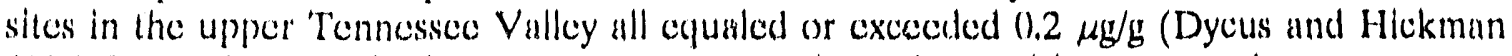
1986; Dycus 1989). The lowest mean concestrations observed in an extensive survey (96 sites) of lakes and streams in Florida were 0.04 and $0.07 \mu \mathrm{g} / \mathrm{g}$ in two highly cutrophle lakes (Hand and Friedman 19(2)). Concentrations at other locations typically exceeded $0.2 \mu \mathrm{g} / \mathrm{g}$ in that study, with most excecding $0.5 \mu \mathrm{g} / \mathrm{g}$. Only one of 39 composite largemouth bass samples analyzed in the National Contaminant Biomonitoring Program, 1978-1981, contained $0.02 \mu \mathrm{g} / \mathrm{g}$ or less of mercury (Lowe et al. 1985).

Although mercury concentrations in fish from Rogers Quarry were fur lower than those typically found in largemouth bass, similar concentrations have been observed previously in bass from Melton Hill Reservoir. Largemouth bass collected in 1976 averaged $0.02 \mu \mathrm{g} / \mathrm{h}$. (Elwood 1984). Monitoring conducted from 1979 10 1983 by ORNI. lound morcury concentrations in single composite samples of largemouth bass to range from $0.01600 .10 \mathrm{\mu g} / \mathrm{g}$, averaging 0.05 $\mathrm{\mu g} / \mathrm{g}$ (Martin Marjetla Energy Systems 1985). Analyses of individual lish were conducted in 1984 and 1985, and reported moan

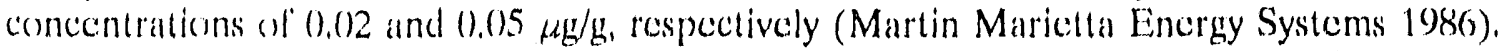
Sampling by 'TVA in 1984 reported a mean concentration ol' $0.12 \mu \mathrm{g} / \mathrm{g}$ for 10 fish ('TVA 1985). Basss collected in lall 1989 from two sites on Melton Hill Reservoir averaged 0.10 $\mu \mathrm{g} / \mathrm{g}(\mathrm{n}=8)(\mathrm{S} . \mathrm{M}$. Adams, Environmental Sciences Division, ORNL, personal communication). Thus, it appears that mercury concentrations measured in bass from Melon Hill Reservoir in the past have been quite low and not unlike those observed in lish from Rogers Quarry. However, it also appoars that measurements of mercury in Melen Hill Rescrvoir bass made since 1984 indicate that concentrations much higher than those observed in lish from Rogers Quarry are now typical of this lake.

The lace that very low eonecentrations of mercury have been observed in Meleon Hill Reservoir fish in the past suggest that the low concentrations found in Rogers Quarry fish maly result not from the presence of elevaled coneentrations of selenium in water and biota, but rather lrom unusually low concentrations of mercury in the water or some other licter limiting the proluction of methylmercury in this system. While it is impessible to disprove this hypothesis with the limited monitoring data presented here, NPDES 
monitoring of alyucous moreury concentrations in MeCoy Branch suggest hant this stroum has oceasionally contalned clovaled mercury concentrations in the past (Rogers et al. 1988, 1989). Thus, it is unllkely that the low concentrations of moreury in Rogers Quarry flish are a result ol' unusually low concentrations of mercury in the quarry wator, and it is likely that the cuarry actually contuins higher eoncentrations of mercury than uncontaminated raturul waters. It appears that the presence of $2-4 \mathrm{mg} / \mathrm{L}$ selenlum in wator In Rogers Quarry reduced the matural accumulation of mercury by a substantial amount, in Hgrecment with speculation of 'Turner and Rudd (1983).

The measurements of selenium and arsenic concentrations in lish and whter from Roger Qutrry enn also bo used lo calculate bioconcentration findors for these two elements. Although a simple ratio cannol adequately describe or predict bionceumulation of Inorgennle substances such as these because they: (1) may be lo some extent homesstatically regulated in lish, (2) may not exhibit a linear relationship between aguenus phase and biotic concentrations, und (3) may be accumulated significantly via food as well as direct acpueous uplake; nevertheless, such rutios can be useful in extrapolating to similar circumstances and perhaps in providing additional indleses for evaluating the potential of contuminants to bionceumulate. Bioconcentration factors were calculated for these (wo eompounds by dividing the mean concentrations in lish in the quarry by the mean aqueous phase concentration in the quarry measured over the preceding year. Results of this calculation yiekded bicooncentration fiactors for selenium and arsenic of (9) (1) and 6.3, respectively. For comparison, bicooncentration factors used in formulating EPA waler guality eriteria for these two clements were 6 and 44 for selenium and arsenic, respectively. The large discrepancy for selenium may be due to the face that ingestion of selenium-contuminated forel is an important pulleway in the accumulation of this element in lish (Hodson lg()), and bioconcentration factors us used in EPA water quality criteria are based stricily on direct uplake from ayueous exposure.

Concentrations of pesticides and PCBs in individual bass lirom Rogers Quarry are listed in Tible 4.3. In all cases, the concentrations were far below the estimated detedion limits (Table 4.3), bul extremely low concentrations of l'our pesticides and pesticide metabolites (heptachlor, DDT, DDE, and chlordane) were, nevertheless, estimated in some individual lish. These estimated concentrations were well below EPA walce quality criteria scereening lovels (EPA 1O()) listed in l'able 4-3, which were calculated using the EPA Integralled Risk Information System (IRIS 1989). Such extremsly low estimated concentrations of organic contiminants camnot be used to reliatly inler that these compounds are in liace present in the lisht.

'Two ol' eight lish colleceded in Rogers (2uarry for contaminant analysis were deformed. Observed abnormatities involved bony structures of the tish including skull, gill opercula, fins, and seales. Each lish had severe erosion or incomplete development of the skull, giving it a misshapen, concave: heade. 'The bony portions of most fins were missing or ereded, and pelvie lins were missing. The beny portion of the ouler gill covers was malformed or incomplece in both lish. Lalleral line scales were missing in one fish; in the

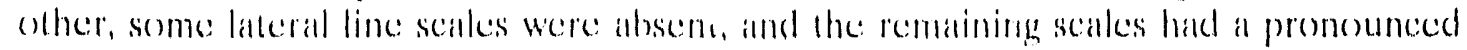
ridge. Both deformed lish were older than the remaining six fish collected in Rogers Quarry, with ane estimated from scale annuli an 2 and 4 years, versus 1 year for the normal appearing fish ('lable 42). Adelitional lish were capplured and rekeased in Rogers Quarry 


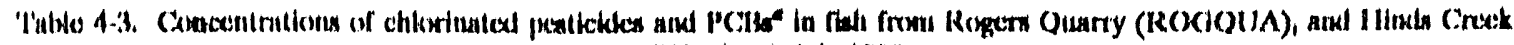
(IIINISSC:IR) Juty 1990

\begin{tabular}{|c|c|c|c|c|c|c|c|c|c|}
\hline \multirow[t]{2}{*}{ Sllu } & \multirow[t]{2}{*}{$s \mu p 1^{6}$} & \multirow[t]{2}{*}{ I'ng } & \multirow[t]{2}{*}{ Scx } & \multirow{2}{*}{$\begin{array}{l}W_{1} \\
(g)\end{array}$} & \multirow{2}{*}{$\begin{array}{l}\text { l.glh } \\
\text { (ciii) }\end{array}$} & Heneluchlor & DID' & DIDI? & Cylordence" \\
\hline & & & & & & \multicolumn{4}{|c|}{$(\| \mathrm{d} / \mathrm{g}$ wot $w 1)$} \\
\hline 12,0$)(\mathrm{i})(1 \mathrm{~A}$ & I.MHAS.S & 5878 & $M$ & 4617 & 34,4 & $(0,(K)) 2$ & $0,(x \times) 4$ & $<0,018$ & $0,(x)() !$ \\
\hline kor)riot)A & I.MHASS & $58 \% 9$ & $i$ & $2(x)$ & 20,1 & $0 .(x) / 4$ & $0,(x) \mid 0,0$ & $0,(0)(0) 7$ & $0,(k) .3$ \\
\hline KOCCOCUA & L.MHASS & $\$ 494$ & $M$ & 217 & 26,2 & $0,0)(x) .3$ & $<0,02,2$ & $0,0 \times(), 5$ & $0 .(6) \times 12$ \\
\hline KOC) & LMHASS & 94,195 & $\because$ & .515 & 32.2 & $<0,(0) 2$ & $<0,02 d$ & $0 .(K K) 2$ & $<0,012$ \\
\hline Rociogus & L.M|BASS & 5400 & $i$ & 180 & 24,2 & $<(0,0) 12$ & $<0,(024$ & $0 .(x)(x) 2$ & $<0.012$ \\
\hline kociolis & 1.MHASSS & 5.107 & $M$ & 193 & 25.0 & $<0,012$ & $<0,0,24$ & $0,0(x) 4$ & $<0,012$ \\
\hline$k() \cos (\mathrm{J} \Lambda$ & 1.MHASS & $\$ 408$ & $M$ & 315 & 29.2 & $<(0,0) 2$ & $<0.024$ & $0.0(K) Y 9$ & $0,0(0) 4$ \\
\hline$R()(1)|1|$ & LMBASS & $5,(1) 0$ & li & 104 & 24.3 & $<0,012$ & $<0,024$ & $<0,(124$ & $<0,012$ \\
\hline $\operatorname{loc}()(2) \operatorname{la}$ & 1.MHASS & $878 . s^{d}$ & . & 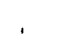 & , & $<0.012$ & $0,(K) \perp 6$ & $<0,024$ & $<0.012$ \\
\hline IIINISSC'R & 131.1ICHI. & 546.9 & li & 82.7 & 17.0 & $<0.02 .5$ & $<0.049$ & $<0,040$ & $<0.02 .5$ \\
\hline \multicolumn{6}{|c|}{ 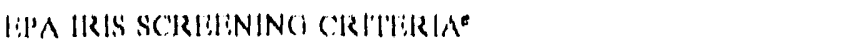 } & $0 .(x) 24$ & $0,0,32$ & 0.032 & 0.008 \\
\hline
\end{tabular}

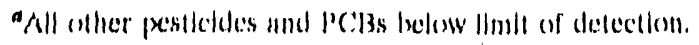

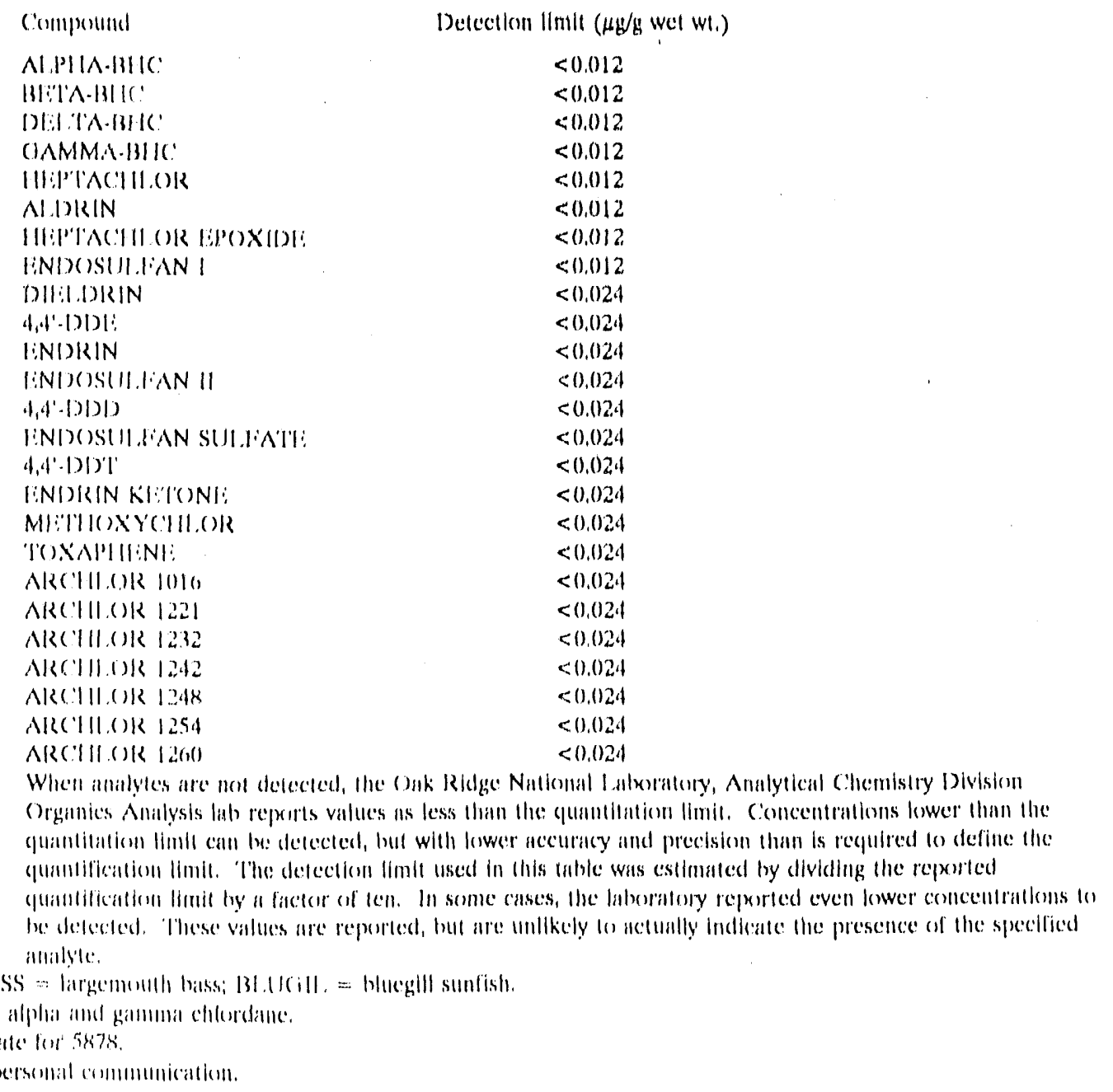


becaluse the collection effort was altempling to collect individuals representing a brotad range of sizes and ages. All lish released (approximately six) were similar in size and uppearance to the six undeformed lish in the collection. No abnormal bass were collected or observed in McCoy Branch embayment of Melton Hill Rescrvoir.

The concentrations of selenium in water from Rogers Quarry for the 12 months preceding the fish sampling were somewhat lower than concentrations $(5-1() \mu \mathrm{g} / \mathrm{L}$ ) observed in a selenium-contaminated lake (Belews Lake) where fish exhibitod severe adverse impacts (Hodson 199()). Sclenium concentrations in fish from Belews Lake (10-50 $\mu \mathrm{g} / \mathrm{g}$ ) were also higher than in Rogers Quarry (Hodson 1990). However, agueous selenium concentrations in Rogers Quarry in the years preceding 1989 were substantially

higher than those reported for Bolews Lake (Fig. 2-5). The deformed bass collected in Rogers Quarry would have been exposed to these higher solenium (and arsenic) concentrations if they were lifetime residents of the quarry. The undeformed lish collected in 1990) were all from the age class spawned in spring 1989 and, thus, would never have been exposed to the very high contaminant concentrations that oecurred previously.

Physiological changes characteristic of scelenium poisoning were reported in lish from Belews Lake (Hodson 1990); Sorensen et al. 1984) and another lly-ash-contaminated system, Martin lake (Sorensen and Batuer 1983). At Belews Lake, selenium exposure calused reproductive failure and a severe decline in fish populations within the alfected area (Hodson 199)); hewever, bony tissue abnormalities were not efted in elther system. It appears likely that the abnormalitics observed in Rogers Quarry bass are related to some dissolved constituent(s) in the coal ash discharge that has declined in concentration substantially sinee fly ash discharge (o) the quarry ceased. It does not appear likely that selenium was the caluse of the abnormalities. To date, we have not found evidenee in the literature that arsenic or thallium may be contributers to these eflects.

\subsection{CONCLUSIONS}

Concentrations of selenium, arsenic, and possibly thallium are elevated in largemouth bass Irom Rogers Quarry relative 10 bass from MoCoy Branch embayment and sunfïsh from Hinds Creck. Levels of sclenium and possibly arsenic appeared to be elevated above background in bass from McCoy Branch embayment of Meleon Hill Reservoir. Only arsenic exceds conservalively based sereconing critorial however virtually all biological materials exceed this criterion for ansenic. Cessiation of inputs of fly ash to the system, coupled with the rapid biokngical lurmever of selenium and arsenic, should result in continuing decreases in concentrations of these elements in lish. The very low concentrations of mercury in lish lirom Rogers Quarry are consistent with findings of other research on interaction between selenium and the bicaccumblation of mercury, and suggest rescarch areas for possible remediation of local mercury-contaminated systems.

Bioaccumbation of organte contaminants wals not indicalced in the MoCoy Branch discharge. 


\subsection{FUTURE STUDIES}

Largemouth bass in Rogers Quarry and McCoy Branch embayment will be sampled and analyzed for metals again in 1991 to ascertain whether or not coricentrations of arsenic, selenium, and thallium decrease as expected. Largemouth bass will also be collected from a reference site more similar to Rogers Quarry, such as Lambert Cuarry. At the same time, a more extensive survey of the incidence of bony structure deformities will be carried out. Further review of the scientific literature for possible agents that cause abnormalities similar to those found in Rogers Quarry bass will be conducted. 


\section{FISH COMMUNITY ASSESSMENT}

\subsection{INTRODUCTION}

Fish population and community studies can be used to assess the ecological effects of water quality and habitat. These studies offer several advantages over other indicators of environmental quality (Karr et al. 1986; Karr 1987) and are relevant to any evaluation of the biotic integrity of streams such as McCoy Branch. Fish communities, for example, comprise several trophic levels with species that are at, or near, the end of food chains. Consequently, they integrate the direct effects of water quality and habitat changes on primary producers (periphyton) and consumers (benthic invertebrates), which are used for food. Because of these trophic interrelationships, the well-being of fish populations has often been used as an index of water quality (Weber 1973; Greeson et al. 1977; Karr et al. 1986). Moreover, statements about the condition of the fish community are better understood by the general public (Karr 1981).

The initial objectives of the fish community monitoring task were to (1) characterize spatial and temporal patterns in distribution and abundance of fishes in McCoy Branch. and (2) document any effects on fish community structure and function resulting from implementation of the remedial actions as discussed in the McCoy Branch RFI (Murphy and Loar 1988).

\subsection{METHODS}

The fish community in McCoy Branch was evaluated at one area upstream and one area downstream from Rogers Quarry (Fig. 2-2); hoth areas are potentially impacted by coal ash effluent (Sect. 2.2.3). The upstream area was sampled qualitatively over a long stream reach to determine absence or presence of fish. The downstream area was sampled quantitatively at McCoy Branch kilometer (MCK) 1.56 to measure population parameters. Similar quantitative samples were made at two nearby reference sites |Grassy Creek kilometer (GCK) 2.4 and White Oak Creck kilometer (WCK) 6.8j for comparison of population parameters (Fig. 2-1). No attempt was made to survey the quarry itself.

Both qualitative and quantitative sampling was conducted using a Smith-Root Model 15A backpack electrofisher. The unit has a self-contained, gasoline-powered generator capable of delivering up to $1200 \mathrm{~V}$ of pulsed, direet current. The pulse frequency and the output voltage can be varied, but generally a pulse frequency of 9()$-120 \mathrm{~Hz}$ and a voltage of less than $400 \mathrm{~V}$ wass used.

For qualitative sampling, one electrofisher and one netler made a single clectrofishing survey upstream through the stream. A majority of the stream and all major tributaries were sampled. T'wo surveys (11 May 1989 and 15 June 1991) covered the stream from the Rogers Quarry inlet (MCK 1.92) to a large earthen dam (MCK 2.65) upstream. Another, survey (14 December 1987) was made of the stream sections above the earthen dam. Stunned fish were to be kept and identified to species. 
For quantitative sampling, a $0.64-\mathrm{cm}$ mesh seine was placed across the upper and lower boundaries of the fish sampling site to restrict fish movement. The sampling site (MCK 1.56) varied between $46-50 \mathrm{~m}$ in length (Table 5-1) for the three sampling surveys. A quantitative sample involved one electrofisher and one or two netters. This sampling team electrofished upstream through the site, collecting stunned fish for three separate passes. The fish were separated by pass in buckets prior to processing. Depending upon the turbidity of the water, the consecutive passes could not always be made immediately. Rather, fish were processed after each pass to allow sufficient time for the water to clear before another pass was started.

Following the electrofishing, fish were anesthetized with MS-222 (tricaine methanesulfonate) and processed. To process the fish, they were identified, measured to the nearest $0.1 \mathrm{~cm}$ (total length), and weighed to the nearest $0.1 \mathrm{~g}$ (for fish $<100 \mathrm{~g}$ ) or gram (for fish $>100 \mathrm{~g}$ ) using Pesola spring scales. At sites with high fish densities, individuals were recorded by $1 \mathrm{~cm}$ size classes and species. After 25 individuals of a species-size class were measured and weighed, additional members of that size class were only measured. Length-weight regressions were later used to estimate weight for unweighed fish (Railsback et al. 1989). Other data recorded (if possible to determine), included sex, reproductive state, disposition (i.e., dead or kept for laboratory identification and inclusion in a reference collection), and the presence of any abnormalities (e.g., external parasites or skeletal deformities). After processing fish from all passes, the fish were allowed to fully recover from the anesthetic and were returned to the stream within the sampling site. Any additional mortality occurring as a result of processing was noted at that time.

In addition to data on individual fish, data on selected physical and chemical parameters and the sampling effort were recorded. An Horiba Model U-7 Water Quality Checker was used to measure pH, temperature, dissolved oxygen, and conductivity. An HF Instruments Model DRT.15 turbidimeter was used to measure turbidity. The duration of the electrolishing effort was recorded for each pass, and a visual estimate was made of pereent cloud cover. Following completion of fish sampling, the length, widths (at 5-m intervals), and deptlis (at 3 points on the width transect) of the sampling reach were measured at each site.

Species population estimates were calculated using the three-pass removal method of Carle and Strub (1978). Biomass was estimated by multiplying the population estimate by the mean weight per individual. Total numbers and biomass were divided by the surface area $\left(\mathrm{m}^{2}\right)$ of the sampling site to calculate values per unit area. For each sampling date, surface area was estimated by multiplying the length of sampling reach by the mean width based on measurements taken at 5-m intervals (Table 5-1).

The population structure of the three most abundant species was examined by length frequencies. The lengths of the estimated lish population were separated into 1 - or 2-cm size classes, depending on the maximum size of the species. These frequencies indicated whether the population included young and adult individuals and if any unusual mortality had affected a size class. 
Table 5-1. Length, mean width, mean depth, area, and pool-riffle ratio (P/R) of lish sampling sites on McCoy Branch and two reference streams, Grassy Creck and White Oak Croek, for each sampling date

\begin{tabular}{lcccccc}
\hline $\begin{array}{l}\text { Site } \\
(\mathrm{km})\end{array}$ & Date & $\begin{array}{c}\text { Length } \\
(\mathrm{m})\end{array}$ & $\begin{array}{c}\text { Width } \\
(\mathrm{m})\end{array}$ & $\begin{array}{c}\text { Depth } \\
(\mathrm{cm})\end{array}$ & $\begin{array}{c}\text { Area } \\
\left(\mathrm{m}^{2}\right)\end{array}$ & $\begin{array}{c}\text { Pool/ } \\
\text { riffle }\end{array}$ \\
\hline \multirow{2}{*}{ MCK 1.56 } & $(05 / 11 / 89$ & 46 & 1.6 & 18.6 & 74 & 0.4 \\
& $10 / 27 / 89$ & 50 & 0.9 & 10.5 & 45 & 0.4 \\
& $(15 / 16 / 90$ & 50 & 0.9 & 13.6 & 45 & 0.5 \\
GCK 2.4 & $(04 / 06 / 89$ & 60 & 1.9 & 13 & 114 & 0.8 \\
& $10 / 23 / 89$ & 61 & 1.4 & 9 & 85 & 1.8 \\
& $(04 / 19 / 90$ & 61 & 1.6 & 8 & 98 & 0.8 \\
WCK 6.8 & $(14 / 20 / 89$ & 60 & 2.3 & 6.3 & 1.38 & 0.4 \\
& $10 / 31 / 89$ & 60 & 2.0 & 8.1 & 120 & 0.7 \\
& $(14 /(03 / 90$ & 55 & 2.5 & 7.7 & 1.38 & $\mathrm{NM}^{b}$ \\
\hline
\end{tabular}

${ }^{a} \mathrm{MCK}=\mathrm{McCoy}$ Branch kilometer; $\mathrm{GCK}=$ Grassy Creek kilometer; $\mathrm{WCK}=$ White Oak Creek kilometer.

${ }^{b} \mathrm{NM}=$ not measured. 
The procedures used for calculating density, biomass, and longth frequency are given in more detail in Railsback ot al. (1989).

Condition factors measure the degree of plumpness of a lish as a measure of relative health (Bennett 197()). A condition factor (K) was calculated for indivicual fish by site using the following formula:

$$
K=1(K)\left(\text { weight/length }{ }^{3}\right)
$$

where the weight is in grams and total length in centimeters (Hile 1936). Fish without measured weights were not used in the calculation of condition factors. A comparison of condition factors between sampling periods was made with an analysis of variance (ANOVA) on untransformed data (SAS 1985b) because the condition factors exhibited homogeneity of variance (SAS 1985a). If the ANOVA indicated significant differences in condition factors hetween groups, the Tukey test was performed to identify those groups that were signilicantly different (alpha $=0.05)$.

\subsection{RESULTS AND DISCUSSION}

\subsubsection{Community Structure}

Surveys of upper McCoy Branch above Rogers Quarry failed to locate any fish. The three surveys at MCK 1.56 indicated the stream below the quarry had a permanent fish eommunity. Al MCK 1.56, species richness (total number of species) ranged from 9 to 11 species for the three surveys made from May 1989 to May 1990) (Table 5-2). The total number of species taken during this period was 14, but only 6 species were taken in all surveys. Species richness in McCoy Branch was considerably higher than the 3-5 species found in the reference sites.

The variability in species number and eomposition in MeCoy Branch is related to proximity of the site (o) Melton Hill Reservoir. The closeness of the reservoir allows species to be found in McCoy Branch that are atypical for a stream the size of McCoy Branch. Only blacknose dace (Rhinichthys atratulus), central stoneroller (Campostoma (tnomalum), redhreast sunfish (Lepomis auritus), and snubnose darter (Etheostoma simoterum) are typical inhabitants of similar-sized streams in this area (Ryon and Loar 1988). Comparisons with the reference streams indicate that several species expected to occur in streams of this size were missing. These species include creek chub (Semotilus atromaculatus), striped shiner (Luxilus chrysocephalus), white sucker (Catostomus commersoni), and banded sculpin (Cottus carolinae). The absence of these species may reflect past extermination by coal ash discharges and prevention of recolonization from Melton Hill Reservoir. The variable association of fish species and the presence of fish atypical for a stream of this size suggest that the community contains many individuals that move in and out from the reservoir.

The fish community at MCK 1.56 contained four species /green sunfish ( $L$. cyanellus), carp (Cyprinus carpio), yellow bullhead (Ameiurus natalis), and spotfin shiner (Cyprinella spilopter(a)] that are considered to be insensitive to many habitat and water 
Table 5-2. Fish densities (number fish/ $\mathrm{m}^{2}$ ) in McCoy Branch and in two reference streams, Whitc Oak Creek and Grassy Creck, for April-May 1989 to April-May 1990

\begin{tabular}{|c|c|c|c|}
\hline Species & $\begin{array}{c}\text { April-May } \\
1989\end{array}$ & $\begin{array}{c}\text { October } \\
1989\end{array}$ & $\begin{array}{c}\text { April-May } \\
1990\end{array}$ \\
\hline \multicolumn{4}{|c|}{ McCoy Branch kilometer 1.56} \\
\hline Blacknose dace & & $<0.1^{a}$ & \\
\hline Bluntnose minnnow & 0.5 & 0.7 & 0.1 \\
\hline Carp & 0.1 & & \\
\hline Spotfin shiner & 0.1 & & \\
\hline Stoneroller & $<0.1$ & & \\
\hline Bluegill sunfish & 5.2 & 0.4 & 1.4 \\
\hline Green sunfish & 0.3 & 0.9 & 0.8 \\
\hline Largemouth bass & & 0.1 & $<0.1$ \\
\hline Redbreast sunfish & 0.1 & 0.2 & $<0.1$ \\
\hline Redear sunfish & $<0.1$ & $<0.1$ & \\
\hline Warmouth & & 0.1 & $<0.1$ \\
\hline Greenside darter & $<0.1$ & & $<0.1$ \\
\hline Snubnose darter & $<0.1$ & 0.1 & $<0.1$ \\
\hline Yellow bullhead & $<0.1$ & 0.2 & 0.1 \\
\hline Total number species & 11 & 10 & 9 \\
\hline Total density & 6.4 & 2.7 & 2.6 \\
\hline \multicolumn{4}{|c|}{ White Oak Creek kilometer 6.8} \\
\hline Blacknose dace & 1.0 & 1.9 & 1.1 \\
\hline Creck chub & 0.1 & 0.2 & $<0.1$ \\
\hline Stoneroller & & $<0.1$ & \\
\hline Banded sculpin & 0.2 & 0.3 & 0.3 \\
\hline Total number of species & 3 & 4 & 3 \\
\hline Total density & 1.3 & 2.4 & 1.4 \\
\hline \multicolumn{4}{|c|}{ Grassy Creek kilometer 2.4} \\
\hline Blacknose dace & 0.1 & 2.2 & 0.9 \\
\hline Creck chub & 0.1 & 0.5 & 0.3 \\
\hline Striped shiner & $<() .1$ & & $<0.1$ \\
\hline Green sunfish & & $<0.1$ & \\
\hline White sucker & $<0.1$ & $<0.1$ & $<0.1$ \\
\hline Banded sculpin & & $<0.1$ & $<0.1$ \\
\hline Total number of species & 4 & 5 & 5 \\
\hline Tolal density & (). 2 & 2.8 & 1.3 \\
\hline
\end{tabular}

${ }^{a}$ Value of $<0.1$ indicates species was present at very low densitics. 
quality stressors. They would be considered tolerant species in an impact assessment methodology such as the Index of Biotic Integrity (Karr et al. 1986). Only two species were found that would be considered slightly intolerant or sensitive to stress, the Tennessee snubnose darter and greenside darter ( $E$. blenniodes), and these species were represented by only a few individuals. This pattern suggests that McCoy Branch is a stressed system.

Trophic composition of the community can indicate further stress on the system. A nonimpacted stream will have many benthic insectivores, few generalist feeders, and a stable piscivore population. The fish community of McCoy Branch included many omnivores or generalist feeders, few benthic insectivores, and fewer piscivores. Generalist fecders are readily able to switch prey items and are more successful in stressed stream systems (Leonard and Orth 1986). In McCoy Branch the generalist feeders included the blacknose dace, carp, bluegill sunfish (L. macrochirus), warmouth (L. gulosus), and yellow bullhead. Benthic insectivores are specialized feeders that are limited in the prey items they can eat, are more successful in undisturbed streams (Leonard and Orth 1986), and in McCoy Branch, included only the two darter species. The largemouth bass (Micropterus salmoides) was the only piscivore; it was present in low numbers (Table 5-2) and only at small sizes.

\subsubsection{Population Densitics}

Densities at MCK 1.56 for the three sampling periods ranged from 2.6 to $6.4 \mathrm{lish} / \mathrm{m}^{2}$ (Table 5-2). The density in May 1989 of $6.4 \mathrm{fish} / \mathrm{m}^{2}$, included $5.2 \mathrm{bluegill} / \mathrm{m}^{2}$. Later samples did not have such a strong component of bluegills, and the densities were much lower. Comparei with reference streams, MCK 1.56 densities were generally higher than either densities at GCK 2.4 or WCK 6.8. The high densities may be affected by immigration from Melton Hill Reservoir and/or Rogers Quarry.

The densities of individual species were proportionally similar for each sampling period. The eommunity density was dominated by bluntnose minnow, bluegill, and green sunfish; however, none of these species occurred in the reference streams. Conversely, the dominant species in the reference streams, blacknose dace and creek chub, were present in low numbers or absent altogether from McCoy Branch.

\subsubsection{Population Biomass}

Fish biomass values (g wet $\mathrm{wt} / \mathrm{m}^{2}$ ) paralleled the trends observed in population density (Table 5-3). The initial sample in May 1989 had an extremely high biomass of $107.5 \mathrm{~g} \mathrm{wet} \mathrm{wt} / \mathrm{m}^{2}$ and was due to the presence of several large carp and a substantial number of sunfish. The sample in October 1989 had a much lower biomass (17.4 g wet $\mathrm{wt} / \mathrm{m}^{2}$ ) than in May' (itue to the absence of many large sunlish. However, the eommunity hiomass rebounded in May 1990 (50.3 $\mathrm{g}$ wet wt $/ \mathrm{m}^{2}$ ), when more large sunfish returned to the site. The biomass in McCoy Branch was 2-10) times higher than the values found in the reference streams (Table 5-3) at comparable sampling dates.

The dominant species (excluding carp), in terms of biomass, were bluegill, green, and redbreast sunfish. Most of the biomass for bluegill and green sunfish came from large numbers of several incermediate size classes, while the biomass of the redbreast sunfish 
Table 5-3. Fish biomass ( $\mathrm{g}$ fish $/ \mathrm{m}^{2}$ ) in McCoy Branch and in two reforence streams, Whitc Oak Creck and Grassy Creck, for April--May 1989 to April--May 1990)

\begin{tabular}{cccc}
\hline Species & $\begin{array}{c}\text { April-May } \\
1989\end{array}$ & $\begin{array}{c}\text { October } \\
1989\end{array}$ & $\begin{array}{c}\text { April-May } \\
199()\end{array}$ \\
\hline
\end{tabular}

McCoy Branch kilometer 1.56

Blacknose daco

Bluntnose minnnow

Carp

Spotfin shiner

Sioneroller

Bluegill sunfish

Green sunfish

Largemouth bass

Redbreast sunfish

Redear sunfish

Warmouth

Greenside darter

Snubnose darter

Yellow bullhead

Total biomass

$\begin{array}{rrr} & 0.1 & \\ 1.7 & 0.9 & 0.2 \\ 74.6 & & \\ 0.5 & & 35.8 \\ 0.1 & 3.1 & 6.2 \\ 20.1 & 1.8 & 0.3 \\ 3.9 & 0.8 & 2.3 \\ & 6.7 & \\ 6.1 & 0.5 & 0.6 \\ 0.2 & 0.9 & 0.3 \\ 0.1 & & 0.1 \\ <0.1 & 0.2 & 4.5 \\ 0.2 & 2.4 & 50.3 \\ 107.5 & 17.4 & \end{array}$

White Oak Creek kilometer 68

Blacknose dace

Creck chub

Stoneroller

Banded sculpin

Total biomass
1.3

0.4

1.0

2.7
8.4

1.2

0.1

$<0.1$

1.2

0.9

9.9

2.2

Grassy Creek kilometer 2.4

Blacknose dace

Creck chub

Striped shiner

Green sunfish

White sucker

Banded sculpin

Total biomass
0.2

0.4

(). 1

0.2

0.9
1.5

2.1

1.1

1.6

0.5

0.7

0.2

$0 . .3$

0.6

$<0.1$

5.1 
was based on a lew large individuals. The dominance by sunfish of the community biomass reflected the influence of Melton Hill Reservoir.

\subsubsection{Length Frequency}

The length-ifequency histograms for the three most abundant species reflected their reproductive patterns and any potential stress from coal ash on these patterns. The most abundant species, the bluegill sunfish, showed a strong dominance by the $4-107.9-\mathrm{cm}$ size classes in the spring 1989 sample (Fig. 5-1). However, the fall 1989) sample does not show any small size classes, suggesting a lack of bluegill reproduction in McCoy Branch. Also the general blucgill population declined. In 1990), the population remained small with a shilt towards more large individuals in the site.

The green sunfish showed a more balanced pattern, with large numbers of small- to medium-sized individuals and a few large individuals at all sample dates (Flg. 5-1). In the fall 1989 sample, the two smallest size classes had substantial numbers of fish. This suggests a relatively stable reproductive effort.

The bluntnose minnow had a much narrower size range, which was dominated by larger size classes in the spring samples (Fig. 5-1). The smaller individuals in the fall 1989 sample are an indication of some reproduction (or immigration from nearby embayment areas).

\subsubsection{Condition Factors:}

Comparisons of condition factors $(\mathrm{K})$ should provide information on the relative wellbeing of the fish, because those with more weight per length have a higher condition factor (Everhart :t al. 1975). Data were not available for a statistical comparison of condition factors between MCK 1.56 and the reference sites because there was so little species overlap. When compared with condition factors of redbreast and bluegill sunfish in other areas of WOC (M. G. Ryon, Environmental Sciences Division, ORNL, personal communication), condition factors of these species at MCK 1.56 were within the range of values. Seasonal comparisons of condition factors in McCoy Branch were made for nine species. Three species, bluegill sunfish, green sunfish, and bluntnose minnow demonstrated statistically greater condition factors in spring samples than in fall samples. Six other species did not show any significant differenecs.

\subsubsection{Observed Abnormalitics}

As part of the normal processing procedure for population estimates, observations of abnormalities or attached parasites are made of the lish specimens. Usually, these abnormalities are limited to less than $1-5 \%$ of the population in a minimally stressed system; a highly stressed system would have $5 \%$ or more abnormalitics (Karr et al. 1986). Such abnormalities may include spinal deformities, open skin lesions, fin rot or erosion, or distended eyes ("popeye'). The number of such observations made in MeCoy Branch secmed unusually high. 

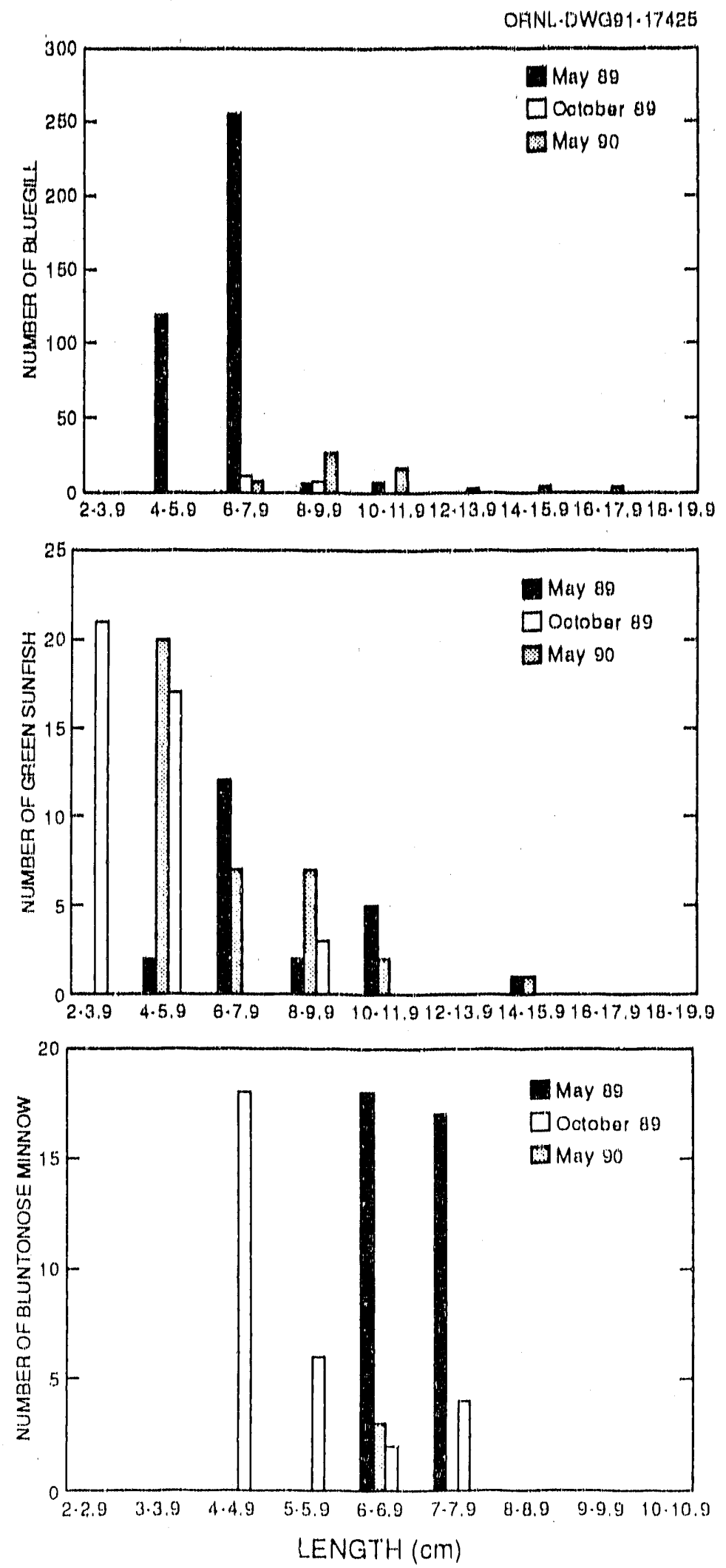

Fig. 5-1. Iength-frequency histograms for blucgill sunfish, green sunfish, and bluntnose minnow for May 1989, October 1989, and May 1990) from McCoy Branch site MCK 1.56. 
In the May 1989 sample, 27\% of' the greon sunflah (6.3-1.5.7 mm 'Th) and $7.3 \%$ of' the redbreast sunfish $(10.9-17.5 \mathrm{~mm} \mathrm{TL}$ ) had one abnormally, extremely croded fins. The pelvic, pectomal, and andil fins were oflen missing or reduced to mero lin rays wilhoul any membranes and tipped by an enlarged knob. The oceurrence of abnormalliks decrensed substandially in the Ocobor 1989 listh population sumple $(2 \%)$. However, the May 199() sample ngain demonstrated severe abnormalites. Eroded lins wore found. In $8 \%$ of the green suntish $(9.1-14.5 \mathrm{~mm}$ TL) and $1.3 \%$ of the blueglll sunlish. Also, $11 \%$ of' the bluegill (9.2-18.1 mm Th) showed another ubnormallty, 1 misshaponed head that appeared to be a skull delormily. Similar deformlties were noted in largemouth hass laken in hioaccumulation sumpling of' Rogers Quarry (Seci, 4.3), Tho reference streams did not have any specimens with either ereded fins or deformed hoads during these sumpling periods. 'The presence of the deformltess suggests an extreme stress in MaCoy Branch, perhaps related to the high levels of arsente or selenlum in McCoy Branch water (Sect, 2.2.2 and 4.3).

\subsection{CONCLUSIONS}

Data on the fish populations of MaCoy Branch demonstrated the stream has recelved considerable stress from the coal ash operations. 'The otal lack of species above the quarry indicate that conditions were lethal to fist in that section. The cessation of the coul ash sluiding through thall section alter November 1989 should have reduced that stress. However, Rogers Quarry effectively acts as a migration barricer to species that might repopulate upper McCoy Branch.

The lish community below Rogers Quarry, although permanent, demonstrates a lesser degree of impact than that of upper MeCoy Branch. The stress is related to both eoal ash discharges and the impacts of Melton Hill Reservolt. 'The species composition, and the most ubundant species, reflect conditions inappropriate for a stream the size of MoCoy Branch. Species thut should oceur in such a stream are missing and have been replaced by these from the adjacent reservoir. Even those species demonstrate several degrees of stress. The species oceurring in the stream include those most tolerant of elegraded conditions. This applies to both tolerance of physical and chemical stress and a llexibility in leceling, recpuirements. Finally, substantial numbers of individuals within the eommunity demonstrate severe physical abnormalities only rarely found in othor systems.

\subsection{IUTURE STUDIFS}

The future plans for assessing the flish community in MeCoy Branch will continue the twice a year (sppring and fiall) sampling schedule. Until lissh populations are found in upper MeCoy Branch, sampling in that area will be restricted to qualitalive surveys. An additional reference sile: will be sampled quantitalively. This selerded site will more clescly approximate the species and the enditions of MCK 1.56. For example, the site will be situaled close 10 an embayment or main section of Mellon Hill Reserveir. During the quantibative processing additional allention will he given lo assessing abnormalities. 


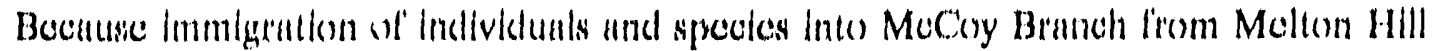
Reservole is oceurring, larther qualitalles sumpling will be conducted to assess

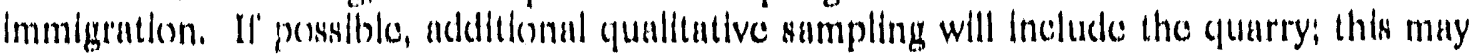
be a cooperative elfert with sampling for the bionceumulation task.

Longuterm plans for McCoy Branch studies may include the reintroduction of lish spocies Into upper MeCoy Branch above Rogers Quarry, The lish would be species expested to ocesur tri such a stream (c,g, blacknose dace) and population dynamics would be monitored aller the esintroduction. 


\section{BEN'THIC MAClKOINVIERTEBBRATE COMMUNITY ASSIESSMENT'}

\subsection{INTRODUCIION}

Benthic mucrelinvertebrales are these organisms which llve on or in the substrute of llowing and nonflowing bodies of water and are large enough to be seen without the aid of magnificatlon. Their limited mobility and relatively long life spans (a lew months to more than a your') ol' most laxa make them ideal lor evaluating the ecological ofl'eds of colthent discharges (o) streams (Platts et al. 1983). Thus, the composition and structure of the benthic community reflect the rolatively recent past, and they can be considerably more Informative than ulternative methods that rely solely on water quality analyses but miss the potential synergistic eflects often associated with complex effluents. The objective of the initial phase of' this study is to provide a detailed spatial and temporal characterization of the benthic invertebrate community of McCoy Branch. These data will be used as a baseline from which the effectiveness of major remedial actions within the MeCny Branch walcershod can be assessed. The data will also be used to provide direction for' f'uture studles.

\subsection{MATERIALS AND METHODS}

Benthic macroinvertebrates were sampled at approximately quarterly intervals boginning in April 1989 through January 19k) at two sites in MoCoy Branch (Fig, 2-2). Because an unimpacted reforence site was not available on McCoy Branch, a relatively unimpacted reach ol' upper WOC served as a referenoe site. Upper WOC is similar in size to MoCoy Branch, and is located just north of ORNL, approximately $3 \mathrm{Km}$ west of MeCoy Branch (Fig. 2-1). Three random quantitative samples were collected from a permanently marked riffle at each site with a Surber bottom sampler $\left(0.09 \mathrm{~m}^{2}\right)$ litted with a $36.3-\mu \mathrm{m}$-mesh collection net. "To obtain additional information on taxonomic richness, a yualitative sample consisting of collections from riffle and nonrifle habitats (e.g., pools, loal' packs, detritus, and snigs) was taken from each site in spring 1989. Qualitative samples were collected with a D.lrame aquatic dip net (mesh of $8(M) \mu \mathrm{m} \times 9(\%) \mu \mathrm{m})$. All samples were placed in prelabeled, polyurethane-coated glass jars and preserved in $80 \%$ cthanol; the ethanol was replaced with lresh ethanol (80\%) within $10 \mathrm{~d}$ of collection.

Supplemental information on water quality and stream characteristics was recorded at the time of sampling. Temperature, conductivity, dissolved oxygen, and pH were measured with an Horiba Model U-7 Water Quality Checker. Water depth, location within the rifle area (distane from permanent headstakes on the stream bank), visual determinalion of relative stream velocity (very slow, slow, moderale, or fast), and substrate type |visual determinalion based on a modilied Wentworth particle size scale (Loar 1985)] were recorded lor each sample.

All samples were washed in the laboratery using a U.S. Standard Series No, 60) sicve (2.5()- $4 . \mathrm{m}$ mesh) and placed in an 8- $\mathrm{x} 1(1)$ inch white, plastic tray for sorting. Organisms were removed from the debris with forceps and placed in labeled vials containing 8()$\%$ ethanol. Organisms were identified on the lowest practical taxonomic level using a 
sterooscopic dissecting microscope. After chironomid larvac were sorted into groups based on morphologleal similarltes, one or more representatives of each group were mounted on a slide in CMC-10 mounting medium and identilied using a compound microscope. The remaining chilronomid larvae were then identified at a magnification of 5()X to 1(K)X with a dissecting microscopse. A blotted wet weight of all individuals combined In each taxon was determined to the noarest $0.01 \mathrm{mg}$ on a Mettler analytical bulance.

Slides of mounted chironomid larvae were retained in slike boxes, and individuals of the remaining taxa from a given site and sampling date were preserved in separate vials containing $80 \%$ ethand. A reference collection of these specimens will be maintained at ORNL.

'The Shannon-Welner index $\left(\mathrm{H}^{\prime}\right)$ was used to calculate the taxonomic diversity of' benthic macroinvertebrates at each site (Pielou 1977):

$$
\mathbf{H}^{\prime}=-\sum \mathbf{p}_{j} \log _{2} \mathbf{p}_{j}
$$

where $P_{j}$ is the proportion of the benthic invertebrate community made up of species $j$. $H^{\prime}$ values of 3 or greater are typical of clean water, while values of $1-3$ are usually associated with moderate pollution, and values of less than 1 characterize heavily polluted water (Platts et al, 1983).

All data analyses were done with the Statistical Analysis System (SAS 1985a,b). Mean values for density'; biomass'; number of taxa per sample (taxonomic richness); number of Ephemeroptera, Plecoptera, and Trichoptera taxa per sample (EPT richness); and taxonomic diversity were compared separately with a one-way analysis of variance (ANOVA) on quarterly sampling period-specific data with site as the main effect; all analyses were based on three replicates per site and date. Prior to performing the ANOVAs, data were transformed

$$
\log 10(X+1)
$$

where $X=$ inclividual values for density, biomass, etc. (Elliott 1977). Where significant differenees were found hetween sites, treatment means were compared using a Tukey standardized range test $(\alpha=0,05)$ lo discriminate these differences.

\footnotetext{
${ }^{1}$ Comparisons between sites in density and biomass were made both with and without Mollusca (snails and mussels) and Decapoda (crayfish) since these taxa are typically very heavy but numerically unimportant and can thus suppress the importance of the weight changes of the other organisms. Therefore, unless otherwise noted, trends presented in both spatial and temporal patterns in density include both Decapoda and Mollusca, while trends in biomass exclude these two groups.
} 


\subsection{RESULTS}

\subsubsection{Taxonomic Composition}

A checklist of the benthic invertebrates collected from McCoy Branch and a reference site at WCK 6.8 from April 1989 through January 1990, is presented in Appendix B, Table B-1. A total of 163 distirct taxa, 145 of which were insects, were collected in quantitative samples from the designated sampling sites in the two streams. Nine orders of insects, including Collembola (springtails), Ephemeroptera (mayllies), Coleoptera (beetles), Diptera (true flies), Hemiptera (true bugs), Megaloptera (aldertlies, fishflies, and dobsonflies), Odonata (dragonflies and damselflies), Plecoptera (stoneflies), and Trichoptera (caddisflies), were collected from these streams. The order Diptera was the most taxonomically rich group with 76 representative taxa, 50 of which were from the family Chironomidae (true midges). Of the remaining insect orders, Trichoptera, Ephemeroptera, and Plecoptera had the greatest number of taxa with 23, 20, and 16 taxa, respectively. The numbers of taxa from these three orders were greater from the reference site than from either of the two McCoy Branch sites. Of the nine insect orders represented in the quantitative samples, Megaloptera were absent from MCK 1.40, and Hemiptera were absent from MCK 2.03.

In addition to insects, taxa representing ten other major taxonomic groups were collected including Amphipoda (sideswimmers), Copepoda (copepods), Decapoda (crayfish), Gastropoda (snails). Hydracarina (water mitcs), Nematoda (roundworms), Oligochacta (aquatic earthworms), Ostracoda (seed shrimp), Bivalvia (mussels and clams), and Tricladida (planaria or flatworms) (Appendix B, Table B-1). Copepoda and Ostracoda were collected only from McCoy Branch.

Twenty-seven additional taxa were collected from McCoy Branch and 25 from WOC in qualitative samples (Appendix B, Table B-1). Decapods, amphipods, and water mites were found in McCoy Branch only in the qualitative samples (Appendix B, Table B-1). Of the additional taxa collected from McCoy Branch, only one belonged to the order Ephemeroptera. In the WCK 6.8 sample, there were 11 additional laxa of Ephemeroptera, Plecoptera, and Trichoptera. The group containing the greatest number of additional taxat was the dipterans ( 7 from WCK 6.8 and 23 from the MCK sites).

\subsubsection{Density and Biomass}

The annual means for density and hiomass of the benthic macroinvertebrates at each sampling site are presented in Table 6-1. The density of invertebrates (including and excluding mollusks and decapods) at MCK 1.40 ) and WCK 6.8 was almost twice that at MCK 2.03 (Table 6-1); these differenees were statistically significant (Table 6-2). The biomass of macroinvertebrates (all taxa) at WCK 6.8 was more than 13 times higher than at MCK 2.03, and almost 6 times higher than at MCK 1.40 (Table 6-1). When mollusks and decapods were excluded, the biomass at WCK 6.8 was similar to the biomass at MCK 1.40 but still was almost 2.5 times higher than at MCK 2.03. Statistical comparisons showed that the biomass at MCK 2.03 was significantly lower than at MCK 1.40 and WCK 6.8 (with or without the mollusks and decapods), while the biomass at MCK 1.40) differed from WCK 6.8 only when all laxa were considered (Table 6.2). 


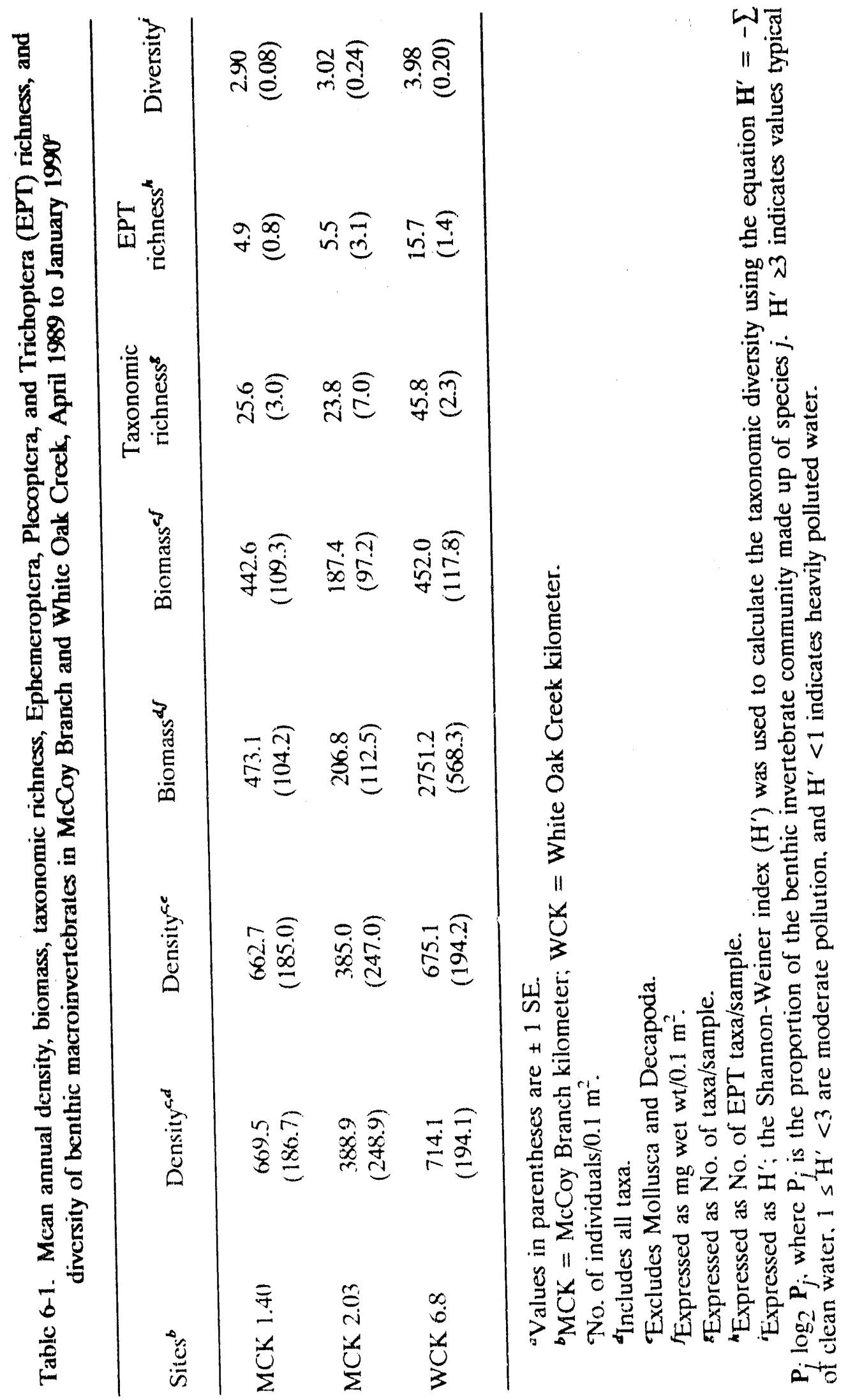


Table 6-2. Statistical comparisons ${ }^{a}$ of mean annual benthic macroinvertebrate density, biomass, taxonomic richness, Ephemeroptera, Plectoptera and Trichoptera (EPT) richness, and species diversity in McCoy Branch ${ }^{b}$ and the reference stream, White Oak Creek ${ }^{c}$

Parameter type

Density (all taxa)

WCK 6.8 $\quad$ MCK 1.40 $\quad$ MCK 2.03

Density (cxcluding Mollusca and Decapoda)

WCK $6.8 \quad \underline{M C K ~} 1.40 \quad \underline{M C K ~} 2.03$

Biomass (all taxa)

$\underline{\text { WCK } 6.8} \quad \underline{\text { MCK } 1.40} \quad \underline{\text { MCK 2.03 }}$

Biomass (excluding Mollusks \& Decopoda)

$\underline{\text { WCK } 6.8 \quad M C K ~ 1.40 ~} \quad$ MCK 2.03

Richness

WCK $6.8 \quad$ MCK $1.40 \quad$ MCK 2.03

EPT Richness

WCK 6.8 MCK $1.40 \quad$ MCK 2.03

Diversity

WCK 6.8 $\quad$ MCK 1.40

\footnotetext{
${ }^{a}$ Sites not joined by lines are significantly different $(\alpha=0.05)$, based on Tukey's studentized range test (HSD). $\mathrm{n}=12$ for each site.

${ }^{b} \mathrm{McCoy}$ Branch kilometer $=\mathrm{MCK}$.

${ }^{c}$ White Oak Creek kilometer $=$ WCK.
} 
Temporal patterns in density of macroinvertebrates at MCK 1.40 and WCK 6.8 were similar with the highest density at both sites occurring in July 1989 (Fig. 6-1). In contrast, the greatest density at MCK 2.0.3 occurred in January 1990 when the density was four times greater than during the previous three sampling periods. During each sampling period, chironomids and coleopterans were generally the most abundant taxa at MCK 1.40, although a July peak in density was primarily the result of a substantial increase in the numbers of trichopterans and nonchironomid dipterans. Chironomids, ephemeropterans, and plecopterans were consistently the most abundant taxa at WCK 6.8. The July peak in density at this site resulted primarily from an increase in the numbers of ephemeropterans and nonchironomid dipterans and to a lesser extent plecopterans and chironomids (Fig. 6-2). Chironomid densities were generally higher than the densities of other taxa at MCK 2.03; however, ephemeropterans (primarily Baetis) were responsible for a dramatic increase in density at this site in January.

Seasonal trends in biomass were similar to those of density, with the highest values for biomass at MCK 1.40 and WCK 6.8 occurring in July, and the highest value at MCK 2.03 occurring in January (Fig. 6-1). Seasonal changes in biomass at MCK 1.40 largely reflected the seasonal changes of Trichoptera, while at MCK 2.03 and WCK 6.8 several taxa, particularly Trichoptera and Diptera, contributed to the seasonal changes (Fig. 6-3).

\subsubsection{Community Structure}

\subsubsection{Taxonomic Richness}

The number of taxa collected per sample at WCK 6.8 was almost two times greater than at either McCoy Branch site; this difference was statistically significant (Tables 6-1 and 6-2). Taxonomic richness at the two McCoy Branch sites was similar, although the much higher standard error at MCK 2.03 demonstrated that fluctuations in richness between sampling periods were considerable. In contrast, richness at MCK 1.40 and WCK 6.8 remained relatively stable.

Temporal changes in taxonomic richness were similar at MCK 1.40 and WCK 6.8 with each site exhibiting both increases and decreases through time (Fig. 6-4). In contrast, laxonomic richness at MCK 2.03 increased considerably through time with the January 1990 value being four times as high as the value than in April 1989. Notwithstanding these between-site differences, all three sites exhibited peaks in richness in January.

\subsubsection{EPT Richness}

Mean Ephemeroptera, Plecoptera, and Trichoptera (EPT) richness for all sampling periods was significiantly greater in WOC than in either McCoy Branch site (Tables 6.1 and 6-2). The mean number of EPT taxa at the WCK 6.8 site was three times that of either McCoy Branch site. Mean EPT richness at the two McCoy Branch sites was similar, although variability between sampling periods was considerably greater at MCK 2.03. 

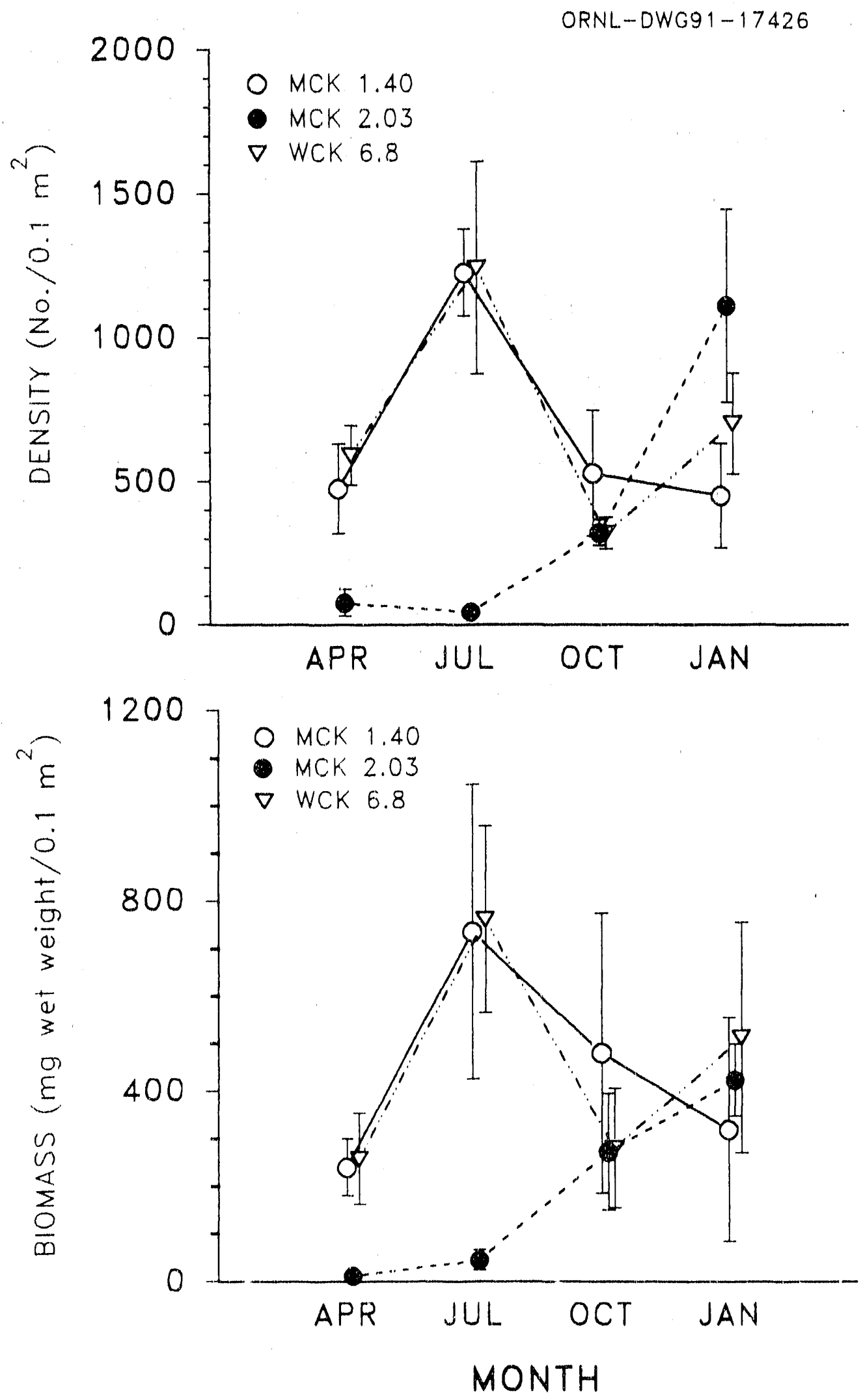

Fig. 6-1. Mean scasonal density (all taxa) and biomass (excluding Mollusca and Decapoxla) of benthic macroinvertebrates in McCoy Branch and White Oak Creck, April 1989 to January 1990. Vertical hars are $\pm 1 \mathrm{SE}$. MCK $=$ McCoy Branch kilometer and WCK $=$ White Oak Creek kilometer. 

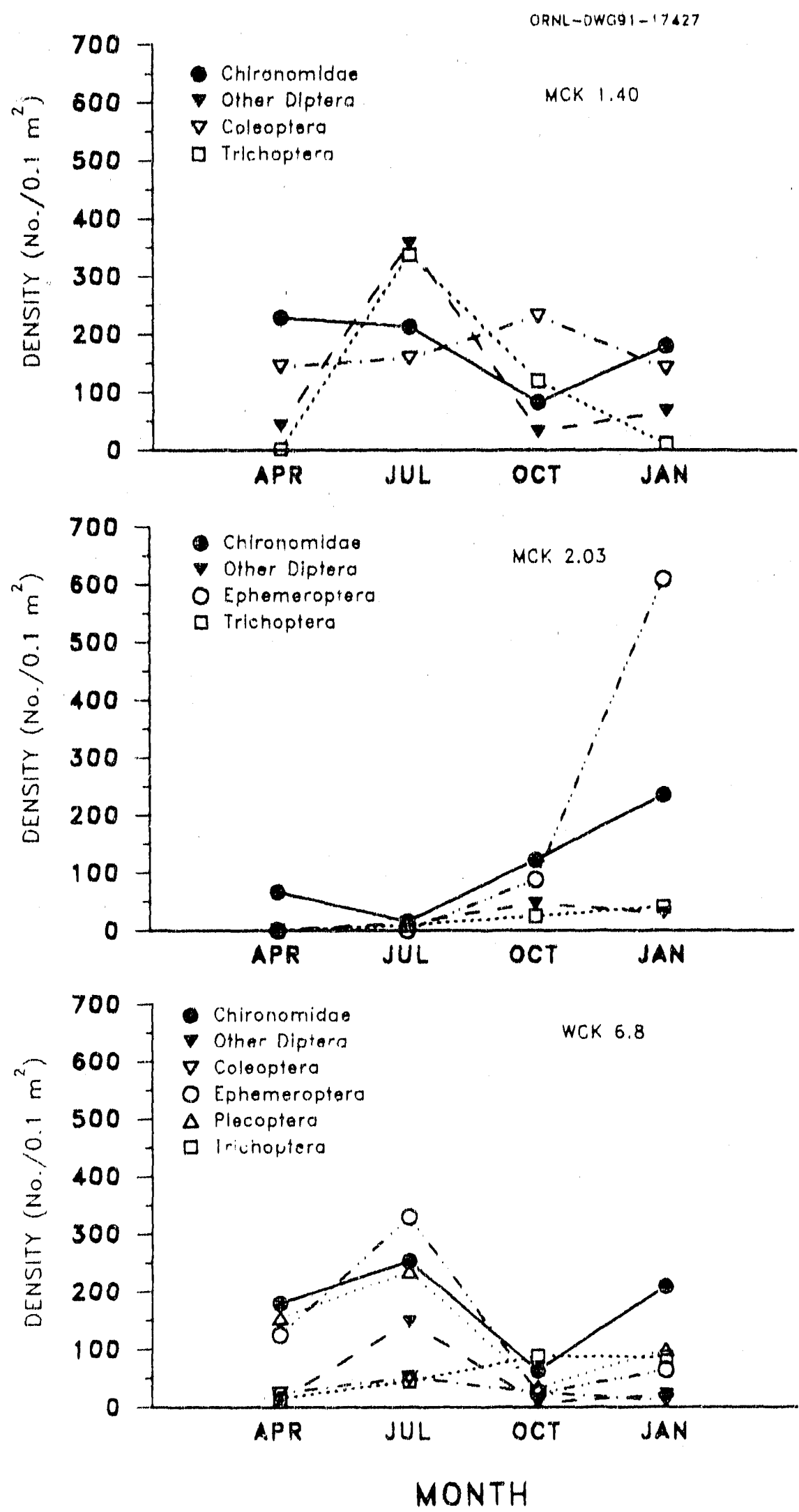

Fig 6-2. Mean scasonal density (No. of individuals $/\left(0.1 \mathrm{~m}^{2}\right.$ ) for selected taxa in McCoy Branch and Whitc Oak Creck, April 1989 to January 1990. MCK = McCoy Branch kilometer and WCK = White Oak Creck kilometer. 

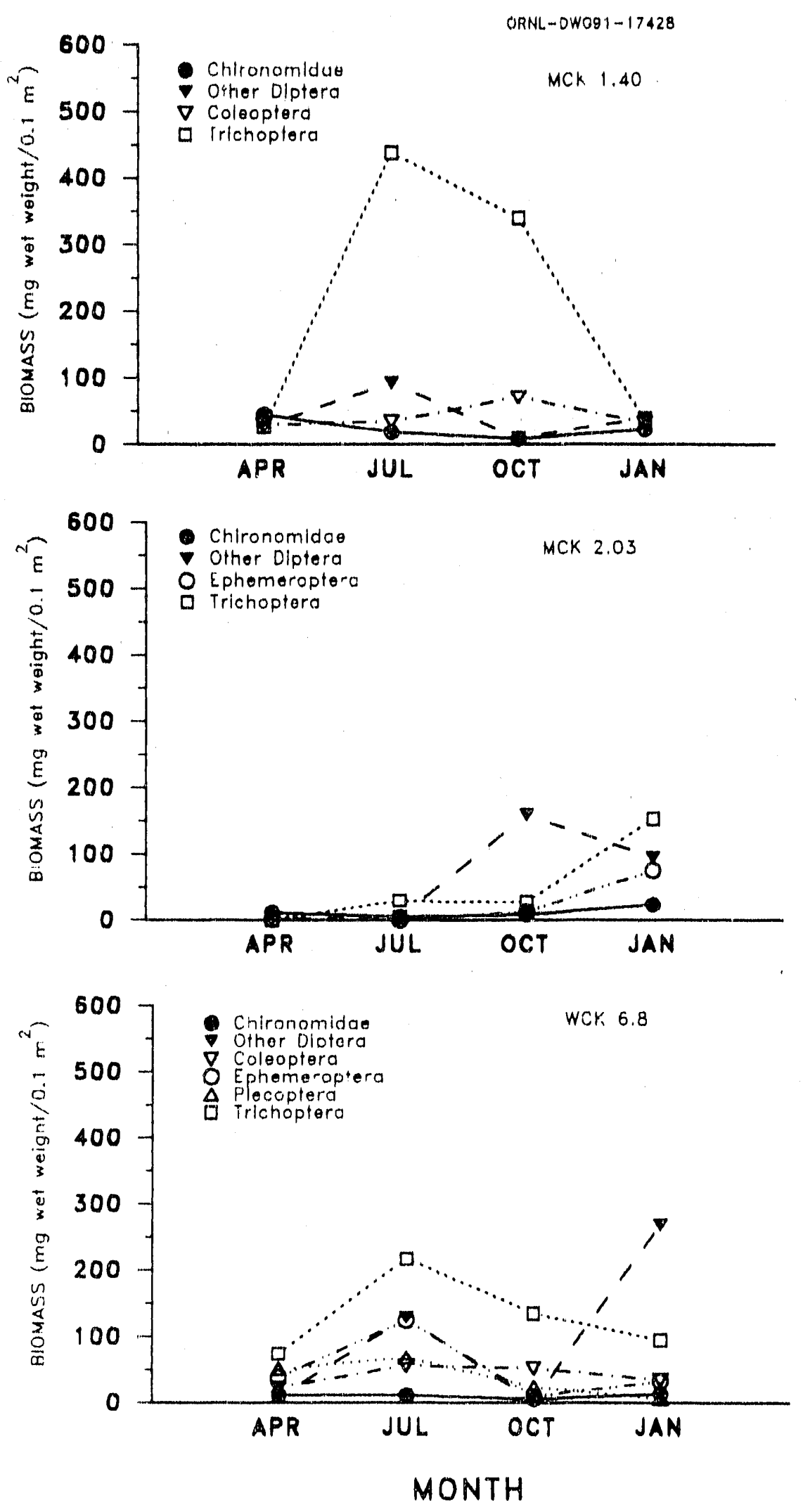

Fig 6-3. Mcan scasonal biomass (mg wet wt./0.1 $\mathrm{m}^{2}$ ) for sclected taxa in McCoy Branch and White Oak Creck, April 1989 to January 1990). MCK = McCoy Branch kilometer and WCK = White Oak Creek kilometer. 


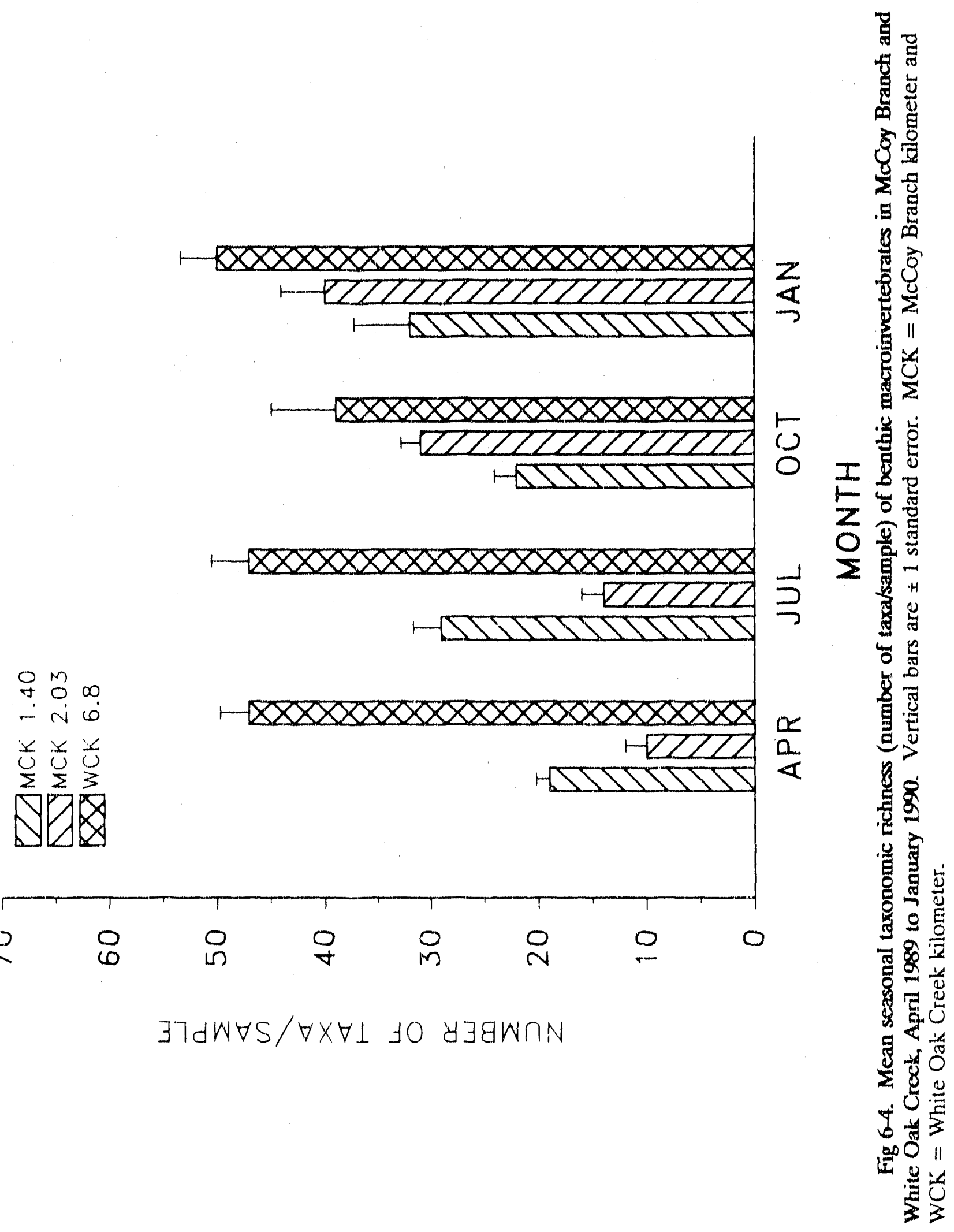


EPT taxa were collected from all sites during all sampling periods (Fig. 6-5). The richness of these taxa was particularly low at MCK 2.03 in April and July when an average of fewer than two EPT taxa were collected in each sample. As with taxonomic richness, the mean number of EPT taxa from WCK 6.8 was always higher than at either McCoy Branch site. The number of EPT taxa remained relatively stable through time at WCK 6.8 and MCK 1.40 , while the greatest variability between sampling periods was exhibited at MCK 2.03.

\subsubsection{Species Diversity}

Spatial patterns in taxonomic diversity $\left(\mathrm{H}^{\prime}\right)$ were similar to those observed for taxonomic and EPT richness (Table 6-1); diversity was significantly higher at WCK 6.8 than at either McCoy Branch site while at the two McCoy Branch sites diversity was similar (Table 6-2). Also, as for taxonomic and EPT richness, diversity was highest at WCK 6.8 during all sampling periods (Fig. 6-6). Temporally, MCK 1.40 exhibited less dramatic fluctuations in diversity than the other two sites, staying close to 3.0 in all sampling periods (Fig. 6-6). The other two sites exhibited similar magnitudes of fluctuation between each sampling period although not the same patterrs.

\subsection{DISCUSSION}

The benthic invertebrate community of McCoy Branch, which historically has received fly ash and bottom ash sluiced from the stearn plant at the Oak Ridge Y-12 Plant, exhibited evidence of moderate degradation of water quality and/or physical habitat. Relative to the reference site on White Oak Creek (WCK 6.8), both McCoy Branch sites exhibited significantly lower values for taxonomic and EP'T richness, and diversity. Additionally, both density and biomass were significantly lower at MCK 2.03 than at WCK 6.8 and MCK 1.40, suggesting that a greater degree of degradation exists upstream of Rogers Quarry. The most notable differences between the reference site and both McCoy Branch sites were in taxonomic and EPT richness; taxonomic richness was two times higher and EPT richness at least three times higher at WCK 6.8. The greater number of EPT taxa at WCK 6.8 is indicative of the overall health of this site, because EP'T taxa generally tend to be very sensitive to alterations in water quality and physical habitat (Wiederholm 1984; Lenat 1984; Lenat 1988).

Smith (1991a) found that the most highly-stressed invertebrate communities in streams on or near the ORR are alrnost exclusively comprised of chironomids and/or oligochactes, while less pollution-tolerant EPT taxa are virtually absent. While EPT richness was reduced in McCoy Branch relative to WCK 6.8, EPT taxa were collected during each sampling period from both sites. Although the EPT values from the McCoy Branch sites are consistently lower than for sites in other relatively undisturbed streams that drain the south slope of Chestnut Ridge near ORNL (J. G. Smith, Environmental Sciences Division, ORNL, personal eommunication), the EPT values are comparable to those of a relatively undisturbed reach of Mitchell Branch (MIK 1.43) located just cast of the Oak Ridge K-25 Site (J. G. Smith, Environmental Sciences Division, ORNL, personal communication). This suggests that the degree of stress to the benthic macroinvertebrate community in McCoy Branch is relatively moderate. Greater stress at MCK 2.03 relative 


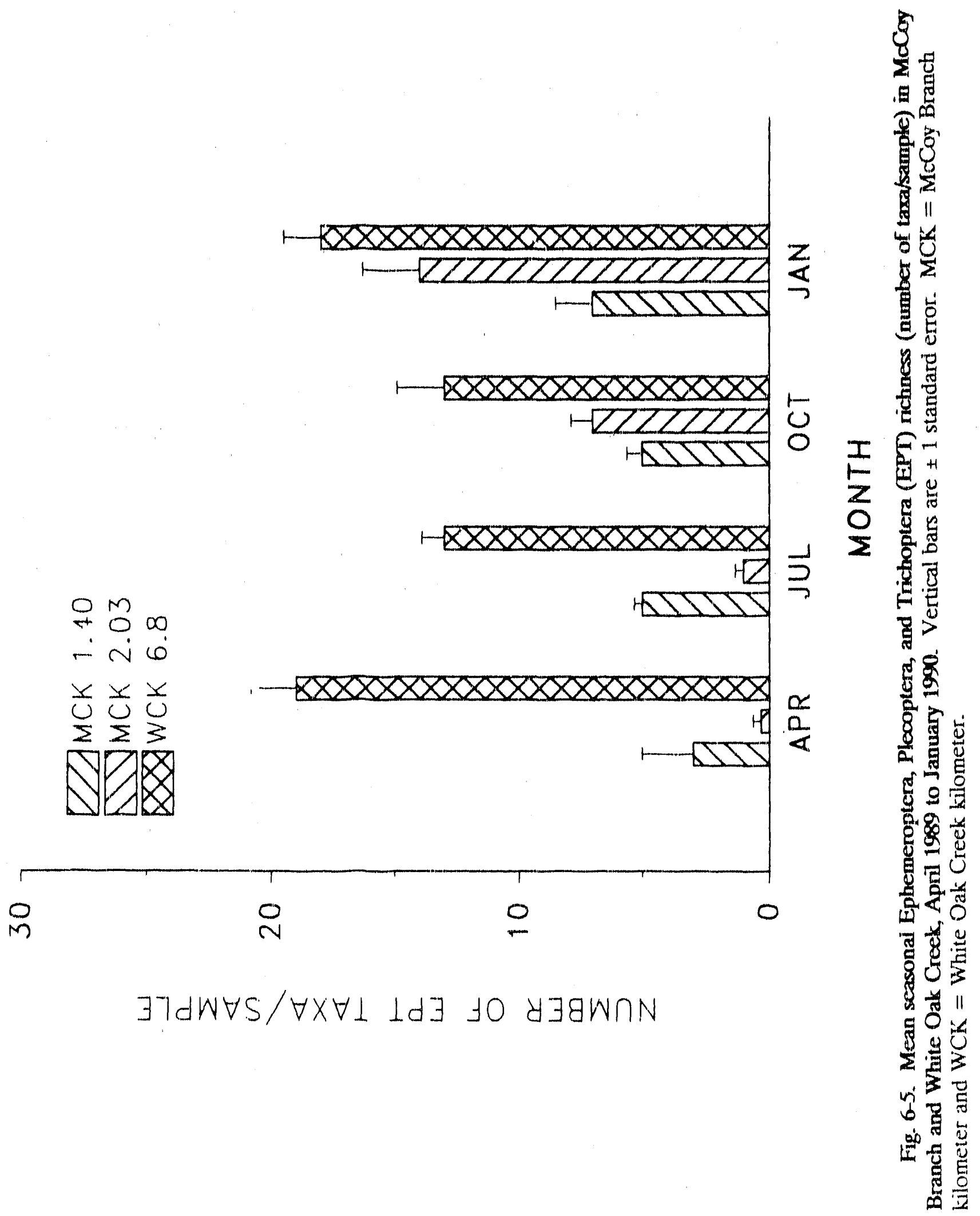




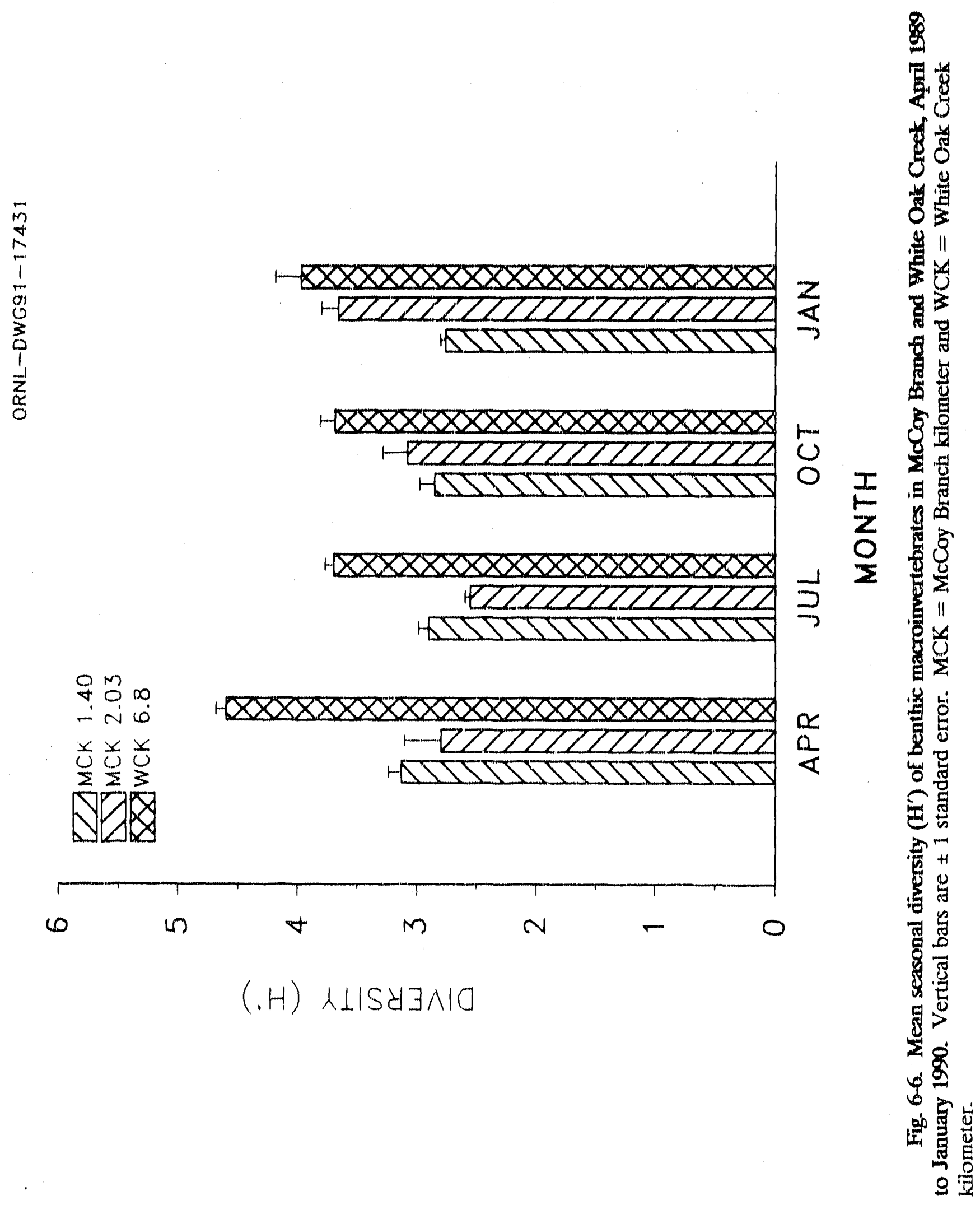


(o) MCK 1.4() Is implled by the signilicantly lower values for density and biomass. However, all parameters exhibited substantinl increases at MCK 2.(1)3 during the last Iwo sampling portods which suggests that recovery related lo improvements in water qually and/or physical habilal may have begun. These community changess may have beon the result of several metesures taken at the Y-12 steam plant since 1988 which have improved the water quality and redueed the quantity of eoal ash discharged to McCoy Branch (Soct, 2.2.1 and 2.2.2). Continued monitoring should determine If this trend at MCK 2.0.3 is the result of remedlal aetions or is a response to other unidentifled environmental f'aciors.

Relatively high conductivity measurements, $>5(x) \mu \mathrm{S} / \mathrm{cm}$, in McCoy Branch (J. G. Smith, Envifonmental Sciences Diviston, ORNL, personal communtication) in April 1989) suggest that the eoncerntration of dissolved solids may have been elevated. Lewer conductivity values in McCoy Branch after April may reflect a reduction in the use of conal and subseguently, the quantity of ash produced at the $Y-12$ steam plant starting during winter 1988 with a lurther scasonul reduction by April 1989) (Sect. 2.2.2). Dependings upon the flow, some llushing of deposiled ash may have occurred downstream of the ash pend such that the concentration in the stream has decreased with time. Further sampling will verify if " trend loward lower conductivity exists.

The compesition and structure of the benthic community in MeCoy Branch downstream of the ash pond appear to be responding to both physical and chemical stress. Suspended solids resulting from ash transport downstream ol the ash pond may be a major perturbation at MCK 2.(0). Within Rogers Quarty, scttling occurs so that the downstream load of suspended solids is redueed. Considerable deposits of coal ash were evident along and within the streambed at MCK 2.(1) at the beginning of this project, while the presence of eoal ash in lower MoCoy Branch was much less evident (Sect. 2.2.4; J. G. Smith, Environmental Sciences Division, ORNL, personal observation). Deposited solids can adversely affect organisms either directly by obstructing food collection and/or respiration, or indirectly by reducing food availability (Hynes 1970). Suspended solid deposition and sediment aecumulation have been shown to both decrease the density and biomass of benthic invertebrates by as much as 60\% (Gammon 1970) and reduce diversity by eliminating stress-sensitive taxa (Mackenthun 1973; Wiederholm 1984). The deposilion of fine-grained material also can provide a substrate lavorable for colonization by taxa colerant of these conditions such as chironomids (Wiederholm 1984). This may partially explain the prevalence of chironomids at MCK 2.03 compared to the other two sites.

In addition to deposited solids, some metals have historically oceurred in elevaled concentrations in McCoy Branch with higher levels above Rogers Quarry (Sect. 2.2.2, Tables A-3, A-4, A-5, and A-6, Yijg. 2-4 and 2.5). Of the metals measured, arsenic and selenium have the greater potential for impacts on acyatic life.

Studies by Elword in the $19^{\prime} /()$ s (R. R. Turner, Environmental Sciences Division, ORNL, personal communication) showed elevated levels of arsenic in aquatic insects in MeCoy Branch. Waller (quality samples taken between July 1986 and July 19\%() show that kevels of arsenic in MeCoy Branch exceeded the recommended maximum concentration (50 $\mu \mathrm{g} / \mathrm{L}$ ) fo: protection of' aqualic lif'c (EPA 1976) from July 1986 until approximalely 
July 1989. Levels of arsenic in McCoy Branch above $50 \mathrm{\mu g} / \mathrm{L}$ also occurred periodloally from January 1990) through approximately May 1990 (Fig. 2.4).

Levels of selentum in McCoy Branch consistently exceeded $10 \mu \mathrm{g} / \mathrm{L}$ from July 1986 through approximately January 1989. Maximum levels for protection of aquatic life are 26() $\mu \mathrm{g} / \mathrm{L}$ for acute exposure and $35 \mu \mathrm{g} / \mathrm{L}$ for chronic exposure; however, concentrations of $5 \mu \mathrm{g} / \mathrm{L}$, have been shown to adversely effect fish production (RFI 1987). From April 1989 to January 1990 levels of selenlum in McCoy Branch ranged from near zero to $10 \mu \mathrm{g} / \mathrm{L}$ with an average of approximately $5 \mu \mathrm{g} / \mathrm{L}$ (Fig. 2-5). It is possible that one or both of these metals could have an adverse effect on tho benthic community in McCoy Branch. The low density and richness of sensitive taxa, particularly maytlies, which are generally very sensitive to metal pollution (Wiederholm 1984), and the relatively high percent composition of chironomids indicate the benthic macroinvertebrate community in McCoy Branch may be rosponding to long-term exposure to elevated levels of these or other potential toxicants.

Finally, the magnitude of seasonal change of all parameters was most similar between MCK 1.40 and the reference site (WCK 6.8). This implies that environmental conditions were more stable at MCK 1.40 than at MCK 2.03, which may be a reflection of Rogers Quarry functioning as a setiling basin for both sediments and associated chemical contaminants. However, impoundments have been shown to alter chemical and physical conditions of streams, which in turn, alter the benthic invertebrate community (Ward and Stanford 1979). Thus, while reducing the Impacts associated with coal ash, the quarry itself alters natural conditions which lead to alterations in the benthic invertebrate community. Future changes in the benthic community at MCK 1.40 in response to remedial actions may be mediated by the presence of the quarry.

\subsection{CONCLUSIOINS}

The structure and composition of the benthic macroinvertebrate community in MeCoy Branch are indicative of moderate stress. Maximum impact within this stream occurs upstream of Rogers Quarry as was exemplified by the signilicantly higher density and biomass at MCK 1.40 compared to MCK 2.03. Some improvement in water quality was evident downstream of the quarry, as demonstrated by significant increases in caensity and biomass of the benthic community at MCK. 1.40. However, significantly lower values for taxonomic and EPT richness, and diversity at this site compared to the referenes site, indicate some impact. At MCK 2.03, substantial increases were observed in density, biomass, and taxonomic and EPT richness, particularly during the October and January sampling periods, suggesting that improvements in water quality may be occurring. The cause of the stress on the bentric macroinvertebrate community in McCoy Branch, at least upstream of Rogers Quarry, is most likely the result of several factors related to the long-term discharge of coal ash from the Y-12 steam plant. The benthos, particularly upstream of the quarry (MCK 2.03), appears to be responding to habitat alteration as the result of ash deposition within the stream channel and possibly to leaching of potential loxicants (e.g., arsenic: and selenium) from the ash. The benthic community at MCK 2.03 should recover as coal fines are removed from the streambed; however, recovery may be 
slowed by the less of supplemental llow in the upper reaches of' MeCoy Branch which may Increase the time regulred for natural cleansing of the stream.

Rogers Quatry acts as a setlling basin for coal ash transported downstream from the ash pond, thereby diminishing the impact of ash deposition on the benthic community downstream of the quarry. The benthic community at MCK 1.40 did not exhibit the temporal trends in increased density, biomass, or taxonomic and EPT richness shown by MCK 2.03, suggesting this community may not be experiencing similar changes in wator quality. Although Rogers Quarry appears to reduce the impacts associated with ash deposition, this impoundment likely alters the physical and chemical environment downstream, which in turn alters the invertebrate community. Finally, the direct discharge (1) ash to the quarry (initialed in May 19\%()) may cause the quarry to act as an immediate souree of toxicants through leaching of metals from the ash. This may impact the benthic community at MCK 1.40.

\subsection{FUTURE STUDIES}

The current sampling program for benthic macroinvertebrates will continuo. As for WCK 6.8 , the snail Elimia is a prominent member of the benthic macroinvertebrate communities of several streams that drain the south slope of Chestnut Ridge and the ORR (Smith 1991b). However, some relatively undisturbed streams in these same areas do not contain snails (Smith 1991b), and no historical data on the benthic macroinvertebrates ol' MoCoy Branch exists. Thus it is not known if Elimia have ever oceurred in this stream. Therefore, an additional reference stream without snails (Fifth Cicek, FFK 1.()) will be included in future analyses that will allow comparisons of MoCoy Branch to relerence streams with and without snails. This sampling program will provide a comprehensive characterization of the benthic community in McCoy Branch and an extensive data base that will allow documentation of the response of the benthic community as water quality changes occur as a result of remedial actions. The continued sampling progralin will provide further comparison of the benthic community at MCK 1.40 before and after direct discharge of bottom ash to Rogers Quarry and will document the resiponse of the benthic community at MCK 2.03 to the absence of ash discharge from the Y.12 Plant. 


\section{REFERENCES}

Bennett, G. W. 1970. Management of Lakes and Ponds. Van Nostrand Reinhold, New York.

Bjornberg, A., L. Hakanson, and K. Lundberg. 1988. A theory on the mechanisms regulating the bioavailability of mercury in natural waters. Environ. Pollut. 49:53-61.

Bogle, M. A., and R. R. Turner. 1989. Rogers Quarry water balance January 1, 1987 through June 30, 1988. Y/TS-506. Oak Ridge National Laboratory for Y-12 Plant, Oak Ridge, Tenn.

Bowen, H. J. M. 1979. Environmental Chemistry of the Elements. Academic Press, London.

Burris, J. A., M. S. Bamford, and A. J. Stewart. 1990. Behavioral responses of marked snails as indicators of water quality. Environ. Tox. Chem. 9:69-76.

Carle, F. L., and M. R. Strub. 1978. A new method for estimating population size from removal data. Biometrics 34:621-630.

Craig, P. M., and B. A. Tschantz. 1986. Preliminary seepage residual study by water balance method for Rogers Quarry. Y/SUB/86-1819/2. Y-12 Plant, Oak Ridge, Tenn.

Crutchfield, P. J. 1966. Positive rheotaxis in Goniobasis proxima. Nautilus 79:80-86.

Cirta. M. L. A., and R. W. Furness. 1988. Uptake and elimination of inorganic mercury and selenium by minnows, Phoxinus phoxinus. Aquat. Toxicol., 13:205-216.

Dycus, D. L. 1989. Results of fish tissue screening studies from sites in the Tennessee and Cumberland Rivers in 1987. TVA/WR/AB - 89/5. T'ennessee Valley Authority, Chattanooga, Tenn.

Dycus, D. L., and G. D. Hickman. 1986. Concentrations of PCBs, DDTr, and metals in fish from Tellico Reservoir. TVA/ONRED/AWR-87/25. Tennessee Valley Authority, Knoxville, Tenn.

Elliott, J. M. 1977. Some methods for the statistical analysis of samples of benthic invertebrates. Freshwater Biological Association, Ambleside, England. Sci. Pub. No. 25.

Elwood, J. W. 1984. Mercury contamination in Poplar Creck and the Clinch River. ORNL/TM-8893. Oak Ridge National Laboratory, Oak Ridge, Tenn.

ERDA (Energy Research and Development Administration). 1975. Preliminary draft environmental analysis report. Oak Ridge Operations, Volume VI. Oak Ridge, Tenn.

Everhart, W. H., A. W. Eipper, and D. W. Youngs. 1975. Principles of Fishery Science. Cornell University Press, Ithaca, New York.

Gammon, J. R. 1970. The effect of inorganic sediment on stream biota. Water Pollution Control Research Series, 18050DWC12/70, Water Quality Office, U.S. Environmental Protection Agency, Washington, D.C.

Greeson, P. E., T. A. Ehlke, G. A. Irwin, B. W. Lium, and K. V. Slack. 1977. Methods for collection and analysis of aquatic biological and microbiological samples. Book 5 , Chapter 4A, pp. 1-332. In U.S. Geological Survey, Techniques of Water-Resources Investigations of the United States Geological Survey. U.S. Government Printing Office, Washington, D.C.

Hand, J., and M. Friedman. 1990. Mercury, largemouth bass, and water quality: A preliminary report. Florida Department of Environmental Regulation, Tallahassee, Fla. 
Hile, R. 1936. Age and growth of the cisco, Leucichthys artedi (LeSeur), in the lakes of the northeastern highlands, Wisconsin. U.S. Bur. Fish. Bull. 48:211-317.

Hodson, P. V. 1990. Indicators of ecosystem heaith at the species level and the example of selenium effects on fish. Environ. Monitor. Assess. 15:241-254.

Hoffman, F. O., B. G. Blaylock, C. C. Travis, K. L. Daniels, E. L. Etnier, K. E. Cowser, and C. W. Weber. 1984. Preliminary screening of contaminants in sediments. ORNL/TM-9370. Oak Ridge National Laboratory, Oak Ridge, Tenn.

Houp, K. H. 1970. Population dynamics of Pleurocera acuta in a central Kentucky limestone stream. Am. Midl. Nat. 83:81-88.

Hynes, H. B. N. 1970. The Ecology of Running Water. University of Toronto Press, 'Toronto.

IRIS. 1989. Integrated Risk Information System (data base). U.S. Environmental Protection Agency, Office of Research and Development, Washington, D.C.

Jones, R. A., and R. Mishu. 1986. Geotechnical and hydrologic evaluation of Y-12 Plant coal ash dam. Y.SUB/86-479701-1, prepared by Geotek Engineering Co. for the Oak Ridge Y'-12 Plant. Oak Ridge, Tenn.

Karr, J. R. 1981. Assessment of biotic integrity using fish communities. Fisheries. $6: 21-27$.

Karr, J. R. 1987. Biological monitoring and assessment: A conceptual framework. Environ. Manage. 11:249-256.

Karr, J. R., K. D. Fausch, P. L. Angermeicr, P. R. Yant, and I. J. Schlosser. 1986. Assessing biological integrity in running waters: A method and its rationale. Illinois Natural History Survey Special Publication: 5. Urbana, Ill.

Ketelle, R. H., and D. D. Huff, 1984. Site characterization of the West Chestnut Ridge Site. ORNL/TM-9229. Oak Ridge National Laboratory, Oak Ridge, Tenn.

Kszos, L. A., and A. J. Stewart. 1991. Effort-allocation analysis of the 7-d lathead minnow (Pimephales promelas) and Ceriodaphnia dubia toxicity tests. Environmental Toxicology Chemistry (in press).

Kiszos, L. A., A. J. Stewart, L. F. Wicker, and G. M. Logsdon. 1989. Environmental Sciences Division Toxicology Laboratory standard operating procedures. ORNL/TM11194, Oak Ridge National Laboratory, Oak Ridge, Tenn.

Lenat, D. R. 1984. Agriculture and stream water quality: A biological evaluation of erosion control practices. Environ. Manage, 8:333-344.

Len:1, D. R. 1988. Water quality assessment of streams using a qualitative collection method for benthic macroinvertebrates. J. North Am. Benthol. Soc. 7:222-233.

Leonard, P. M. and D. J. Orth. 1986. Application and testing of an Index of Biotic Integrity in small, conlwater streams. Trans. Amer. Fish. Soc. 115:401-414.

Loar, J. M. (cd.). 1985. Application of habitat evaluation models in southern Appalachian trout streams. ORNL/TM-9323. Oak Ridge National Laboratory, Oak Ridge, Tenn.

Lowe, T. P., T. W. May, W. G. Brumbaugh, and D. A. Kane. 1985. National centaminant hiomonitoring program: Concentrations of seven elements in freshwater fis 1 , 1978-1981. Arch. Environ. Contam. Toxicol. 14:36.3-388.

Mackenthun, K. M. !973. Toward a Cleaner Aquatic Environment. U.S. Government Printing Oflice, Washinglon, D.C.

Martin Marietta Energy Systems, Inc. 1985. Environmental monitoring report, United States Department of Energy, Oak Ridge facilities, calendar year 1984. ORNL-6209. Oak Ridge National Laboratory, Oak Ridge, Tenn. 
Martin Marietta Energy Systems, Inc. 1986. Environmental surveillance of the Oak Ridge Reservation and surrounding environs during 1985. ORNL-6721. Oak Ridge National Laboratory, Oak Ridge, Tenn.

McCauley, L. L. 1986. Proposed ground-water monitoring plans for the Kerr Hollow and the Rogers Quarries. Y/SUB/85-(00206C/4R1. Prepared by Geraughty and Miiler, Inc. for the Oak Ridge Y-12 Plant, April 1986. Oak Ridge, Tenn.

Murphy, J. L. 1988. RCRA facility investigation plan filled coal ash pond (D-112) Oak Ridge Y-12 Plant Oak Ridge, Tennessee. Y/TS-411. Oak Ridge Y-12 Plant, Oak Ridge, Tenn.

Murphy, J. L., and J. M. Loar. 1988. Expanded RCRA facility investigation plan McCoy Branch Oak Ridge Y-12 Plant Oak Ridge, Tennessee. Y/TS-488. Oak Ridge Y-12 Plant, Oak Ridge, Tenn.

Pielou, E. C. 1977. Mathematical Ecology. John Wiley, New York.

Platts, W. S., Megahan, W. F., and Minshall, G. W. 1983. Methods for evaluating stream, riparian, and biotic conditions. U.S. Forest Service General Technical Report INT-138. Intermountain Forest and Range Experimental Station, Ogdon, Utah.

Pulliam, P. J. 1985a. Water quality data for 34 sites, April and June 1984, near the Y-12 Plant, the Oak Ridge Reservation, Tennessee. USGS 85-165. Nashville, Tenn.

Pulliam, P. J. 1985b. Water quality data for 35 sites, September 1984, near the Y-12 Plant, the Oak Ridge Reservation, Tennessec. USGS 85-553. Nashville, Tenn.

Railsback, S. F., B. D. Holcomb, and M. G. Ryon. 1989. A computer program for estimating fish population sizes and annual production rates. ORNL/TM-11061. Oak Ridge National Laboratory, Oak Ridge Tenn.

RFI. 1987. RCRA Facility Investigation (RFI) guidance. Vol. III. Air and surface water releases. EPA 530/SW-87-001. Waste Management Division, Office of Solid Waste, U.S. Environmental Protection Agency, Washington, D.C.

Rogers, J. G., K. L. Daniels, S. T. Goodpasture, C. W. Kimbrough, and E. W. Whitfield. 1988. Environmental surveillanee of the U.S. Department of Energy Oak Ridge Reservation and surrounding environs during 1987, Vol. 1: Narrative, summary and conclusions. ES/ESH-4/V1. Environmental and Safety Activities, Martin Marictta Energy Systems, Inc., Oak Ridge, Tenn.

Rogers, J. G., K. L. Daniels, S. T. Goodpasture, C. W. Kimbrough, and N. L. Prince. 1989. Oak Ridge Reservation En ironmental Report for 1988, Vol. 1: Narrative, Summary and conclusions. ES/ESH-8/V1. Environmental and Safety Activities, Martin Marietla Energy Systems, Inc., Oak Ridge, Tenn.

Ross, M. J. and G. R. Ultsch. 1980. Temperature and substate influence on habitat selection in two pleurocerid snails (Goniobasis). Am. Midl. Nat. 103:209-217.

Rudd, J. W. M., M. A. Turner, B. E. Townsend, A. Swick, and A. Furutani. 1980. Dynamics of selenium in mercury-contaminated experimental freshwater ecosystems. Can. J. Fish. Aquat. Sci. 37:848-857.

Ryon, M. G., and J. M. Loar. 1988. A checklist of fishes on the Department of Energy Oak Ridge Reservation. J. Tenn. Acad. Sci. 58(4):97-102.

SAS Institute, Inc. 1985a. SAS User's Guide: Basics, Version 5 edition. Sas Institute, Inc., Cary, N.C.

SAS Institute, Inc, 1985b. SAS User's Guide: Statistics, Version 5 edition. SAS Irstitute, Inc., Cary, N.C. 
Smith, J. G. 1991 a. Benthic macroinvertebrates. In J. M. Loar, (ed.), First annual report on the Y. 12 Plant Biological Monitoring and Abatement Program.

ORNL/TM-10861. Oak Ridge National Laboratory, Oak Ridge, Tenn. (in press).

Smith, J. G. 1991b. Benthic macroinvertebrates. In G. R. Southworth, (ed.), Ecological effects of contaminants and remedial actions in Bear Creek. ORNL/TM-10370. Oak Ridge National Laboratory, Oak Ridge, Tenn. (in press).

Sorensen, E. M. B, and T. L. Bauer. 1983. Hematological dyscrasia in teleosts chronically exposed to selenium-laden effluent. Arch. Environ. Contam. Toxicol. 12:135-141.

Sorensen, E. M. B., P. M. Cumbie, T. L. Bauer, J. S. Bell, and C. W. Harlan. 1984. Histopathological, hematological, condition factor, and organ weight changes associated with selenium accumulation in fish from Belews Lake, North Carolina. Arch. Environ. Contam. Toxicol. 13:153-162.

Southworth, G. R. 1991. Accumulation of contaminants by biota in East Fork Poplar Creek. In J. M. Loar, (ed.), First annual report on the Y-12 Plant Biological Monitoring and Abatement Program. ORNL/TM-10861. Oak Ridge National Laboratory, Oak Ridge, Tenn. (in press).

Steel, R. G. D., and J. H. Torrie, 1980. Principles and procedures of statistics, 2nd Ed. McGraw-Hill, New York.

Stewart, A. J. $19 \mathcal{M})$. Monitoring of conservative water quality factors in ORNL streams may be operationally advantageous. In Environmental Sciences Division Annual Progress Report for Period Ending Septernber 30, 1989. ORNL-6602. Oak Ridge National Laboratory, Oak Ridge, Tenn.

Stewart, A. J., L. A. Kszos, B. C. Harvey, L. F. Wicker, G. J. Haynes, and R. D. Bailey. 19(9). Ambient toxicity dynamics: Assessments using Ceriodaphnia dubia and fathead minnow (Pimephales promelas) larvae in short-term te:ts. Environ. Tox. Chem. 9:367-379.

TDPH (Tennessee Department of Public Health). 1978. Water quality management plan for the Clinch River Basin. Division of Water Quality Control, Tennessee Department of Public Health, Nashville, Tenn.

TVA (Tennessee Valley Authority). 1985. Instream contaminant study, Task 4: Fish sampling and analysis. Report to U.S. Department of Energy, Oak Ridge Operations Office. Tennessee Valley Authority, Office of Natural Resourees and Economic Development, Knoxville, Tenn.

Turner, M. A., and J. W. M. Rudd. 1983. The English-Wabigoon River system: III. Selenium in lake enclosures: Its geochemistry, bioaccumulation, and ability to reduce mercury bioaccumulation. Carı. J. Fish. Aquat. Sci. 40:2228-2240.

Turner, M. A., and A. L. Swick. 1983. The English-Wabigoon River system: IV. Interaction between mercury and selenium accumulated from waterborne and dietary sources by northern pike (Escx lucius). Can. J. Fish. Aquat. Sci. 40:2241-2250.

Turner, R. R., M. A. Bogle, M. A. Kane, and T. M. Mercer. 1986. Characterization of Y-12 Plant coal ash discharge to McCoy Branch. Y/TS-177. Oak Ridge Y-12 Plant, Oak Ridge, Tenn.

EPA (U. S. Environmental Protection Agency). 1976. Quality Criteria for Water. EPA 440/9-76-(123, U. S. Environmental Protection Agency, Washington, D.C.

EPA (U.S. Environmental Protection Agency). 1986. Test methods for evaluating solid waste. SW 846, 3d ed. Office of Solid Waste and Emergency Response, Washington, D.C. 
EPA (U.S. Environmental Protection Agency). 1990. Region IV toxic substances spreadsheet. U. S. EPA, Region IV, Atlanta, Georgia. July 1990. Unpublished mimeo, 8 pp.

Ward, J. V. and J. A. Stanford (eds.). 1979. The Ecology of Regulated Streams. Plenum Press, New York.

Weber, C. I. (ed.). 1973. Biological field and laboratory methods for measuring the quality of surface waters and effluents. EPA 670/4-73-001. National Environmental Research Center, U.S. Environmental Protection Agency, Cincinnati.

Weber, C. I., W. H. Peltier, T. J. Norberg-King, W. B. Horning, F. A. Kessler, J. R. Mendedick, T. W. Neiheisel, P. A. Lewis, D. J. Klemm, Q. H. Pickering, E. L. Robinson, J. M. Lazorchak, L. J. Wymer, and R. W. Freyberg. 1989. Shortterm methods for estimating the chronic toxicity of effluents and receiving waters to freshwater organisms. EPA/600/4-89/001, Environmental Monitoring Systems Laboratory, Cincinnati.

Wiederholm, T. 1984. Responses of aquatic insects to environmental pollution. pp. 508-557. In V. H. Resh and D. M. Rosenberg, (eds.), The ecology of aquatic insects. Praeger Publishers, New York. 
APPENDIX A

WATER QUALITY DATA FOR MCCOY BRANCH WATERSHED FOR 1974-1990 
Table A-1. Water quality data collected in 1984 for two sites in the McCoy Branch watersheat

\begin{tabular}{|c|c|c|c|}
\hline \multirow[b]{2}{*}{ Parameler } & \multicolumn{2}{|c|}{$\begin{array}{c}\text { April \& June } \\
1984\end{array}$} & \multirow{2}{*}{$\begin{array}{c}\begin{array}{c}\text { Sept, } \\
1984\end{array} \\
\begin{array}{c}\text { Downstrean } \\
\text { site }\end{array}\end{array}$} \\
\hline & $\begin{array}{l}\text { Upstream } \\
\text { sitc }\end{array}$ & $\begin{array}{c}\text { Downstrcam } \\
\text { sitce }\end{array}$ & \\
\hline Alkalinity, lab (mg/L as $\mathrm{CaCO}_{3}$ ) & 143 & 111 & $\mathrm{NA}$ \\
\hline Alkalinity, field (mg/L as $\left.\mathrm{CaCO}_{3}\right)$ & NA & NA & 78 \\
\hline Arsenic, total ( $\mu \mathrm{g} / \mathrm{L}$ as As) & NA & $\mathrm{NA}$ & 110 \\
\hline Barium, total recoverable ( $\mu \mathrm{g} / \mathrm{L}$ as $\mathrm{Ba})$ & 100 & 100 & $1(x)$ \\
\hline Beryllium, total recoverable ( $\mu \mathrm{g} / \mathrm{L}$ as $\mathrm{Be})$ & $<10$ & $<10$ & $<10$ \\
\hline Cadmium, total recoverable $(\mu \mathrm{g} / \mathrm{L}$ as $\mathrm{Cd})$ & $<1$ & $<1$ & $<1$ \\
\hline Calcium, dissolved ( $\mathrm{mg} / \mathrm{L}$ as $\mathrm{Ca}$ ) & 41 & 40 & 32 \\
\hline Carbon, organic total (mg/L as C) & 0.40 & 0.70 & NA \\
\hline Carbon, organic dissolved ( $\mathrm{mg} / \mathrm{L}$ as $\mathrm{C}$ ) & NA & NA & 2.7 \\
\hline Chloride, dissolved ( $\mathrm{mg} / \mathrm{L}$ as $\mathrm{Cl}$ ) & 2.7 & 3.8 & 3.6 \\
\hline Chromium, Total recoverable ( $\mu \mathrm{g} / \mathrm{L}$ as $\mathrm{Cr}$ ) & 3 & 7 & $<1$ \\
\hline Cobalt, total recoverable $(\mu \mathrm{g} / \mathrm{L}$ as $\mathrm{C}(0)$ & NA & NA & $<1$ \\
\hline Cobalt, total recoverable $(\mu \mathrm{g} / \mathrm{L})$ & 10) & 1 & NA \\
\hline Copper, total recoverable ( $\mu \mathrm{g} / \mathrm{L}$ as $\mathrm{Cu})$ & 1 & 4 & 1 \\
\hline Cyanide, total (mg/L as CN) & $<0.01$ & $<0,01$ & $<(), 01$ \\
\hline Gross Beta, dissolved ( $\mathrm{pCi} / \mathrm{L}$ as $\mathrm{Cs}-137$ ) & NA & $<2.6$ & 2.6 \\
\hline Gross Alpha, susp. tolal ( $\mu \mathrm{g} / \mathrm{L}$ as U-NÁT) & NA & 2.4 & 0,8 \\
\hline Gross Beta, susp. total (pCl/L as Cs-137) & NA & 1.9 & 0.7 \\
\hline Gross Beta, dissolved (pCi/L as $\mathrm{Sr} / Y-9())$ & NA & $<2.2$ & 2.2 \\
\hline Gross Alpha, dissolved ( $\mu \mathrm{g} / \mathrm{L}$ as U.NAT) & NA & $<4.6$ & $<4.3$ \\
\hline Gross Beta, susp. total (pCi/L as $\mathrm{Sr} / \mathrm{Y}-90)$ & NA & 1.7 & 0.6 \\
\hline Instantancous discharge (L/s) & 7.7 & 87.8 & $50) .9$ \\
\hline Iron, total recowerable ( $\mu \mathrm{g} / \mathrm{L}$ as $\mathrm{Fe}$ ) & 1600 & 290 & 390 \\
\hline Lead, total recoverable ( $\mu \mathrm{g} / \mathrm{L}$ as $\mathrm{Pb})$ & 5 & 5 & 3 \\
\hline Lithium, total recoverable ( $\mu \mathrm{g} / \mathrm{L}$ as Li) & 9() & 90 & 70 \\
\hline Magnesium, dissolved ( $\mathrm{mg} / \mathrm{L}$ as $\mathrm{Mg}$ ) & 13 & 9.7 & 7 \\
\hline Manganesc, total recoverable ( $\mu \mathrm{g} / \mathrm{L}$ as $\mathrm{Mn})$ & $100)$ & 50 & 2() \\
\hline Mercury, total recoverable ( $\mu \mathrm{g} / \mathrm{L}$ as $\mathrm{Hg}$ ) & $<0,1$ & $<0.1$ & $<0,1$ \\
\hline Molybdenum, total recoverable ( $\mu \mathrm{g} / \mathrm{L}$ as Mo) & 11 & 32 & 35 \\
\hline Nickel, total recoverable $(\mu \mathrm{g} / \mathrm{L}$ as $\mathrm{Ni})$ & NA & NA & 1 \\
\hline Nitrogen, $\mathrm{NO}_{2}+\mathrm{NO}_{3}$ dissolved (mg/L as $\mathrm{N}$ ) & $01(0)$ & $<() .1$ & 3.2 \\
\hline Nitrogen, ammonia + organic tolal (mg/L as $\mathrm{N}$ ) & NA & NA & 0.50 \\
\hline Nitrogen, ammonia dissolved ( $\mathrm{mg} / \mathrm{L}$ as $\mathrm{N})$ & NA & NA & $<0,01$ \\
\hline Oxygen, dissolved (mg/L) & NA & 12.6 & 9.5 \\
\hline Phosphorus, dissolved (mg/L as P) & 0.0 .30 & 0.080 & $<0,01$ \\
\hline Phosphorus, ortho-dissolved (mg/L as P) & NA & NA & 0.112 \\
\hline Phosphorus, total (mg/L as P) & NA & NA & 0.04 \\
\hline Polassium, dissolved ( $\mathrm{mg} / \mathrm{L}$ as $\mathrm{Na}$ ) & 4.5 & 3.1 & 3.2 \\
\hline Sclenium, lotal $(\mu \mathrm{g} / \mathrm{L}$, ats Sc) & NA & NA & 8 \\
\hline Sodium, dissolved ( $\mathrm{mg} / \mathrm{L}$ a as $\mathrm{Na}$ ) & 2.5 & 3.3 & 3.3 \\
\hline Solids residue at 18()$^{\circ} \mathrm{C}$, dissolved $(\mathrm{mg} / \mathrm{L})$ & 231 & 204 & 166 \\
\hline
\end{tabular}


Table A-1 (Continued)

\begin{tabular}{|c|c|c|c|}
\hline \multirow[b]{2}{*}{ Parameter } & \multicolumn{2}{|c|}{$\begin{array}{c}\text { April \& June } \\
1984\end{array}$} & \multirow{2}{*}{$\begin{array}{c}\begin{array}{c}\text { Sept. } \\
1984\end{array} \\
\begin{array}{c}\text { Downstream } \\
\text { ste }\end{array}\end{array}$} \\
\hline & $\begin{array}{l}\text { Upstream } \\
\text { site }\end{array}$ & $\begin{array}{c}\text { Downstream } \\
\text { site }\end{array}$ & \\
\hline Speciflc conductance $(\mu \mathrm{S} / \mathrm{cm})$ & 360 & 324 & 250 \\
\hline Strontium, total recoverable $(\mu \mathrm{g} / \mathrm{L}$ as $\mathrm{Sr})$ & 770 & 230 & 250) \\
\hline Sulfate, dissolved (mg/L as $\mathrm{SO}_{4}$ ) & 34 & 48 & 50 \\
\hline Temperature $\left({ }^{\circ} \mathrm{C}\right)$ & 12.5 & 12.0 & 19.0 \\
\hline Uranium, natural dissolved ( $\mu \mathrm{g} / \mathrm{L}$ as $\mathrm{U})$ & 1.0 & 2.5 & 2.2 \\
\hline Vanadium, dissolved ( $\mu \mathrm{g} / \mathrm{L}$ as $\mathrm{V})$ & $<1$ & 30 & 23 \\
\hline Zinc, total recoverable ( $\mu \mathrm{g} / \mathrm{L}$ as $\mathrm{Zn}$ ) & 20 & 20) & 10 \\
\hline
\end{tabular}

The upstream site is located between the ash pond and Rogers Quarry. The downstream site is located below Rogers Quarry. Data for some sites were not avallable (NA), Sources: P. J. Pullium (1985a and 1985b). 


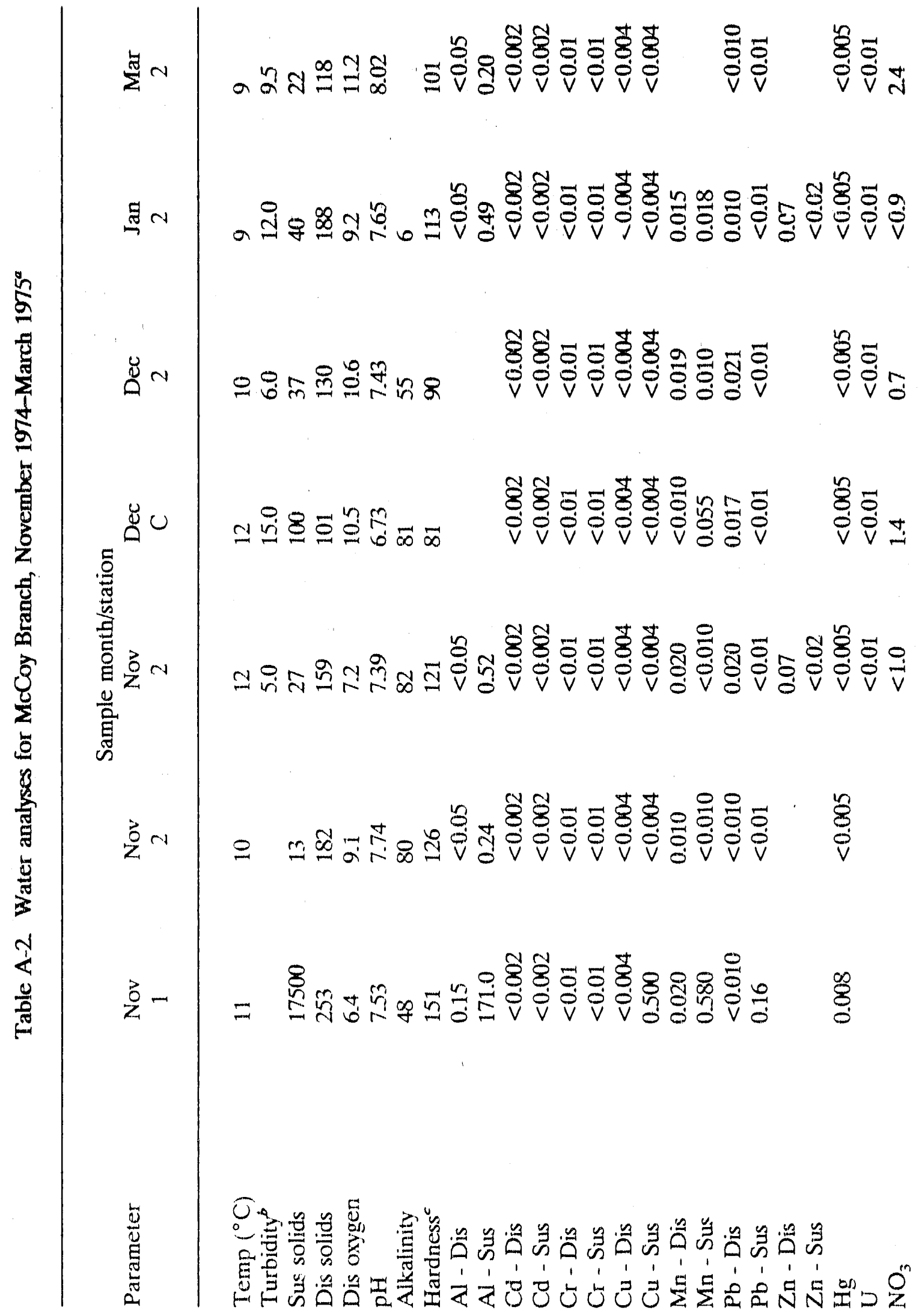




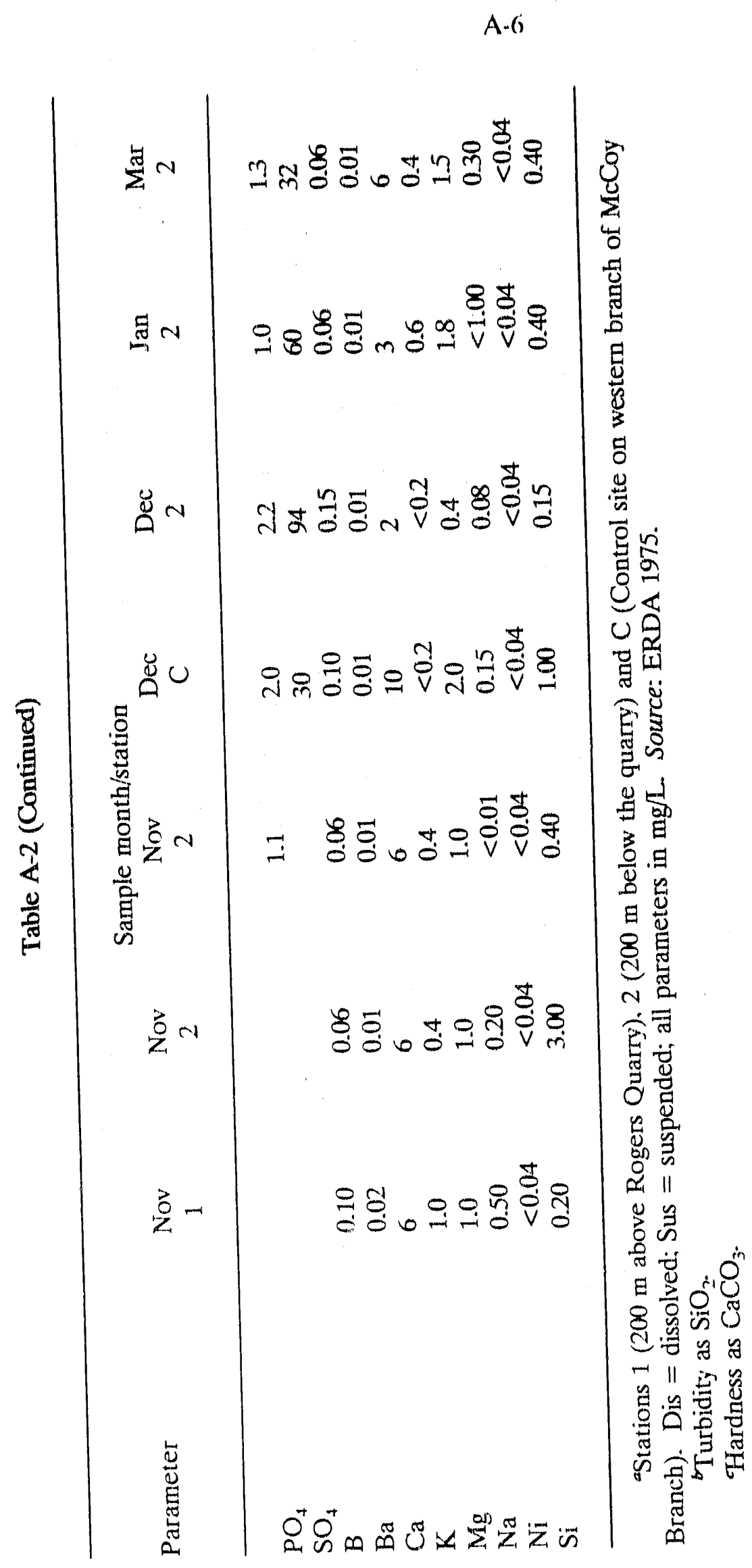


A. 7

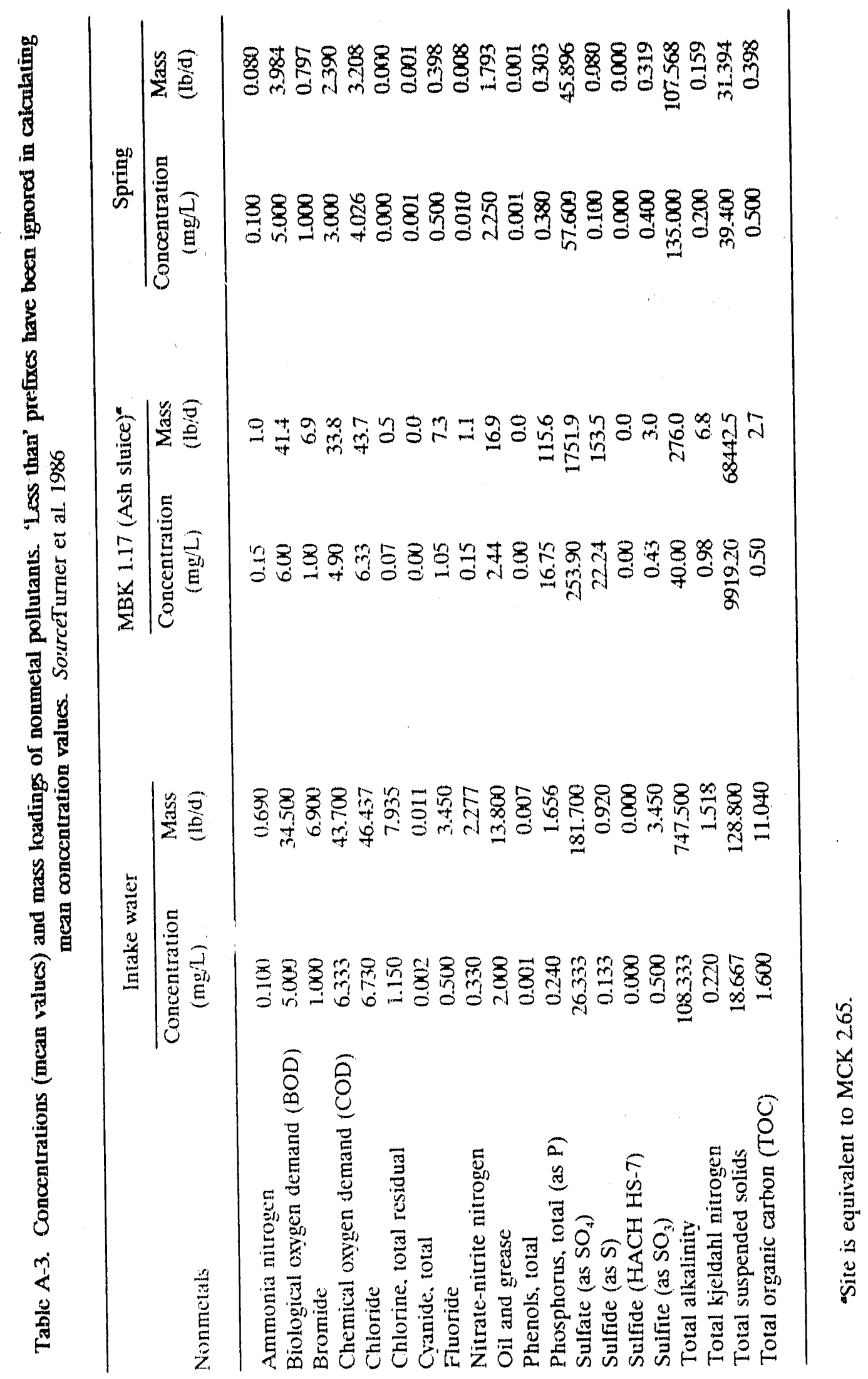


A. 8

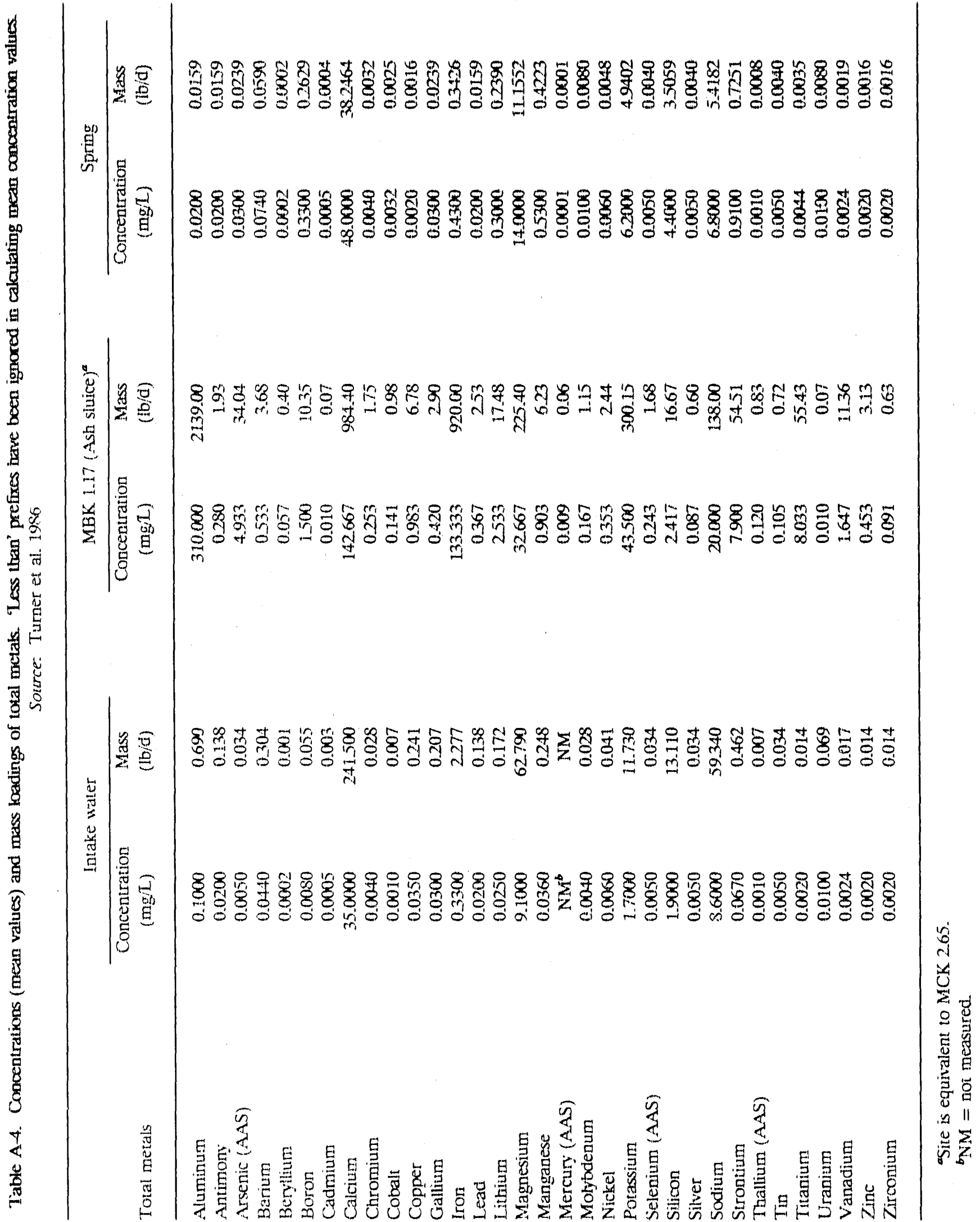


A.9

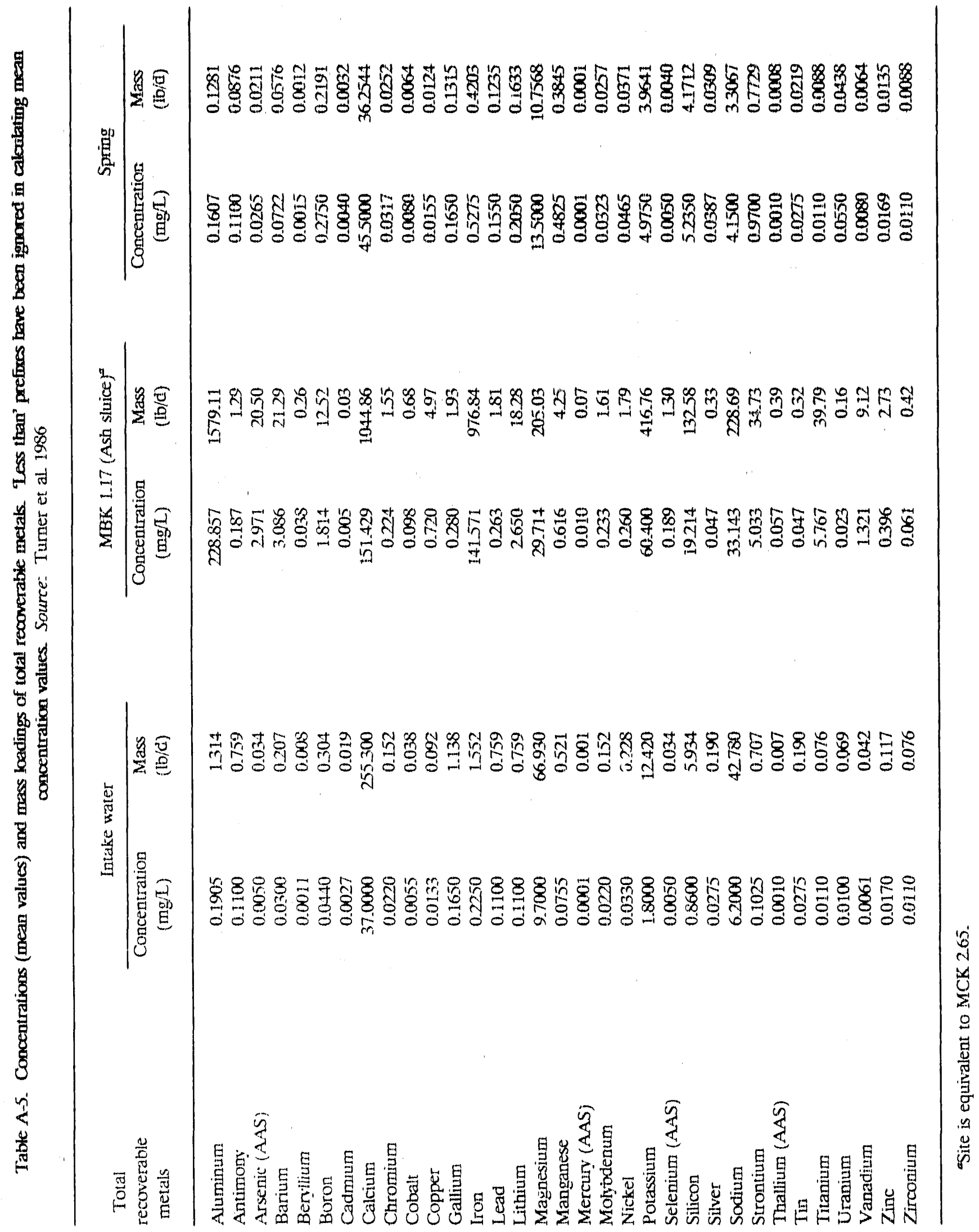


A. 10

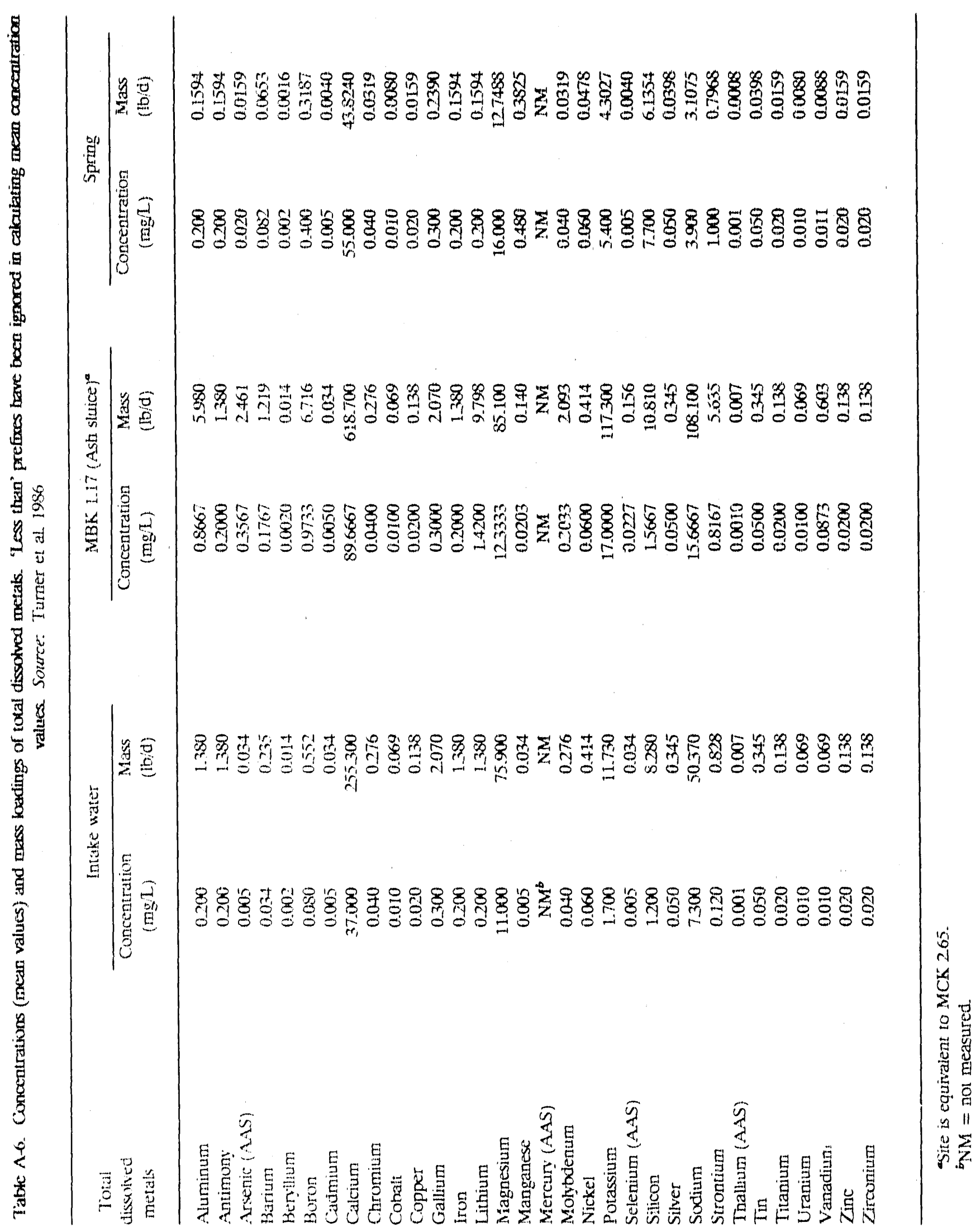


Table A-7. Sample types and locations for surface water, groundwater, coal ash, and floodplain sediment samples of McCoy Branch, July 30-October 17, 1990. Source: CH2M Hill, personal communication

Dry Weather Surface Water Sampling, July 30, 1990

\begin{tabular}{ccc} 
Sample No. & $\begin{array}{c}\text { Approximate stream } \\
\text { location }\end{array}$ & Sample type \\
\hline S3 & MCK 2.62 & Environmental - Aqueous \\
S4 & MCK 2.52 & Environmental - Aqueous \\
S5 & MCK 1.92 & Environmental - Aqueous \\
S6 & MCK 1.92 & Duplicate of S5 \\
\hline
\end{tabular}

Wet Weather Water Sampling, October 8, 1990

Sample No. Approximate stream $\quad$ Sample type location

\begin{tabular}{ccc}
\hline WW-S1 & MCK 1.92 & Environmental - Aqueous \\
WW-S3 & MCK 2.62 & Environmental - Aqueous \\
WW-S4 & MCK 2.52 & Environmental - Aqueous \\
WW-S6 & $\ldots$ & Field Blank - Aqueous \\
WW-S7 & $\ldots$ & Equipment Blank - Aqueous \\
\hline
\end{tabular}

Groundwater sampling

\begin{tabular}{|c|c|c|c|}
\hline Sample No. & Location & $\begin{array}{l}\text { Approximate stream } \\
\text { location }^{b}\end{array}$ & Sample date \\
\hline $50(0)$ & GW-321 & MCK 2.62 & 16 OCT 90 \\
\hline 5001 & GW-672 & MCK 2.61 & 15 ОСТ 90 \\
\hline $50(12$ & GW-67.3 & MCK 2.40 & 16 OCT 90 \\
\hline 50$) 3$ & GW-674 & MCK 2.38 & 16 OCT 90 \\
\hline $5(0) 4$ & GW-676 & MCK 2.14 & 17 ОСТ 90) \\
\hline 50015 & GW-676 & MCK 2.14 & 17 OCT 90 \\
\hline $5(k) 6$ & GW-676 & MCK 2.14 & 17 OCT 90 \\
\hline 50017 & GW-672 & MCK 2.61 & 15 ОСТ 90 \\
\hline
\end{tabular}


Table A-7 (Continued)

\begin{tabular}{|c|c|c|c|c|}
\hline \multicolumn{5}{|c|}{ Ash/Soil Sampling } \\
\hline \multirow{2}{*}{ Sample No. } & \multirow{2}{*}{$\frac{\text { Location }}{A 1}$} & \multirow{2}{*}{$\begin{array}{c}\begin{array}{c}\text { Approximate } \\
\text { stream location }^{b}\end{array} \\
\text { MCK } 2.38\end{array}$} & \multicolumn{2}{|c|}{ Sample type ${ }^{c}$} \\
\hline & & & Environmental Soil & $\left(0.6^{\prime \prime} \mathrm{BI}\right)$ \\
\hline $\mathrm{A} 1-\mathrm{S} 2$ & A1 & MCK 2.38 & Environmental Soil & $\left(6-12^{\prime \prime} \mathrm{BL}\right)$ \\
\hline A2-A & $\mathrm{A} 2$ & MCK 2.62 & Environmental Soil & (ASH) \\
\hline A2-S1 & $\mathrm{A} 2$ & MCK 2.62 & Environmental Soil & $\left(0-6^{\prime \prime} \mathrm{BA}\right)$ \\
\hline A.3-A & $A 3$ & MCK 2.52 & Environmental Soil & $(\mathrm{ASH})$ \\
\hline A3-S1 & A.3 & MCK 2.52 & Environmental Soil & $\left(0-6^{\prime \prime} \mathrm{BA}\right)$ \\
\hline A.3-S2 & A.3 & MCK 2.52 & Environmental Soil & $\left(6-12^{\prime \prime} \mathrm{BA}\right)$ \\
\hline A4-A & A4 & MCK 2.40 & Environmental Soil & (ASH) \\
\hline A4-S1 & A4 & MCK 2.40 & Environmental Soil & $\left(0-6^{\prime \prime} \mathrm{BA}\right)$ \\
\hline $\mathrm{A} 4-\mathrm{S} 2$ & A4 & MCK 2.40 & Environmental Soil & $\left(6-12^{\prime \prime} \mathrm{BA}\right)$ \\
\hline A.5-A & A5 & MCK 2.10 & Environmental Soil & (ASH) \\
\hline A $5-S 1$ & A5 & MCK 2.10 & Environmental Soil & $\left(0-6^{\prime \prime} \mathrm{BA}\right)$ \\
\hline A5-S2 & A5 & MCK 2.10 & Environmental Soil & $\left(6-12^{\prime \prime} \mathrm{BA}\right)$ \\
\hline A6-A & A6 & MCK 1.97 & Environmental Soil & $(\mathrm{ASH})$ \\
\hline $\mathrm{A} 6-\mathrm{S} 1$ & A6 & MCK 1.97 & Environmental Soil & $\left(0 \cdot 6^{\prime \prime} \mathrm{BA}\right)$ \\
\hline $\mathrm{A} 6-\mathrm{S} 2$ & A6 & MCK 1.97 & Environmental Soil & $\left(6-12^{\prime \prime} \mathrm{BA}\right)$ \\
\hline A7-A & A.3 & MCK 2.52 & Environmental Soil & $(\mathrm{ASH})$ \\
\hline A7-S1 & A.3 & MCK 2.52 & Environmental Soil & $\left(0-6^{\prime \prime} \mathrm{BA}\right)$ \\
\hline A 7-S2 & A.3 & MCK 2.52 & Environmental Soil & $\left(6-12^{\prime \prime} \mathrm{BA}\right)$ \\
\hline
\end{tabular}

${ }^{a}$ Wet weather sample taken after a $4.5-\mathrm{cm}$ rain event, measured at the gage at Rogers Quarry.

${ }^{b}$ Location in terms of stream kilometers; actual sample sites are located in floodplain and may be several meters east or west from stream kilometer.

${ }^{c} \mathrm{BA}=$ Below ash; $\mathrm{BL}=$ Below land. 
Table A-8. Concentrations of volatile organic compounds measured in surface water samples of McCoy Branch, July 30, 1990.

Source: CH2M Hill, personal communication

\begin{tabular}{|c|c|c|c|c|}
\hline \multirow{2}{*}{$\begin{array}{l}\text { Compound } \\
(\mu \mathrm{g} / \mathrm{L})\end{array}$} & \multicolumn{4}{|c|}{ Site } \\
\hline & MCK 2.62 & MCK 2.52 & MCK 1.92 & MCK $1.92^{a}$ \\
\hline 1,1-Dichloroethane & 5 & 5 & 5 & 5 \\
\hline 1,1-Dichloroethene & 5 & 5 & 5 & 5 \\
\hline 1,1,1-Trichloroethane & 5 & 5 & 5 & 5 \\
\hline 1,1,2-Trichloroethane & $5 \mathrm{UJ}^{b}$ & $5 \mathrm{UJ}$ & $5 \mathrm{UJ}$ & $5 \mathrm{UJ}$ \\
\hline $1,1,2,2$-Tetrachloroethane & 5 & 5 & 5 & 5 \\
\hline 1,2-Dichloroethane & 5 & 5 & 5 & 5 \\
\hline 1,2-Dichloroethane-d $4^{c}$ & 49.5 & 48.5 & 49.1 & 49.2 \\
\hline 1,2-Dichloroethene (Total) & 5 & 5 & 5 & 5 \\
\hline 1,2-Dichloropropane & 5 & 5 & 5 & 5 \\
\hline 2-Butanone & 10 & 10 & 10 & 10 \\
\hline 2-Hexanone & 10 & 10 & 10 & 10 \\
\hline 4-Methyl-2-Pentanone & 10 & 10 & 10 & 10 \\
\hline Acetone & $7 \mathrm{UJ}$ & $6 \mathrm{UJ}$ & $19 \mathrm{UJ}$ & $5 \mathrm{UJ}$ \\
\hline Benzene & 5 & 5 & 5 & 5 \\
\hline Bromodichloromethane & 5 & 5 & 5 & 5 \\
\hline Bromofluorobenzene ${ }^{c}$ & 53.9 & 57.4 & 53.6 & 52.5 \\
\hline Bromoform & $5 \mathrm{UJ}$ & $5 \mathrm{UJ}$ & $5 \mathrm{UJ}$ & $5 \mathrm{UJ}$ \\
\hline Bromomethane & 10 & 10 & 10 & 10 \\
\hline Carbon disulfide & 5 & 5 & 5 & 5 \\
\hline Carbon tetrachloride & 5 & 5 & 5 & 5 \\
\hline Chlorobenzene & 5 & 5 & 5 & 5 \\
\hline Chloroethane & 10 & 10 & 10 & 10 \\
\hline Chloroform & 5 & 5 & 5 & 5 \\
\hline Chloromethane & 10 & 10 & 10 & 10 \\
\hline cis-1,3-Dichloropropene & $5 \mathrm{UJ}$ & $5 \mathrm{UJ}$ & $5 \mathrm{UJ}$ & $5 \mathrm{UJ}$ \\
\hline Dibromochloromethane & $5 \mathrm{UJ}$ & $5 \mathrm{UJ}$ & $5 \mathrm{UJ}$ & $5 \mathrm{UJ}$ \\
\hline Ethylbenzene & 5 & 5 & 5 & 5 \\
\hline Methylene chloride & 5 & 5 & 5 & 5 \\
\hline Styrene & 5 & 5 & 5 & 5 \\
\hline Tetrachloroethene & 5 & 5 & 5 & 5 \\
\hline Toluene & 5 & 5 & 5 & 5 \\
\hline Toluene-d $8^{c}$ & 54.4 & 54.9 & 53.8 & 53.5 \\
\hline Total xylenes & 5 & 5 & 5 & 5 \\
\hline trans-1,3-Dichloropropene & $5 \mathrm{UJ}$ & $5 \mathrm{UJ}$ & $5 \mathrm{UJ}$ & $5 \mathrm{UJ}$ \\
\hline
\end{tabular}




\section{A- 14}

Table A-8 (Continued)

\begin{tabular}{lcccc}
\hline \multirow{1}{*}{$\begin{array}{c}\text { Compound } \\
(\mu \mathrm{g} / \mathrm{L})\end{array}$} & MCK 2.62 & MCK 2.52 & MCK 1.92 & MCK $1.92^{a}$ \\
\cline { 2 - 5 } & 5 & 5 & 5 & 5 \\
\hline $\begin{array}{l}\text { Trichloroethene } \\
\text { Vinyl chloride }\end{array}$ & 10 & 10 & 10 & 10 \\
Vinyl acetate & $2 \mathrm{UJ}$ & $2 \mathrm{UJ}$ & $2 \mathrm{UJ}$ & $2 \mathrm{UJ}$ \\
& & & & \\
\hline
\end{tabular}

"Duplicate samples.

${ }^{b} \mathrm{~J}=$ estimated value; $\mathrm{U}=$ undetected-below method detection level.

Tentatively identified compounds. 
Table A-9. Concentrations of semivolatile organic compounds measured in surface water samples from McCoy Branch, July 30, 1990.

Source: CH2M Hill, personal communication

\begin{tabular}{|c|c|c|c|c|}
\hline $\begin{array}{c}\text { Compound } \\
(\mu \mathrm{g} / \mathrm{L})\end{array}$ & MCK 2.62 & MCK 2.52 & MCK 1.92 & $\operatorname{MCK} 1.92^{\circ}$ \\
\hline 1,2-Dichlorobenzene & 10 & $10 \mathrm{UJ}^{b}$ & $10 \mathrm{UJ}$ & $10 \mathrm{UJ}$ \\
\hline 1,2,4-Trichlorobenzene & $10 \mathrm{U}$ & $10 \mathrm{UJ}$ & $10 \mathrm{UJ}$ & $10 \mathrm{UJ}$ \\
\hline 1,3-Dichlorobenzene & $10 \mathrm{U}$ & $10 \mathrm{UJ}$ & $10 \mathrm{UJ}$ & $10 \mathrm{UJ}$ \\
\hline 1,4-Dichlrobenzene & 10 & $10 \mathrm{UJ}$ & $10 \mathrm{UJ}$ & $10 \mathrm{UJ}$ \\
\hline 2-Chloronaphthalene & $10 \mathrm{U}$ & $10 \mathrm{UJ}$ & $10 \mathrm{UJ}$ & $10 \mathrm{UJ}$ \\
\hline 2-Chlorophenol & $\mathrm{R}^{b}$ & $\mathbf{R}$ & $10 \mathrm{UJ}$ & $10 \mathrm{UJ}$ \\
\hline 2-Methylnaphthalene & $10 \mathrm{U}$ & $10 \mathrm{UJ}$ & $10 \mathrm{UJ}$ & $10 \mathrm{UJ}$ \\
\hline 2-Methylphenol & $\mathrm{R}$ & $\mathrm{R}$ & $10 \mathrm{UJ}$ & $10 \mathrm{UJ}$ \\
\hline 2-Nitroaniline & 50 & $50 \mathrm{UJ}$ & $50 \mathrm{UJ}$ & $50 \mathrm{UJ}$ \\
\hline 2-Nitrophenol & $\mathrm{R}$ & $\mathbf{R}$ & $10 \mathrm{UJ}$ & $10 \mathrm{UJ}$ \\
\hline 2,4-Dichlorophenol & $\mathrm{R}$ & $\mathrm{R}$ & $10 \mathrm{UJ}$ & $10 \mathrm{UJ}$ \\
\hline 2,4-Dimethylphenol & $\mathrm{R}$ & $\mathrm{R}$ & $10 \mathrm{UJ}$ & $10 \mathrm{UJ}$ \\
\hline 2,4-Dinitrophenol & $\mathrm{R}$ & $\mathrm{R}$ & $50 \mathrm{UJ}$ & $50 \mathrm{UJ}$ \\
\hline 2,4-Dinitrotoluene & 10 & $10 \mathrm{UJ}$ & $10 \mathrm{UJ}$ & $10 \mathrm{UJ}$ \\
\hline 2,4,5-Trichlorophenol & $\mathrm{R}$ & $\mathrm{R}$ & $50 \mathrm{UJ}$ & $50 \mathrm{UJ}$ \\
\hline 2,4,6-Trichlorophenol & $\mathrm{R}$ & $\mathrm{R}$ & $10 \mathrm{UJ}$ & $10 \mathrm{UJ}$ \\
\hline 2,6-Dinitrotoluene & $10 \mathrm{U}$ & $10 \mathrm{UJ}$ & $10 \mathrm{UJ}$ & $10 \mathrm{UJ}$ \\
\hline 3-Nitroaniline & $50 \mathrm{U}$ & $50 \mathrm{UJ}$ & $50 \mathrm{UJ}$ & $50 \mathrm{UJ}$ \\
\hline 3,3'-Dichlorobenzidine & 20 & $20 \mathrm{UJ}$ & $20 \mathrm{UJ}$ & $20 \mathrm{UJ}$ \\
\hline 4-Bromophenyl-phenylether & 10 & $10 \mathrm{UJ}$ & $10 \mathrm{UJ}$ & $10 \mathrm{UJ}$ \\
\hline 4-Chloro-3-methylphenol & $\mathrm{R}$ & $\mathrm{R}$ & $10 \mathrm{UJ}$ & $10 \mathrm{UJ}$ \\
\hline 4-Chloroaniline & 10 & $10 \mathrm{UJ}$ & $10 \mathrm{UJ}$ & $10 \mathrm{UJ}$ \\
\hline 4-Chlorophenyl-phenylether & 10 & $10 \mathrm{UJ}$ & $10 \mathrm{UJ}$ & $10 \mathrm{UJ}$ \\
\hline 4-Methylphenol & $\mathrm{R}$ & $\mathrm{R}$ & $10 \mathrm{UJ}$ & $10 \mathrm{UJ}$ \\
\hline 4-Nitroaniline & 50 & $50 \mathrm{UJ}$ & $50 \mathrm{UJ}$ & $50 \mathrm{UJ}$ \\
\hline 4-Nitrophenol & $\mathrm{R}$ & $\mathrm{R}$ & $50 \mathrm{UJ}$ & $50 \mathrm{UJ}$ \\
\hline 4,6-Dinitro-2-methylphenol & $\mathrm{R}$ & $\mathrm{R}$ & $50 \mathrm{UJ}$ & $50 \mathrm{UJ}$ \\
\hline Acenaphthene & $10 U$ & $10 \mathrm{UJ}$ & $10 \mathrm{UJ}$ & $10 \mathrm{UJ}$ \\
\hline Acenaphthylene & 10 & $10 \mathrm{UJ}$ & $10 \mathrm{UJ}$ & $10 \mathrm{UJ}$ \\
\hline Anthracene & 10 & $10 \mathrm{UJ}$ & $10 \mathrm{UJ}$ & $10 \mathrm{UJ}$ \\
\hline Benzo(a)pyrene & 10 & $10 \mathrm{UJ}$ & $10 \mathrm{UJ}$ & $10 \mathrm{UJ}$ \\
\hline Benzo(a,h)anthracenc & 10 & $10 \mathrm{UJ}$ & $10 \mathrm{UJ}$ & $10 \mathrm{UJ}$ \\
\hline Benzo(b)fluoranthene & 10 & $10 \mathrm{UJ}$ & $10 \mathrm{UJ}$ & $10 \mathrm{UJ}$ \\
\hline Benzos $(g, h, i)$ perylene & 10 & $10 \mathrm{UJ}$ & $10 \mathrm{UJ}$ & 10 UJ \\
\hline Benzo(k)fluoranthene & 10 & $10 \mathrm{UJ}$ & $10 \mathrm{UJ}$ & $10 \mathrm{UJ}$ \\
\hline
\end{tabular}


Table A-9 (Continued)

\begin{tabular}{|c|c|c|c|c|}
\hline $\begin{array}{c}\text { Compound } \\
(\mu \mathrm{g} / \mathrm{L})\end{array}$ & MCK 2.62 & MCK 2.52 & MCK 1.92 & $\operatorname{MCK} 1.92^{a}$ \\
\hline Benzoic Acid & $\mathrm{R}$ & $\mathrm{R}$ & $50 \mathrm{UJ}$ & $50 \mathrm{UJ}$ \\
\hline Benzyl Alcohol & 10 & $10 \mathrm{UJ}$ & $10 \mathrm{UJ}$ & $10 \mathrm{UJ}$ \\
\hline bis(2-Chloroethoxy)methane & $10 U$ & $10 \mathrm{UJ}$ & $10 \mathrm{UJ}$ & $10 \mathrm{UJ}$ \\
\hline bis(2-Chloroethyl) Ether & $10 \mathrm{U}$ & $10 \mathrm{UJ}$ & $10 \mathrm{UJ}$ & $10 \mathrm{UJ}$ \\
\hline bis(2-chloroisopropyl)ether & $10 \mathrm{UJ}$ & $10 \mathrm{UJ}$ & $10 \mathrm{UJ}$ & $10 \mathrm{UJ}$ \\
\hline bis(2-Ethylhexyl)phthalate & $10 \mathrm{UJ}$ & $10 \mathrm{UJ}$ & $10 \mathrm{UJ}$ & $10 \mathrm{UJ}$ \\
\hline Butylbenzylphthalate & $10 \mathrm{UJ}$ & $10 \mathrm{UJ}$ & $10 \mathrm{UJ}$ & $10 \mathrm{UJ}$ \\
\hline Chrysene & $10 \mathrm{UJ}$ & $10 \mathrm{UJ}$ & $10 \mathrm{UJ}$ & $10 \mathrm{UJ}$ \\
\hline Di-n-butylphthalate & $10 \mathrm{UJ}$ & $10 \mathrm{UJ}$ & $10 \mathrm{UJ}$ & $10 \mathrm{UJ}$ \\
\hline Di-n-octylphthalate & $10 \mathrm{UJ}$ & $27 \mathrm{~J}$ & $10 \mathrm{UJ}$ & $10 \mathrm{UJ}$ \\
\hline Dibenz(a,h)anthracene & $10 \mathrm{UJ}$ & $10 \mathrm{UJ}$ & $10 \mathrm{UJ}$ & $10 \mathrm{UJ}$ \\
\hline Dibenzofuran & $10 \mathrm{UJ}$ & $10 \mathrm{UJ}$ & $10 \mathrm{UJ}$ & $10 \mathrm{UJ}$ \\
\hline Diethylphthalate & $10 \mathrm{UJ}$ & $10 \mathrm{UJ}$ & $10 \mathrm{UJ}$ & $10 \mathrm{UJ}$ \\
\hline Dimethylphthalate & $10 \mathrm{UJ}$ & $10 \mathrm{UJ}$ & $10 \mathrm{UJ}$ & $10 \mathrm{UJ}$ \\
\hline Fluoranthene & $10 \mathrm{UJ}$ & $10 \mathrm{UJ}$ & $10 \mathrm{UJ}$ & $10 \mathrm{UJ}$ \\
\hline Fluorene & $10 \mathrm{UJ}$ & $10 \mathrm{UJ}$ & $10 \mathrm{UJ}$ & $10 \mathrm{UJ}$ \\
\hline Hexachlorethane & $10 \mathrm{UJ}$ & $10 \mathrm{UJ}$ & $10 \mathrm{UJ}$ & $10 \mathrm{UJ}$ \\
\hline Hexachlorobenzene & $10 \mathrm{UJ}$ & $10 \mathrm{UJ}$ & $10 \mathrm{UJ}$ & $10 \mathrm{UJ}$ \\
\hline Hexachlorocyclobutadiene & $10 \mathrm{UJ}$ & $10 \mathrm{UJ}$ & $10 \mathrm{UJ}$ & $10 \mathrm{UJ}$ \\
\hline Hexachlorocyclopentadiene & $10 \mathrm{UJ}$ & $10 \mathrm{UJ}$ & $10 \mathrm{UJ}$ & $10 \mathrm{UJ}$ \\
\hline Hexane, 3-methoxy & & $4.87 \mathrm{UJ}$ & & \\
\hline Indeno(1,2,3-cd)pyrene & $10 \mathrm{UJ}$ & $10 \mathrm{UJ}$ & $10 \mathrm{UJ}$ & $10 \mathrm{UJ}$ \\
\hline Isophorone & $10 \mathrm{UJ}$ & $10 \mathrm{UJ}$ & $10 \mathrm{UJ}$ & $10 \mathrm{UJ}$ \\
\hline N-Nitrose-Di-n-propylamine & $10 \mathrm{UJ}$ & $10 \mathrm{UJ}$ & $10 \mathrm{UJ}$ & $10 \mathrm{UJ}$ \\
\hline $\mathrm{N}$-Nitrosodiphenylamine (1) & $10 \mathrm{UJ}$ & $10 \mathrm{UJ}$ & $10 \mathrm{UJ}$ & $10 \mathrm{UJ}$ \\
\hline Napthalene & $10 \mathrm{UJ}$ & 10. $\mathrm{UJ}$ & $10 \mathrm{UJ}$ & $10 \mathrm{UJ}$ \\
\hline Nitrobenzene & $10 \mathrm{UJ}$ & $10 \mathrm{UJ}$ & 10 UJ & $10 \mathrm{UJ}$ \\
\hline Fentachlorophenol & $\mathrm{R}$ & $\mathrm{R}$ & $50 \mathrm{UJ}$ & $50 \mathrm{UJ}$ \\
\hline Phenanthrene & 10) UJ & $10 \mathrm{UJ}$ & $10 \mathrm{UJ}$ & $10 \mathrm{UJ}$ \\
\hline Phenol & $\mathrm{R}$ & $\mathrm{R}$ & $10 \mathrm{UJ}$ & $10 \mathrm{UJ}$ \\
\hline Pyrenc & $10 \mathrm{UJ}$ & $10 \mathrm{UJ}$ & $10 \mathrm{UJ}$ & $10 \mathrm{UJ}$ \\
\hline Unknown & $4.92 \cup J$ & $4.79 \mathrm{UJ}$ & $4.91 \mathrm{UJ}$ & $4.87 \mathrm{UJ}$ \\
\hline Unknown & $7.06 \mathrm{UJ}$ & & & $9.33 \mathrm{UJ}$ \\
\hline
\end{tabular}

${ }^{a}$ Duplicate sample laken at MCK 1.92.

${ }^{b} \mathrm{~J}=$ estimated value; $\mathrm{R}=$ rejected value; $\mathrm{U}=$ undetected-below method detection kevel. 
A-17

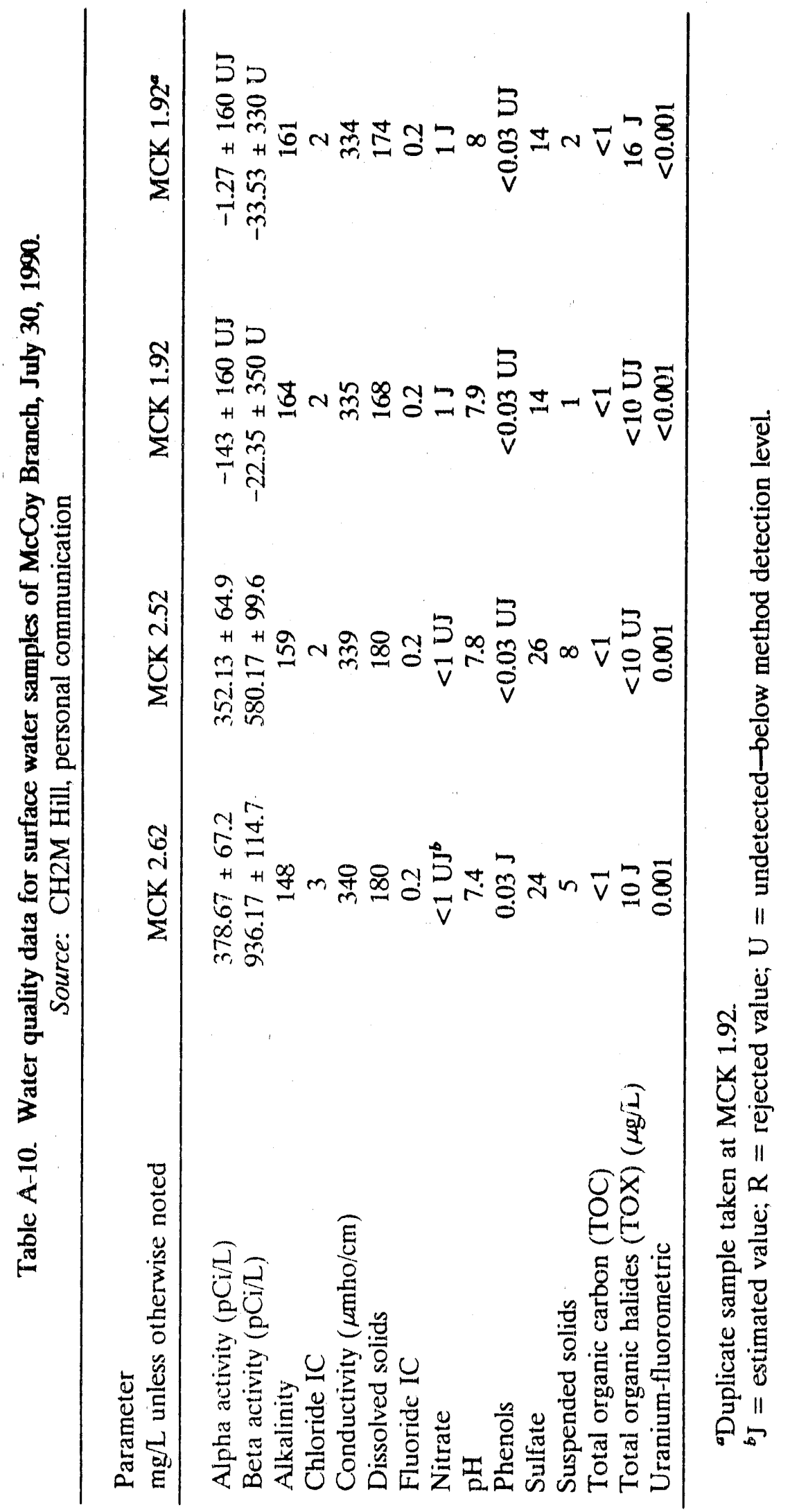


Table A-11. Concentrations of elements measured in surface water samples of McCoy Branchir July 30,1990 . Sites labeled $-F$ are filtered samples. Source: CH2M Hill, personal communication

\begin{tabular}{|c|c|c|c|c|c|c|c|c|}
\hline $\begin{array}{c}\text { Element } \\
(\mu \mathrm{g} / \mathrm{L})\end{array}$ & $\begin{array}{r}\text { MCK } \\
2.62 \\
\end{array}$ & $\begin{array}{c}\text { MCK } \\
2.62-\mathrm{F} \\
\end{array}$ & $\begin{array}{r}\text { MCK } \\
2.52 \\
\end{array}$ & $\begin{array}{c}\text { MCK } \\
2.52-\mathrm{F}\end{array}$ & $\begin{array}{r}\text { MCK } \\
1.92\end{array}$ & $\begin{array}{c}M C K \\
1.92-\mathrm{F}\end{array}$ & $\begin{array}{l}\text { MCK } \\
1.92^{\circ}\end{array}$ & $\begin{array}{c}\text { MCK } \\
1,92-1^{0}\end{array}$ \\
\hline Aluminum & $129 \mathrm{~J}^{6}$ & 32.0 & $39.4 \mathrm{~J}$ & 38.2 & $39.4 \mathrm{~J}$ & 38.2 & $48.7 \mathrm{~J}$ & 50.5 \\
\hline Antimony & 50.0 & 50.0 & 50.0 & 50.0 & 50.0 & 50.0 & 50.0 & 50.0 \\
\hline Arsenic & 84.8 & 32.0 & 21.0 & 19.9 & 2.1 & 2.1 & 2.1 & 2.1 \\
\hline Barium & 60.6 & 65.6 & 49.6 & 48.9 & 78.5 & 78.2 & 70.2 & 77.9 \\
\hline Beryllium & 0.30 & 0.30 & 0.30 & 0.30 & 0.30 & 0.30 & 0.30 & 0.30 \\
\hline Cadmium & 3.0 & 3.0 & 3.0 & 3.0 & 3.0 & 3.0 & 3.0 & 3.0 \\
\hline Calcium & 4.3900 & 43200 & 45500 & 44200 & 44700 & 45300 & 32300 & 44800 \\
\hline Chromium & 10.0 & 10.0 & 10.0 & 10.0 & 10.0 & 10.0 & 10.0 & 10.0 \\
\hline Cobalt & 5.0 & 5.0 & 5.0 & 5.0 & 5.0 & 5.0 & 5.0 & 5.0 \\
\hline Copper & 4.0 & 7.1 & 4.0 & 4.5 & 4.1 & 4.9 & 4.0 & 4.0 \\
\hline Iron & 1360 & 316 & 5.8 & $14.7 \mathrm{~J}$ & 4.0 & $18.3 \mathrm{~J}$ & 4.0 & $15.1 \mathrm{~J}$ \\
\hline Lead & $0.80 \mathrm{UJ}$ & $0.80 \mathrm{UJ}$ & $0.80 \mathrm{UJ}$ & 0.80 & $0.80 \mathrm{UJ}$ & 0.80 & $\begin{array}{c}0.80 \\
\text { UJ }\end{array}$ & $0.80 \mathrm{~J}$ \\
\hline Magnesium & 1.3600 & 13200 & 13.500 & 12900 & 14700 & 14400 & 13600 & 14200 \\
\hline Manganese & 513 & 1000 & 16.8 & 29.6 & 1.0 & 28.1 & 1.0 & 28.8 \\
\hline Mercury & 1.0 & 1.0 & 1.0 & 1.0 & 1.0 & 1.0 & 1.0 & 1.0 \\
\hline Nickel & 10.0 & 10.0 & 10.0 & 10.0 & 10.0 & 10.0 & 10.0 & 10.0 \\
\hline Niobium & $7.0 \mathrm{UJ}$ & $7.0 \mathrm{UJ}$ & $7.0 \mathrm{UJ}$ & 8.5 & 7.9 & $7.0 \mathrm{UJ}$ & $7.0 \mathrm{UJ}$ & $7.0 \mathrm{UJ}$ \\
\hline Phosphorous & $200 \mathrm{UJ}$ & $200 \mathrm{UJ}$ & $200 \mathrm{UJ}$ & $200 \mathrm{UJJ}$ & $200 \mathrm{UJ}$ & $200 \mathrm{UJ}$ & $z(x) \cup J$ & $200 \mathrm{UJ}$ \\
\hline Potassium & 4940 & 4430 & 4530 & 44.50 & 2070 & 21.30 & 2040 & 2000 \\
\hline Selenium & $2.0 \mathrm{UJ}$ & $2.0 \mathrm{UJ}$ & $2.0 \mathrm{UJ}$ & 2.0 & $2.0 \mathrm{UJ}$ & 2.0 & $20 \mathrm{UJ}$ & 2.0 \\
\hline Silver & 6.0 & 6.0 & 6.0 & 6.0 & 6.0 & 6.0 & 6.0 & 6.0 \\
\hline Sodium & 2780 & 2740 & 2920 & 3160 & 18.50 & 1730 & 1600 & 1720 \\
\hline Vanadium & 5.0 & 5.0 & 5.0 & 5.0 & 5.0 & 5.0 & 5.0 & 5.13 \\
\hline Kinc & $3.3 \mathrm{~J}$ & $6.0 \mathrm{~J}$ & $2.9 \mathrm{~J}$ & $3.1 \mathrm{~J}$ & $3.6 \mathrm{~J}$ & $5.0 \mathrm{~J}$ & $2.1 \mathrm{~J}$ & $5.6 \mathrm{~J}$ \\
\hline
\end{tabular}

DD Dplicale sample liken at MCK 1.92.

${ }^{b} \mathrm{~J}=$ estimated value: $\mathrm{R}=$ rejected value; $\mathrm{U}=$ undetected-below method detection level. 


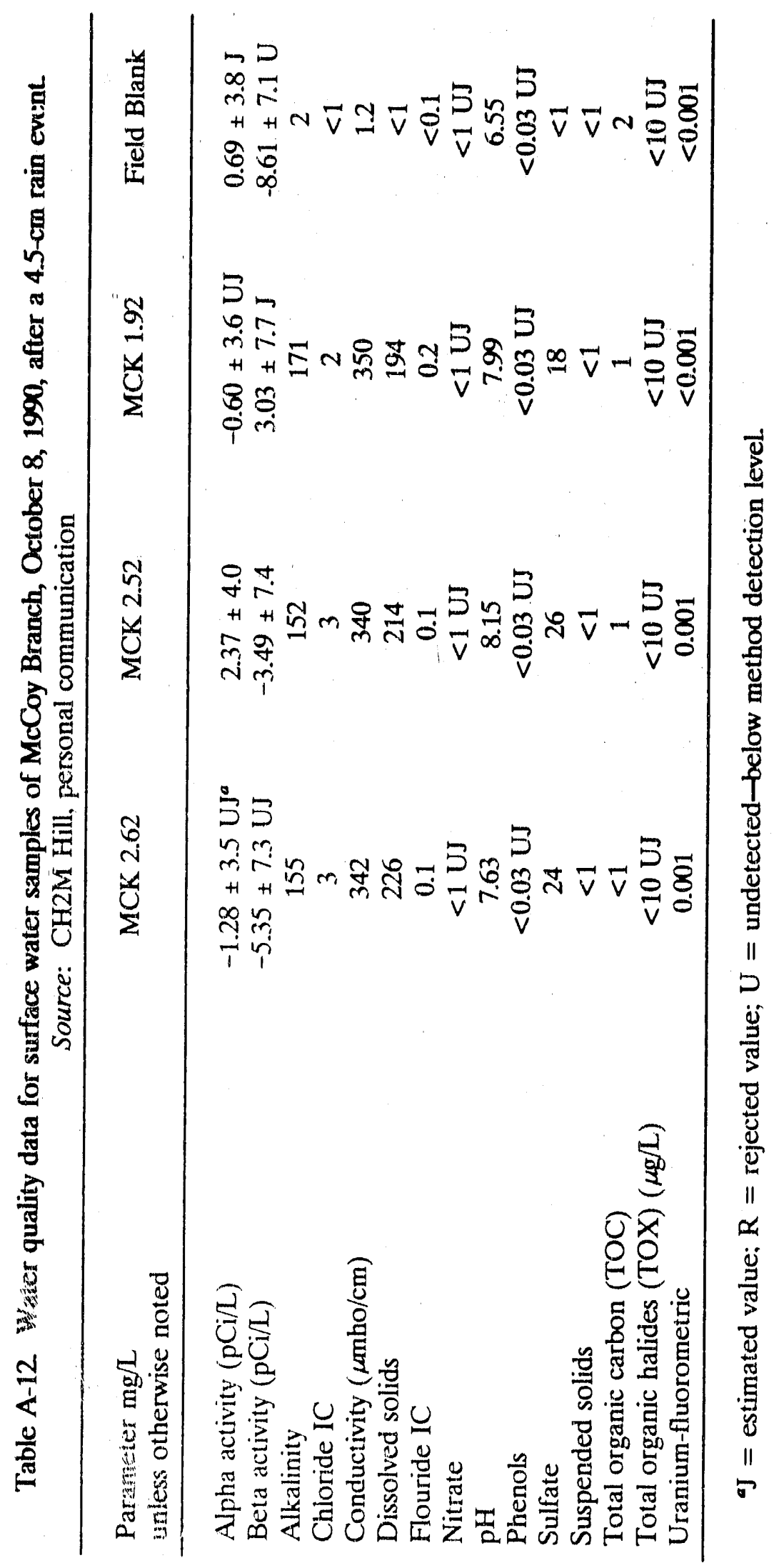




\section{A-20}

table A-13. Concentrations of elements measured in surface water samples of Mcroy Branch, October 8, 1990, after a $4.5-\mathrm{cm}$ rain event. Source: $\mathrm{CH} 2 \mathrm{M}$ Hill, personal communication

\begin{tabular}{|c|c|c|c|c|c|c|c|c|}
\hline $\begin{array}{l}\text { Element } \\
(\mu \mathrm{g} / \mathrm{L})\end{array}$ & $\begin{array}{r}\mathrm{MCK} \\
2.62\end{array}$ & $\begin{array}{l}\text { MCK } \\
2.62 \cdot-\mathrm{F}\end{array}$ & $\begin{array}{r}\text { MCK } \\
2.52 \\
\end{array}$ & $\begin{array}{l}\text { MCK } \\
2.52-\mathrm{F}\end{array}$ & $\begin{array}{r}\text { MCK } \\
1.92\end{array}$ & $\begin{array}{l}\text { MCK } \\
1.92 \cdot \mathrm{F}\end{array}$ & $\begin{array}{l}\text { Field } \\
\text { blank }\end{array}$ & $\begin{array}{l}\text { Equip } \\
\text { blank }\end{array}$ \\
\hline Aluminum & $79.8 \mathrm{~J}^{a}$ & $48.7 \mathrm{~J}$ & $76.7 \mathrm{~J}$ & $26.9 \mathrm{~J}$ & $76.7 \mathrm{~J}$ & $61.1 \mathrm{~J}$ & $33.2 \mathrm{~J}$ & 20.0 \\
\hline Antimory & 50.0 & 50.0 & 50.0 & 50.0 & 50.0 & 50.0 & 50.0 & 50.0 \\
\hline Arsenic & 35.4 & 20.9 & 20.8 & 23.9 & 2.4 & 2.4 & 2.1 & 2.1 \\
\hline Barium & 71.7 & 67.2 & 53.4 & 48.9 & 84.1 & 82.8 & 1.3 & 1.3 \\
\hline Berylliuin & 0.30 & 0.30 & 0.30 & 0.30 & 0.30 & 0.30 & 0.30 & 0.30 \\
\hline Cadmium & 3.0 & 3.0 & 3.0 & 3.0 & 3.0 & 3.0 & 3.0 & 3.0 \\
\hline Calciurn & 46700 & 4.5900 & 46100 & 45600 & 51200 & 50400 & $93.6 \mathrm{~J}$ & 133 \\
\hline Chromilum & 10.0 & 10.0 & 10.0 & 10.0 & 10.0 & 10.0 & 10.0 & 10.0 \\
\hline Cobalt & 5.0 & 5.0 & 5.0 & 5.0 & 5.0 & 5.0 & 5.0 & 5.0 \\
\hline Copper & 4.0 & 4.0 & 4.0 & 4.0 & 8.9 & 4.0 & 4.0 & 4.0 \\
\hline Iron & 550 & 97.3 & 170 & 4.0 & 122 & 60.8 & 4.0 & 4.0 \\
\hline Lead & $0.80 \mathrm{UJ}$ & $0.80 \mathrm{UJ}$ & $0.80 \mathrm{UJ}$ & $0.80 \mathrm{UJ}$ & $0.80 \mathrm{UJ}$ & $0.80 \mathrm{UJ}$ & $0.80 \mathrm{UJ}$ & $0.80 \mathrm{UJ}$ \\
\hline Magnesium & 14400 & 14100 & 13900 & 13700 & 14500 & 14200 & $12.2 \mathrm{~J}$ & $11.6 \mathrm{~J}$ \\
\hline Manganese & 1090 & 940 & 204 & 1.0 & 5.3 .3 & 47.4 & 1.0 & 2.2 \\
\hline Mercury & 0.10 & 0.10 & 0.10 & 0.10 & 0.10 & 0.10 & 0.10 & 0.10 \\
\hline Nickel & 10.0 & 10.0 & 10.0 & 10.0 & 10.0 & 10.0 & 10.0 & 10.0 \\
\hline Niobium & $9.5 \mathrm{~J}$ & $8.7 \mathrm{~J}$ & $7.0 \mathrm{UJ}$ & $7.0 \mathrm{UJ}$ & $7.0 \mathrm{UJ}$ & $8.1 \mathrm{~J}$ & $7.0 \mathrm{UJ}$ & $7.0 \mathrm{UJ}$ \\
\hline Phosphorous & $200 \mathrm{UJ}$ & $200 \mathrm{UJ}$ & $200 \mathrm{UJ}$ & $200 \mathrm{UJ}$ & $200 \mathrm{UJ}$ & $200 \mathrm{UJ}$ & $200 \mathrm{UJ}$ & $200 \mathrm{UJ}$ \\
\hline Potassium & 4700 & 4.510 & 4720 & 4920 & 2410 & 2490 & 600 & 600 \\
\hline Selenium & $2.0 \mathrm{UJ}$ & $2.0 \mathrm{UJ}$ & $2.0 \mathrm{UJ}$ & $2.0 \mathrm{UJ}$ & $2.0 \mathrm{UJ}$ & $2.0 \mathrm{UJ}$ & $2.0 \mathrm{UJ}$ & $2.0 \mathrm{UJ}$ \\
\hline Silver & 6.0 & 6.0 & 6.0 & 6.0 & 6.0 & 6.0 & 6.0 & 6.0 \\
\hline Sodium & 2960 & 2800 & 2780 & 2890 & 2020 & 1890 & 248 & 274 \\
\hline Vanadium & 5.0 & 5.0 & 5.0 & 5.0 & 5.0 & 5.0 & 5.0 & 5.0 \\
\hline Zinc & $7.0 \mathrm{~J}$ & $5.4 \mathrm{~J}$ & 15.3 & $4.7 \mathrm{~J}$ & $9.1 \mathrm{~J}$ & $5.1 \mathrm{~J}$ & $2.4 \mathrm{~J}$ & $6.3 \mathrm{~J}$ \\
\hline
\end{tabular}

$a_{\mathrm{J}}=$ estimated value; $\mathrm{R}=$ rejected value; $\mathrm{U}=$ undetected-below method detection level. 


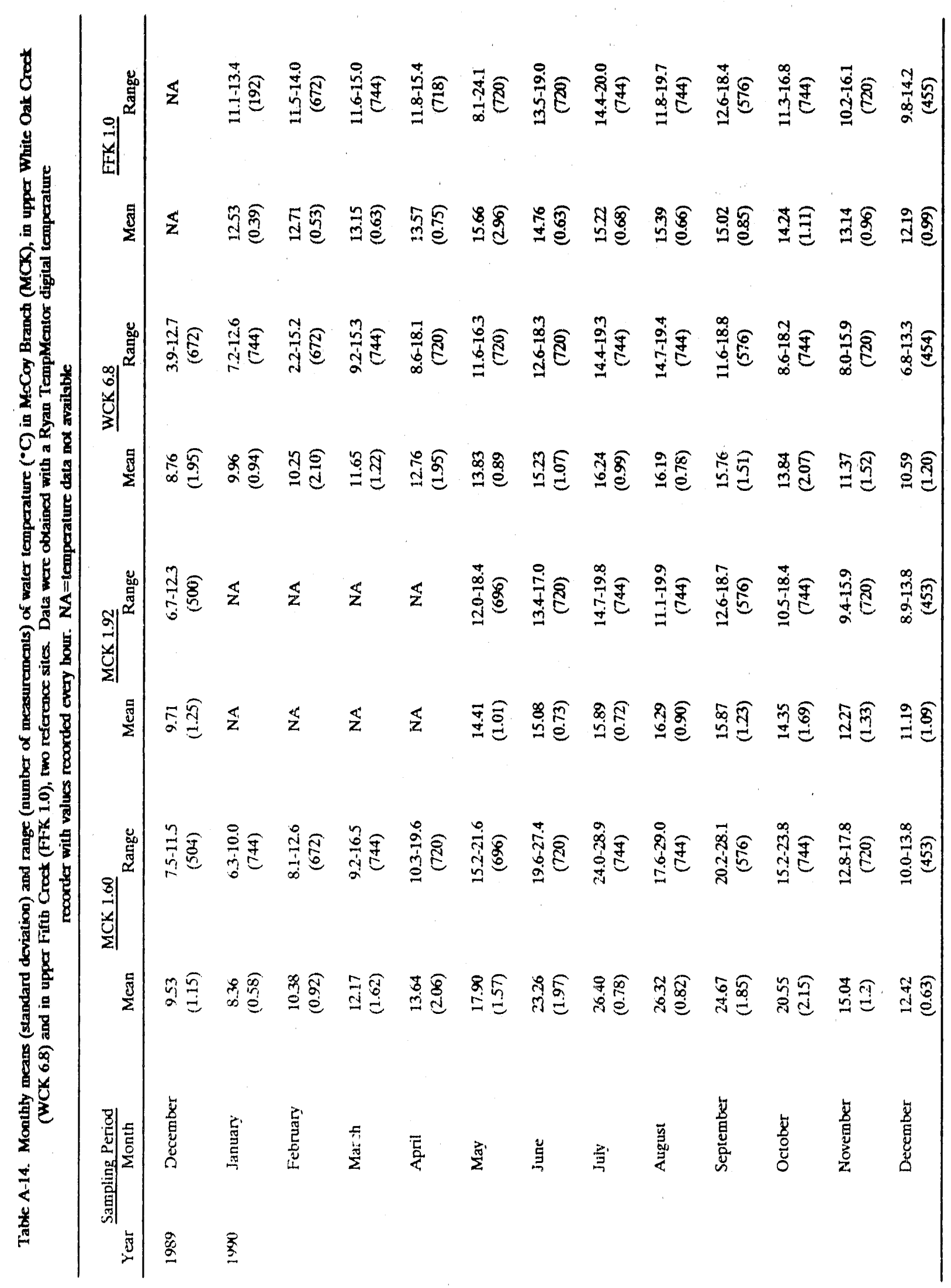


Table A-15. Sediment analyses for McCoy Branch, October 1974-January 1975.

Stations 1 (200 $\mathrm{m}$ above Rogers Quarry), 2 (200 m below the quarry) and C (Control site on western branch of McCoy Branch. $A A=$ Atomic absorption spectroscopy; units are $\mu \mathrm{g} / \mathrm{g}$. $\mathrm{ES}=$ emission spectroscopv; units are percent. Source: ERDA 1975

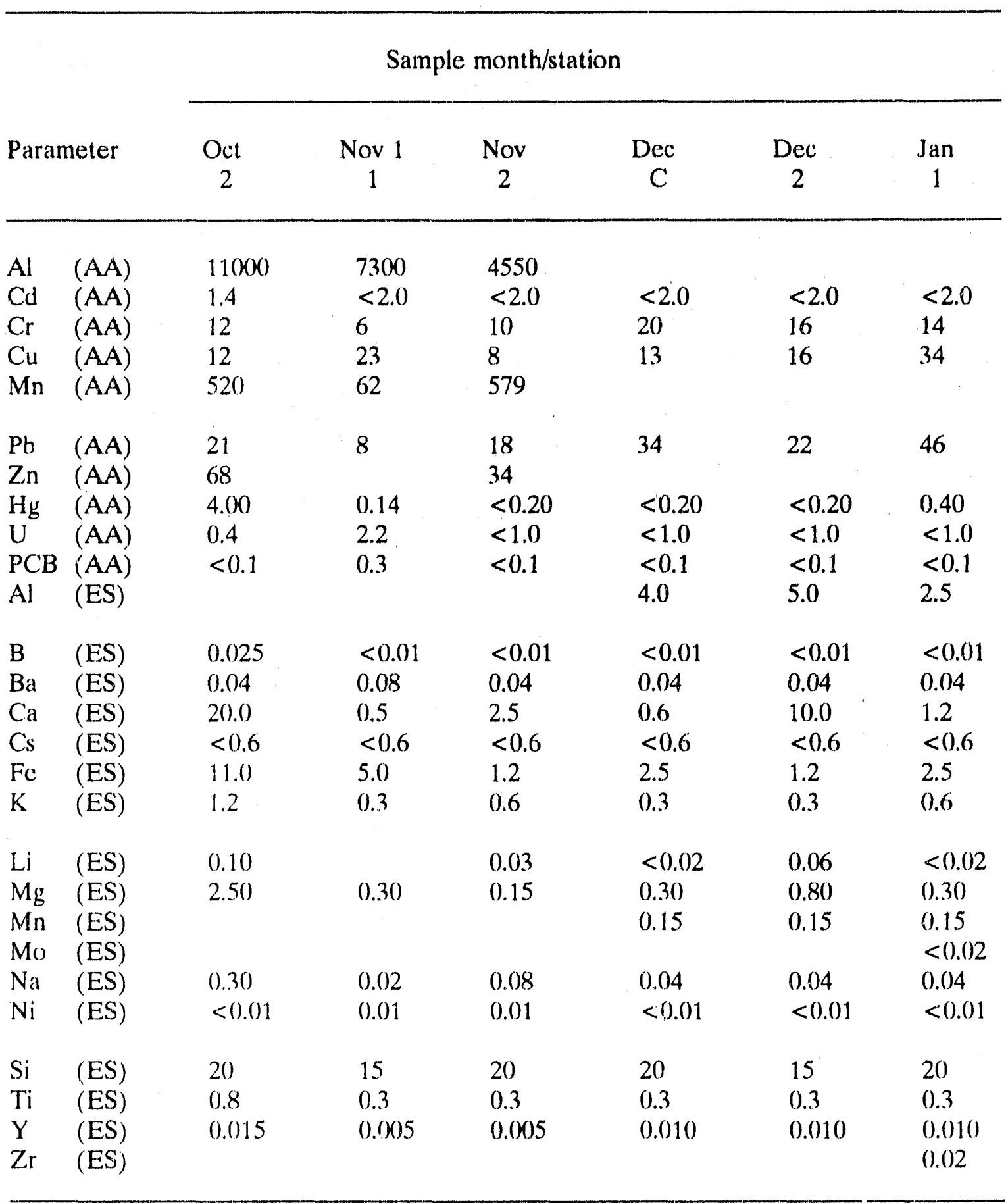




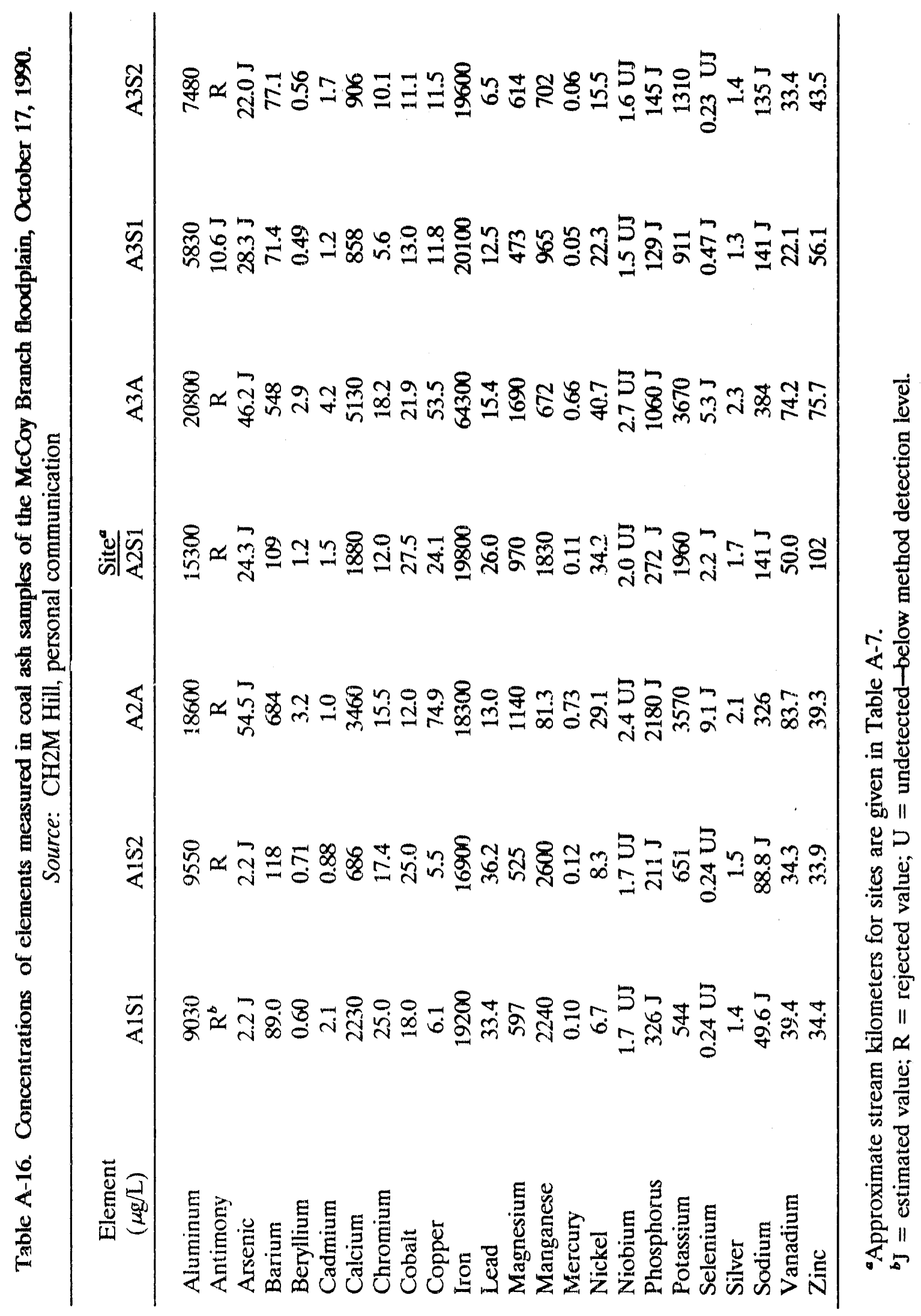




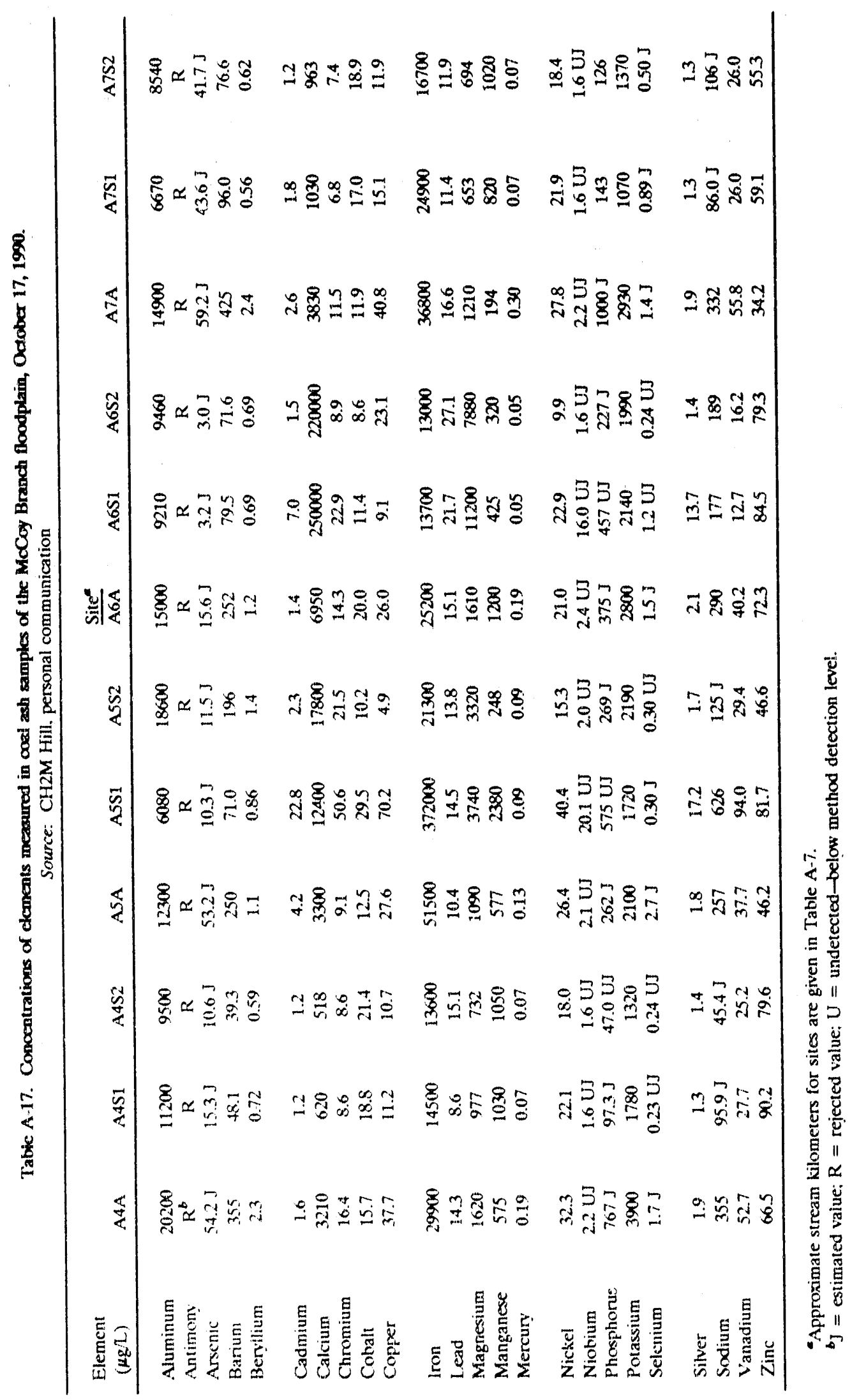




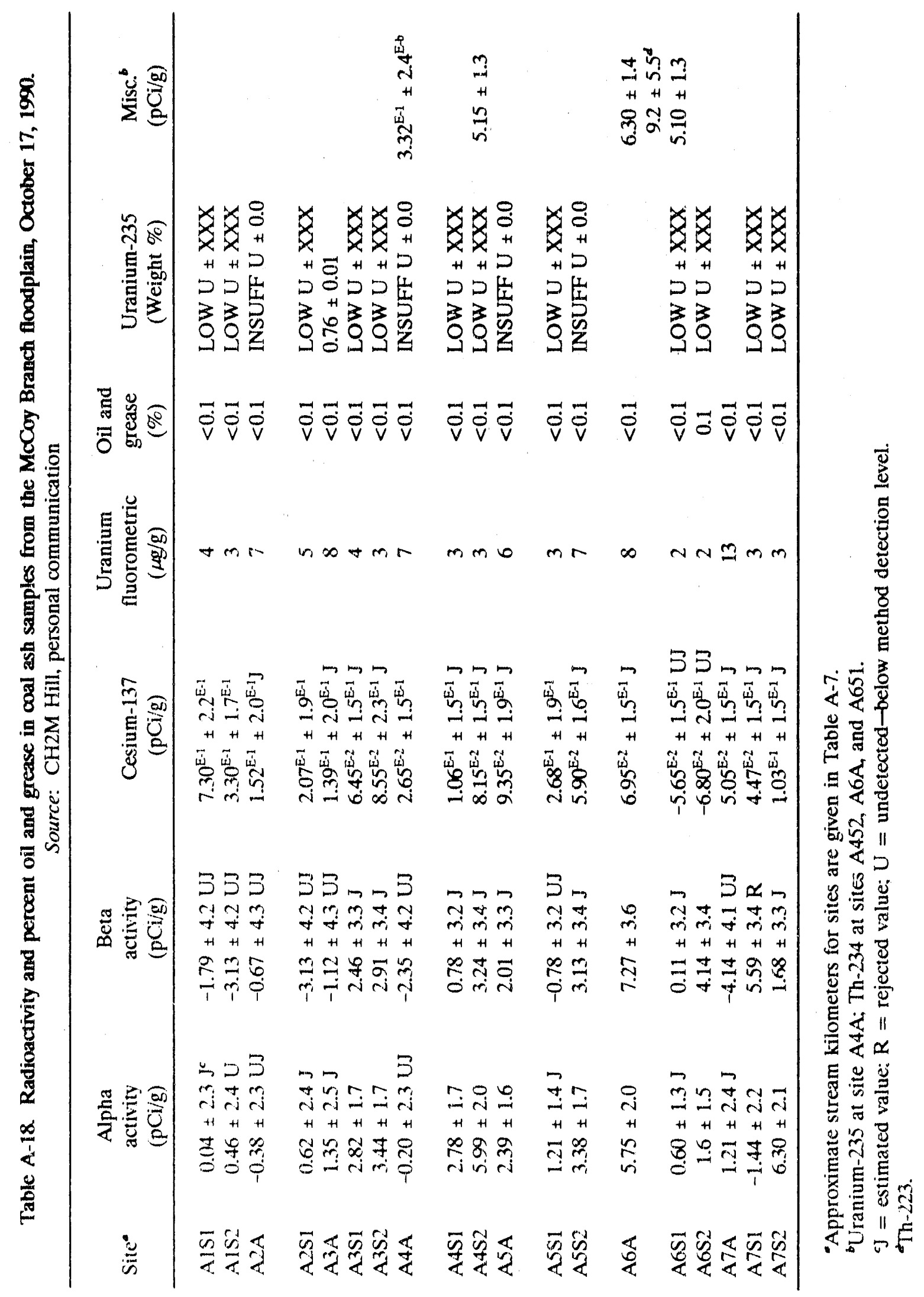




$$
\begin{aligned}
& \text { A-26 }
\end{aligned}
$$

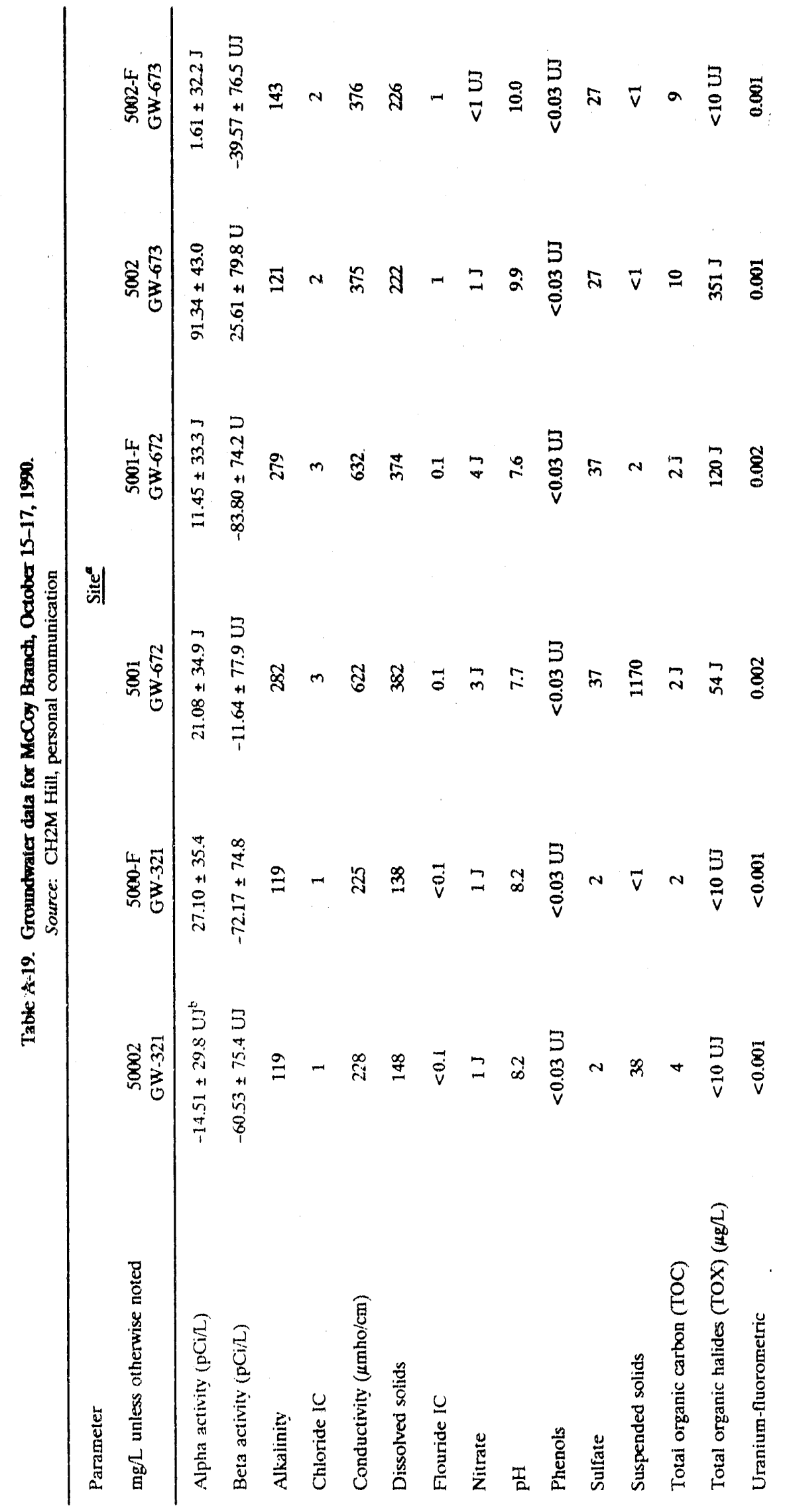




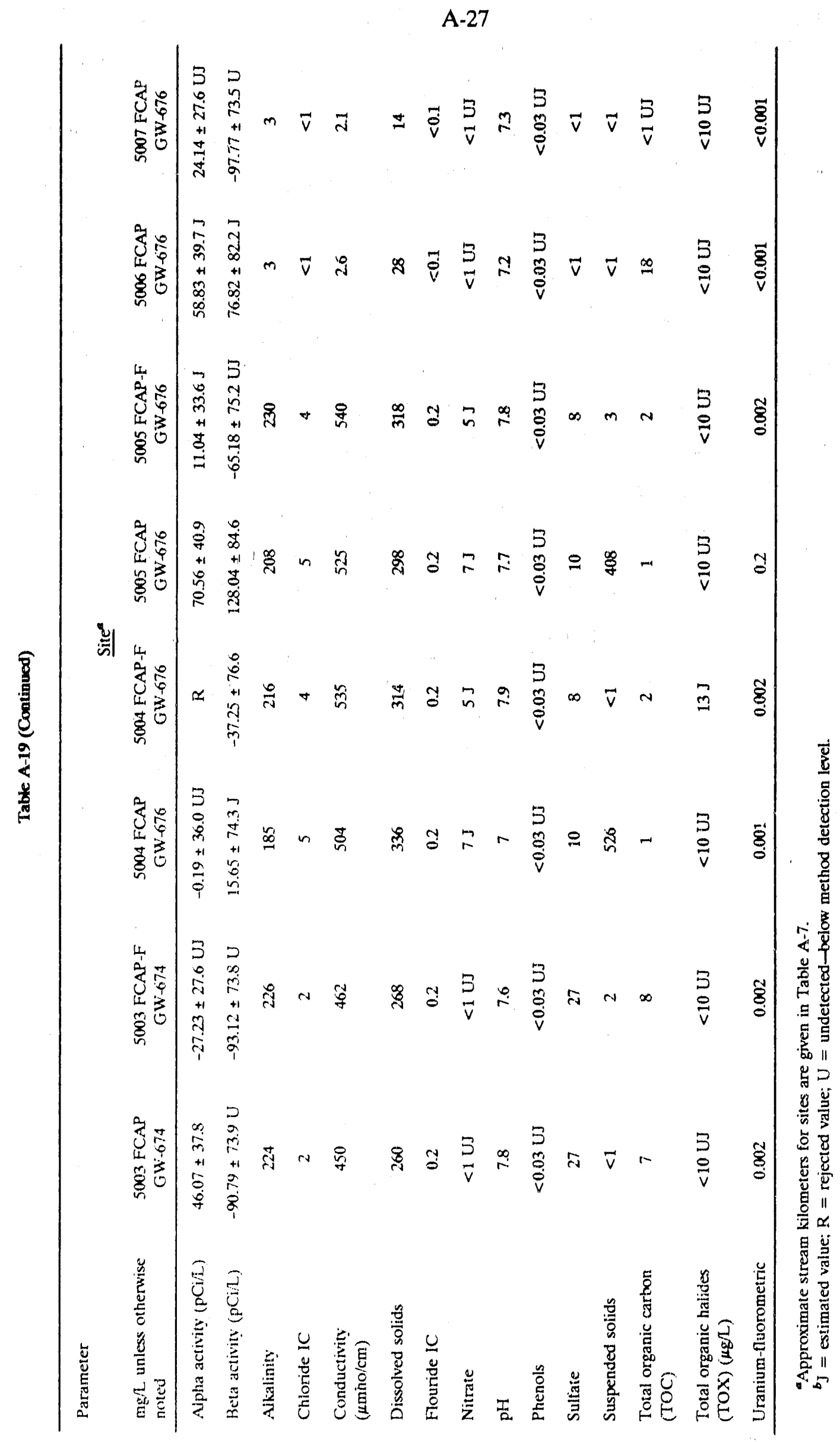




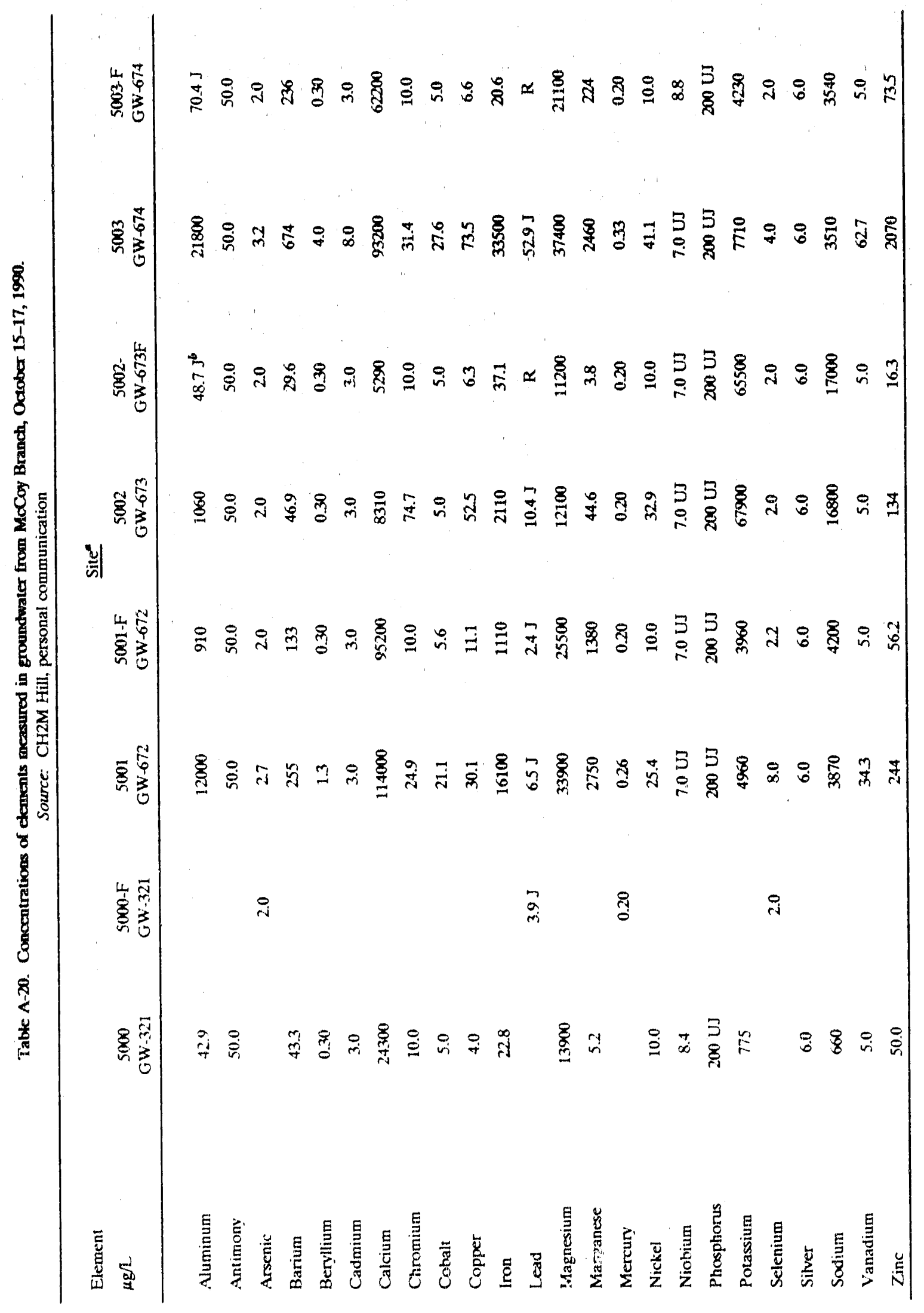




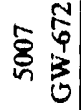

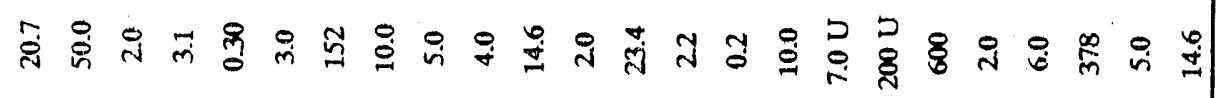

崖岁是

$\stackrel{i}{i}$

ำ

i

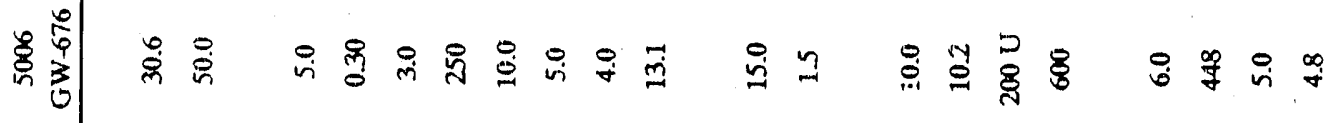

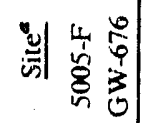

ผ

空紊

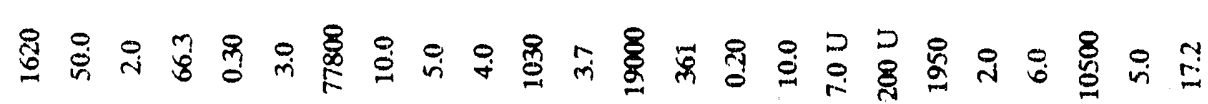

तं

올 옹

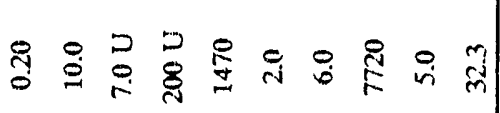

$\stackrel{8}{=} \stackrel{0}{=} \dot{0} \equiv$

i.

\&్

$\overline{2}$

尽茄兽

엉

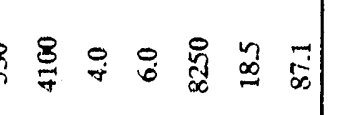

章

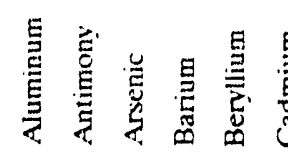

II

Inn

Hun: 


\section{APPENDIX B \\ CHECKLIST OF BENTHIC MACROINVERTEBRATE TAXA FROM MCCOY BRANCH AND WHITE OAK CREEK, APRIL 1989-JANUARY 1990}




\section{B-3}

Table B-1. Checklist of benthic macroinvertebrate taxa collected from McCoy Branch (MCK) and White Oak Creek (WCK), a reference stream, April 1989-January 1990.

The ' $\mathrm{X}$ ' indicates that the taxon was collecterl at least once in quantitative samples during the sampling period.

'The ' $Q$ ' indicates that the taxon was collected in qualitative samples only

\begin{tabular}{|c|c|c|c|}
\hline \multirow[b]{2}{*}{ Taxon } & \multicolumn{3}{|c|}{ Site } \\
\hline & $\begin{array}{l}\text { MCK } \\
1.40\end{array}$ & $\begin{array}{l}\text { MCK } \\
2.03\end{array}$ & $\begin{array}{l}\text { WCK } \\
6.8\end{array}$ \\
\hline $\begin{array}{l}\text { Coelenterata (hydras) } \\
\text { Hydridae } \\
\text { Hydra }\end{array}$ & & & $X$ \\
\hline $\begin{array}{l}\text { Turbellaria } \\
\text { Tricladida } \\
\text { Planariidae (flat worms) }\end{array}$ & X & $X$ & $X$ \\
\hline Copepoda (copepods) & $\mathrm{X}$ & & \\
\hline Nematoda (roundworms) & $\mathrm{X}$ & & $\mathrm{X}$ \\
\hline $\begin{array}{l}\text { Annelida } \\
\quad \text { Oligochaeta (aquatic earthworms) }\end{array}$ & X & $X$ & X \\
\hline Ostracoda (seed shrimp) & $\mathrm{x}$ & $\mathrm{X}$ & \\
\hline $\begin{array}{l}\text { Crustacea } \\
\text { Amphipoda (sideswimmers) } \\
\text { Gammaridae }\end{array}$ & & & \\
\hline $\begin{array}{c}\text { Crangonyx } \\
\text { Decapoda (crayfish) }\end{array}$ & & $\mathrm{Q}$ & $\begin{array}{l}\mathrm{X} \\
\mathrm{X}\end{array}$ \\
\hline $\begin{array}{c}\text { Cambaridae } \\
\text { Cambarus } \\
\text { Hydracarina (water mites) }\end{array}$ & Q & $\begin{array}{l}Q \\
X\end{array}$ & $\begin{array}{l}X \\
Q \\
X\end{array}$ \\
\hline $\begin{array}{l}\text { Insecta } \\
\text { Collembola (springtails) } \\
\text { Anthropleona }\end{array}$ & & & \\
\hline $\begin{array}{l}\text { Entomobryomorpha } \\
\text { Sminthuridae }\end{array}$ & $\begin{array}{l}X \\
X\end{array}$ & $x$ & $X$ \\
\hline
\end{tabular}


Table B-1 (Continused)

\begin{tabular}{|c|c|c|c|}
\hline \multirow[b]{2}{*}{ Taxon } & \multicolumn{3}{|c|}{ Site } \\
\hline & $\begin{array}{l}\overline{M C K} \\
1.40\end{array}$ & $\begin{array}{l}\mathrm{MCK} \\
2.03\end{array}$ & $\begin{array}{l}\text { WCK } \\
6.8\end{array}$ \\
\hline \multicolumn{4}{|l|}{ Ephemeroptera (mayflies) } \\
\hline Baetidae? & & & $\mathrm{X}$ \\
\hline Baetidae & & $\mathrm{X}$ & \\
\hline Baetis & $\mathrm{X}$ & $\mathrm{X}$ & $X$ \\
\hline Baetis pluto & & & $\mathrm{Q}$ \\
\hline Baetis tricaudatus & $\mathbf{Q}$ & & $Q$ \\
\hline Pseudocloeon & $\mathrm{X}$ & & $\mathrm{X}$ \\
\hline Ephemerellidae & & & $X$ \\
\hline Ephemerella & & $\mathrm{X}$ & $\mathrm{X}$ \\
\hline Ephemerella? & & & $\mathrm{Q}$ \\
\hline Ephemerella invaria & & & $Q$ \\
\hline Eurylophella & $\mathrm{X}$ & $\mathrm{X}$ & $\mathrm{X}$ \\
\hline Eurylophella doris/temporalis & & & $\mathrm{Q}$ \\
\hline \multicolumn{4}{|l|}{ Ephemeridae } \\
\hline Ephemera & & & $X$ \\
\hline Heptageniidac & & & $\mathrm{X}$ \\
\hline Stenacron & & & $\mathrm{X}$ \\
\hline Stenacron interpunctatum & & & $\mathrm{Q}$ \\
\hline Stenonema & & & $\mathrm{X}$ \\
\hline Stenonema!! & & & $x$ \\
\hline Leptophlebiidae & & $\mathrm{X}$ & $\mathrm{X}$ \\
\hline Habrophlebiodes & $X$ & $\mathrm{X}$ & $\mathrm{X}$ \\
\hline Paraleptophlebia & & & $\mathrm{X}$ \\
\hline \multicolumn{4}{|l|}{ Oligoneuriidae } \\
\hline Isonychia & & & $\mathrm{X}$ \\
\hline \multicolumn{4}{|l|}{ Odonata } \\
\hline \multicolumn{4}{|l|}{ Anisoptera (dragonflies) } \\
\hline \multicolumn{4}{|l|}{ Aeshnidae } \\
\hline Boyeria & & $Q$ & \\
\hline \multicolumn{4}{|l|}{ Cordulegastridae } \\
\hline Cordulegaster & & $\mathrm{X}$ & \\
\hline Gomphidae & & & $x$ \\
\hline Stylogomphus & & $X$ & $x$ \\
\hline Stylogomphus albistylus & & & $Q$ \\
\hline Stylogomphus? & & & $X$ \\
\hline Libellulidac & $x$ & & \\
\hline Zygoptera (damselflies) & & & \\
\hline
\end{tabular}


B-5

Table B-1 (Continued)

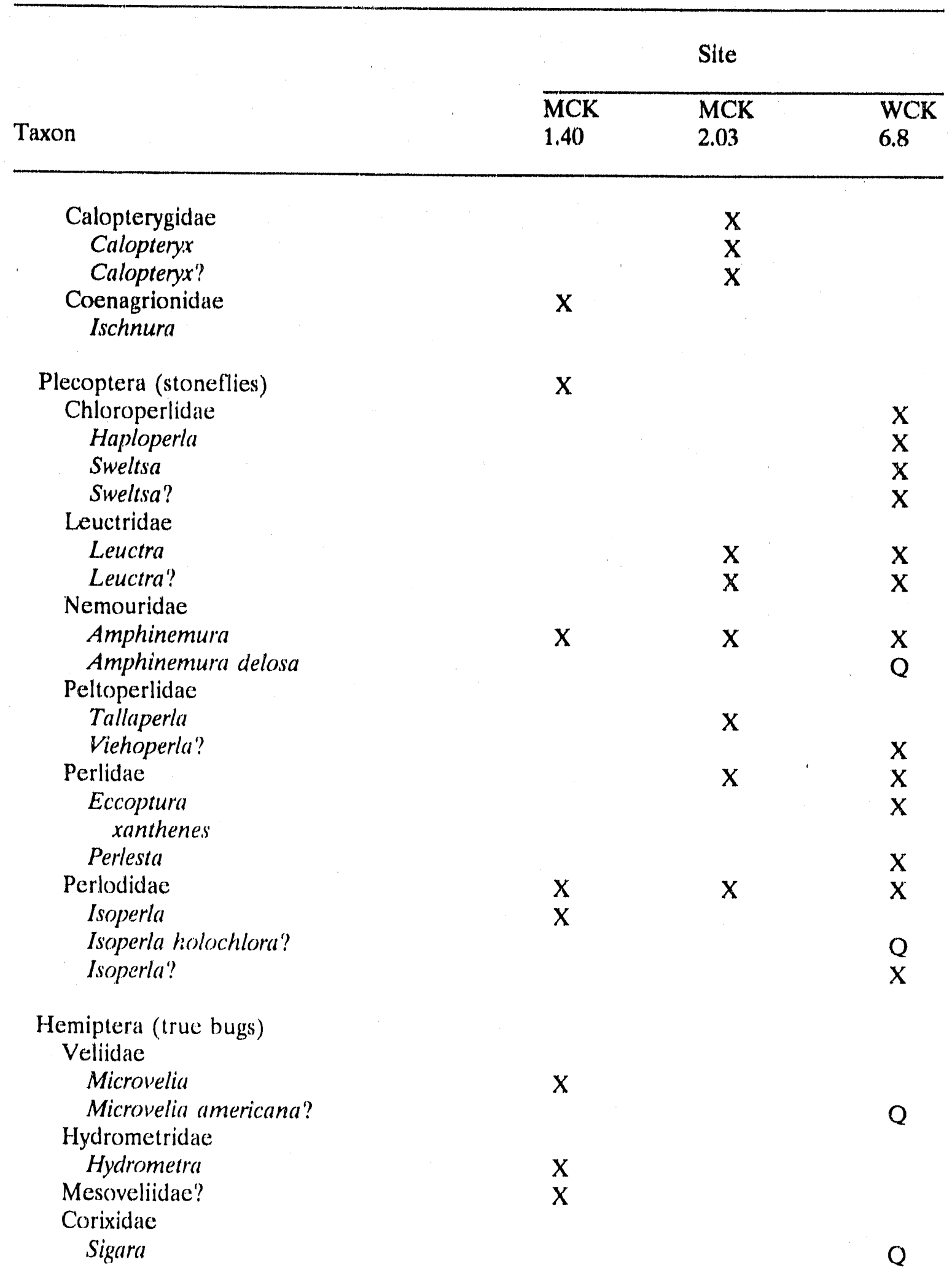


Table B-1 (Continued)

\begin{tabular}{|c|c|c|c|}
\hline \multirow{2}{*}{ Taxon } & \multicolumn{3}{|c|}{ Site } \\
\hline & $\overline{\mathrm{MCK}}$ & $\begin{array}{l}\text { MCK } \\
2.03\end{array}$ & $\begin{array}{l}\text { WCK } \\
6.8\end{array}$ \\
\hline \multicolumn{4}{|l|}{ Megaloptera } \\
\hline \multicolumn{4}{|c|}{ Corydalidae (dobsonflies, fishflies) } \\
\hline Nigronia & & $\mathrm{X}$ & $\mathrm{X}$ \\
\hline $\begin{array}{l}\text { Nigronia } \\
\text { fasciatus }\end{array}$ & & & $\mathrm{x}$ \\
\hline $\begin{array}{l}\text { Nigronia } \\
\text { serricornis }\end{array}$ & & & $\mathrm{x}$ \\
\hline \multicolumn{4}{|l|}{ Sialidae (alderflies) } \\
\hline Sialis & & & $\mathrm{x}$ \\
\hline Trichoptera (caddisflies) & $\mathrm{X}$ & & $\mathrm{x}$ \\
\hline \multicolumn{4}{|l|}{ Glossosomatidae } \\
\hline Agapetus & & & $\mathrm{x}$ \\
\hline Glossosoma & & $\mathrm{x}$ & \\
\hline Hydropsychidae & $\mathrm{x}$ & $\mathrm{x}$ & $\mathrm{x}$ \\
\hline Cheumatopsy:he & $\mathbf{X}$ & $\mathrm{x}$ & $\mathrm{X}$ \\
\hline $\begin{array}{l}\text { Diplectrona } \\
\text { modesta }\end{array}$ & & $\mathrm{x}$ & $\mathrm{x}$ \\
\hline Hydropsyche & $\mathrm{x}$ & $\mathrm{x}$ & $\mathrm{x}$ \\
\hline Hydropsyche? & & & $\mathrm{x}$ \\
\hline \multicolumn{4}{|l|}{ Hydroptilidae } \\
\hline Hydroptila & $\mathrm{X}$ & $\mathrm{X}$ & $\mathrm{x}$ \\
\hline \multicolumn{4}{|l|}{ Limnephilidae } \\
\hline Neophylax & $\mathrm{X}$ & $\mathrm{x}$ & $\mathrm{x}$ \\
\hline Pycnopsyche & $\mathrm{x}$ & $\mathrm{x}$ & \\
\hline Pycnopsyche gentilis & & & $\mathrm{Q}$ \\
\hline Pycnopsyche luculenta & & & $\mathrm{Q}$ \\
\hline \multirow{2}{*}{\multicolumn{4}{|c|}{$\begin{array}{l}\text { Odontoceridae } \\
\text { Odidents }\end{array}$}} \\
\hline & & & \\
\hline Psilotreta & & & $\mathrm{x}$ \\
\hline \multicolumn{4}{|l|}{ Philopotamidac: } \\
\hline Chimarra & $\mathrm{x}$ & $\mathrm{x}$ & $\mathrm{x}$ \\
\hline $\begin{array}{l}\text { Dolophilodes } \\
\text { distinctus }\end{array}$ & & & $\mathrm{x}$ \\
\hline Wormaldia & & $\mathrm{X}$ & $\mathrm{X}$ \\
\hline Molannidae & & & \\
\hline Molanna & & $\mathrm{x}$ & \\
\hline
\end{tabular}


B.7

Table B-1 (Continued)

\begin{tabular}{|c|c|c|c|}
\hline \multirow[b]{2}{*}{ Taxon } & \multicolumn{3}{|c|}{ Site } \\
\hline & $\begin{array}{l}\mathrm{MCK} \\
1.40\end{array}$ & $\begin{array}{l}\text { MCK } \\
2.03\end{array}$ & $\begin{array}{l}\text { WCK } \\
6.8\end{array}$ \\
\hline \multicolumn{4}{|l|}{ Polycentropodidae } \\
\hline Polycentropus & $\mathrm{X}$ & & $X$ \\
\hline Polycentropus? & & & $\mathbf{X}$ \\
\hline Psychomyiidae & & 1. & \\
\hline Lype diversa & & $\mathbf{X}$ & \\
\hline \multicolumn{4}{|l|}{ Rhyacophilidae } \\
\hline Rhyacophila & & & $\mathrm{X}$ \\
\hline \multicolumn{4}{|l|}{ Goeridae } \\
\hline Goera & & & $\mathbf{X}$ \\
\hline \multicolumn{4}{|l|}{ Lepidostomatidae } \\
\hline Lepidostoma & & $\mathrm{X}$ & $\mathrm{X}$ \\
\hline \multicolumn{4}{|l|}{ Coleoptera (beetles) } \\
\hline \multicolumn{4}{|l|}{ Dryopidae } \\
\hline Helichus fastigiatus & & & $Q$ \\
\hline Elmidae & $\mathbf{X}$ & $\mathrm{X}$ & \\
\hline Dubiraphia & & & $Q$ \\
\hline Optiosemus & $X$ & $\mathrm{X}$ & $\mathrm{X}$ \\
\hline Stenelmis & $X$ & $\mathrm{X}$ & $\mathrm{X}$ \\
\hline Stenelmis? & $\mathrm{X}$ & & \\
\hline $\begin{array}{l}\text { Microcylloepus } \\
\text { pusillus }\end{array}$ & $\mathrm{X}$ & $\mathrm{X}$ & \\
\hline \multicolumn{4}{|l|}{ Eubrildae } \\
\hline Ectopria & & & $\mathrm{X}$ \\
\hline \multicolumn{4}{|l|}{ Hydrophilidae } \\
\hline Hydrobius & & $Q$ & \\
\hline \multicolumn{4}{|l|}{ Psephenidae } \\
\hline $\begin{array}{c}\text { Psephenus } \\
\text { herricki }\end{array}$ & $\mathrm{X}$ & & $\mathrm{X}$ \\
\hline \multicolumn{4}{|l|}{ Ptilodactylidac } \\
\hline $\begin{array}{c}\text { Anchytarsus } \\
\text { bicolor }\end{array}$ & $\mathrm{X}$ & & $\mathrm{x}$ \\
\hline Diptera (true flies) & $\mathrm{X}$ & & $x$ \\
\hline Muscomorpha & $\mathrm{X}$ & & \\
\hline Ceratopogonidae & $\mathrm{X}$ & $\mathrm{X}$ & $\mathrm{X}$ \\
\hline Atrichopogron & & $\mathbf{X}$ & \\
\hline
\end{tabular}


B-8

Table B-1 (Continued)

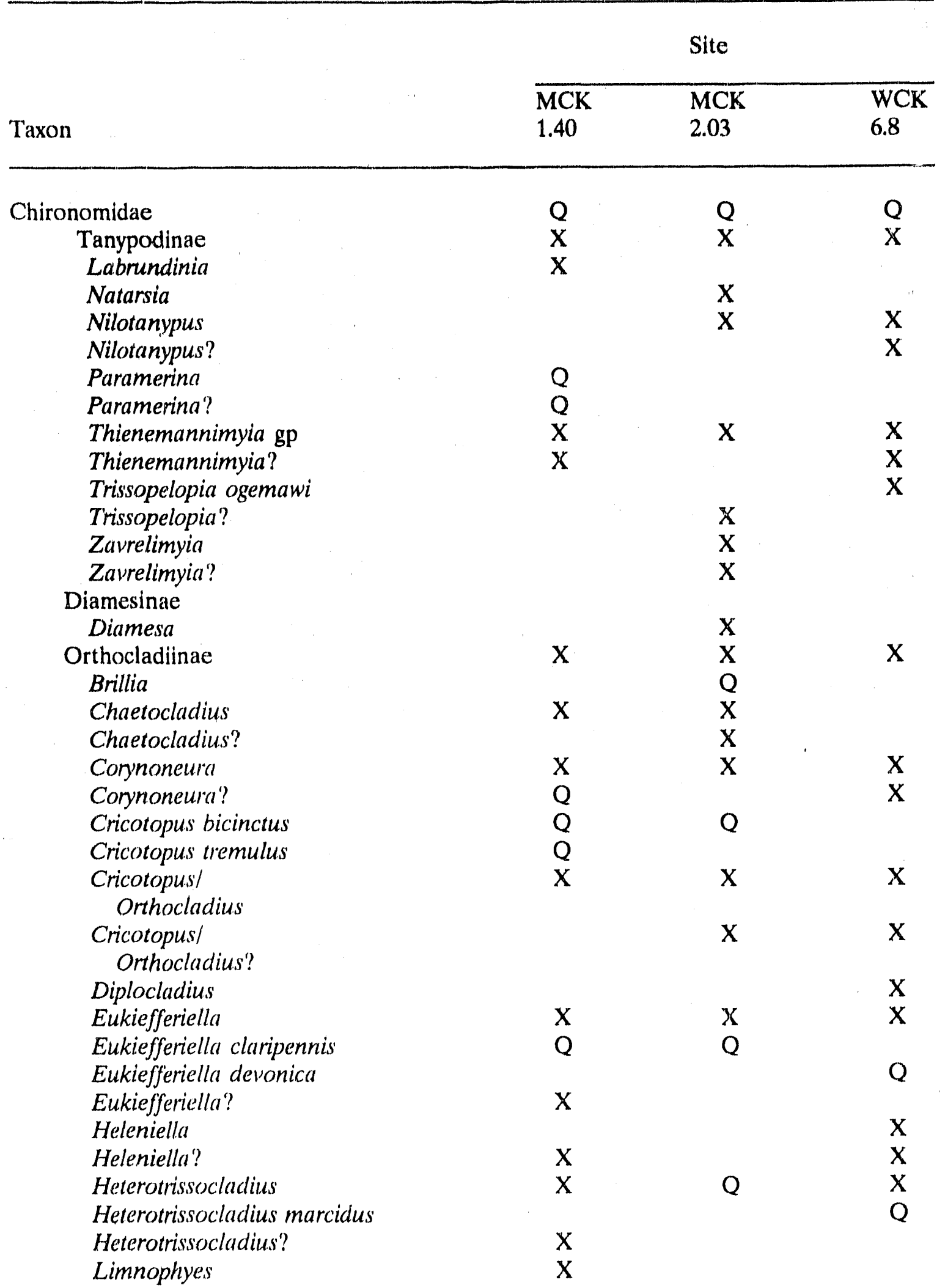


B-9

Table B-1 (Continued)

\begin{tabular}{|c|c|c|c|}
\hline \multirow[b]{2}{*}{ Taxon } & \multicolumn{3}{|c|}{ Site } \\
\hline & $\begin{array}{l}\mathrm{MCK} \\
1.40\end{array}$ & $\begin{array}{l}\text { MCK } \\
2.03\end{array}$ & $\begin{array}{l}\text { WCK } \\
6.8\end{array}$ \\
\hline Lopescladius & & & $\mathbf{X}$ \\
\hline Nanocladius & $\mathbf{X}$ & & \\
\hline Parakiefferiella & $\mathbf{X}$ & & \\
\hline Parametriocnemus & $\mathbf{X}$ & $\mathbf{X}$ & $\mathbf{X}$ \\
\hline Psectrocladius & & $\mathrm{X}$ & \\
\hline Rheocricotopus & & & $X$ \\
\hline Smittia & $\mathbf{X}$ & $\mathbf{X}$ & \\
\hline Symposiocladius & $\mathrm{X}$ & $Q$ & \\
\hline Thienemanniella & $X$ & $\mathrm{X}$ & $\mathrm{X}$ \\
\hline Tvetenia & $\mathrm{X}$ & $\mathrm{X}$ & $\mathrm{X}$ \\
\hline Tvetenia bavarica & $Q$ & & $Q$ \\
\hline Chironominae & $\mathrm{X}$ & $\mathrm{X}$ & $\mathrm{X}$ \\
\hline \multicolumn{4}{|l|}{ Chironomini } \\
\hline Chironomus/Einfeldia & & Q & \\
\hline Cryptochironomus & $\mathrm{X}$ & $\mathrm{X}$ & $\mathrm{X}$ \\
\hline Dicrotendipes & $Q$ & $\mathrm{X}$ & \\
\hline Microtendipes & $\mathrm{Q}$ & & $X$ \\
\hline Microtendipes? & & & $\mathbf{X}$ \\
\hline Paralauterborniella & & & $Q$ \\
\hline Paratendipes & $\mathrm{X}$ & $X$ & \\
\hline Paratendipes? & & $\mathrm{X}$ & \\
\hline Polypedilum & $X$ & $\mathrm{X}$ & $\mathrm{X}$ \\
\hline Stictochironomus & Q & & \\
\hline Tanytarsini & $Q$ & $X$ & \\
\hline Micropsectia & $\mathrm{X}$ & $\mathrm{X}$ & $X$ \\
\hline Micropsectra? & $X$ & $X$ & $\mathrm{X}$ \\
\hline Paratanytarsus & $Q$ & & \\
\hline Paratanytarsus? & & $\mathrm{X}$ & \\
\hline Rheotanytarsus & $\mathrm{X}$ & $\mathrm{X}$ & $\mathrm{X}$ \\
\hline Rheotonytarsus? & & $\mathrm{X}$ & $\mathrm{X}$ \\
\hline Stempellina & & & $\mathrm{X}$ \\
\hline Stempellinella & $\mathrm{X}$ & $X$ & $\mathrm{X}$ \\
\hline Stempellinella? & & $\mathrm{X}$ & $\mathrm{X}$ \\
\hline \multicolumn{4}{|l|}{ Culicidae } \\
\hline Anopheles & $X$ & & \\
\hline \multicolumn{4}{|l|}{ Dixidae } \\
\hline Dixa & & $\mathrm{X}$ & $\mathrm{X}$ \\
\hline Dolichopodidae & $Q$ & $Q$ & $Q$ \\
\hline Sciomyzidae & & $\mathrm{X}$ & \\
\hline
\end{tabular}


B-10

Table B-1 (Continued)

\begin{tabular}{|c|c|c|c|}
\hline \multirow[b]{2}{*}{ Taxon } & \multicolumn{3}{|c|}{ Site } \\
\hline & $\begin{array}{l}\overline{M C K} \\
1.40\end{array}$ & $\begin{array}{l}\text { MCK } \\
2.03\end{array}$ & $\begin{array}{l}\text { WCK } \\
6.8\end{array}$ \\
\hline \multicolumn{4}{|l|}{ Simuliidae } \\
\hline Simulium & $\mathrm{X}$ & $\mathrm{X}$ & $\mathrm{X}$ \\
\hline Simulium? & & & $Q$ \\
\hline Muscidae & $\mathrm{x}$ & & \\
\hline \multicolumn{4}{|l|}{ Empididae } \\
\hline Chelifera & $\mathrm{X}$ & Q & $\mathrm{X}$ \\
\hline Clinocera & & $\mathrm{Q}$ & $X$ \\
\hline Hemerodromia & $\mathrm{X}$ & $X$ & $X$ \\
\hline Hemerodromia? & & & $\mathrm{X}$ \\
\hline \multicolumn{4}{|l|}{ Psychodidae } \\
\hline Pericoma & & & $\mathrm{X}$ \\
\hline Stratiomyidae & & $\mathrm{X}$ & \\
\hline Caloparyphus & & $\mathrm{X}$ & \\
\hline Myxosargus & $\mathrm{X}$ & & \\
\hline Nemotelus & & $\mathrm{Q}$ & \\
\hline Odontomyia & $\mathrm{X}$ & & \\
\hline \multicolumn{4}{|l|}{ Tabanidae } \\
\hline Chrysops & $X$ & & \\
\hline Tabanus & & $Q$ & \\
\hline Tipulidae & & $\mathrm{X}$ & \\
\hline Antocha & & & $\mathrm{X}$ \\
\hline Hexatoma & & & $\mathrm{X}$ \\
\hline Limnophila & & & $Q$ \\
\hline Limnophila? & & & $X$ \\
\hline \multicolumn{4}{|l|}{ Polymera } \\
\hline Pseudolimnophila & $X$ & $X$ & $X$ \\
\hline Pseudolimnophila? & & & $\mathrm{X}$ \\
\hline Tipula & $X$ & $X$ & $\mathrm{X}$ \\
\hline Tipula abdominalis & & & $\mathrm{X}$ \\
\hline \multicolumn{4}{|l|}{ Mollusca } \\
\hline Gastropoda (snails) & $\mathrm{X}$ & $\mathrm{X}$ & $\mathrm{X}$ \\
\hline Lymnaeidae & $X$ & & \\
\hline Pseudosuccinea columella & $\mathrm{Q}$ & $Q$ & \\
\hline Lymnaeidae? & $\mathrm{X}$ & $X$ & \\
\hline \multicolumn{4}{|l|}{ Physidae } \\
\hline Physella & $X$ & $\mathrm{X}$ & \\
\hline Planorbidae & $\mathrm{X}$ & & \\
\hline Gyraulas & $x$ & & \\
\hline
\end{tabular}


B-11

Table B-1 (Continued)

\begin{tabular}{|c|c|c|c|}
\hline \multirow[b]{2}{*}{ Taxon } & \multicolumn{3}{|c|}{ Site } \\
\hline & $\begin{array}{l}\overline{\mathrm{MCK}} \\
1.40\end{array}$ & $\begin{array}{l}\mathrm{MCK} \\
2.03\end{array}$ & $\begin{array}{l}\text { WCK } \\
6.8\end{array}$ \\
\hline $\begin{array}{l}\text { Pleuroceridae } \\
\text { Elimia }\end{array}$ & & & $X$ \\
\hline $\begin{array}{l}\text { Bivalvia (clams) } \\
\text { Sphaeriidae } \\
\text { Pisidium } \\
\text { Pisidium? } \\
\text { Sphaerium } \\
\text { Corbicula fluminea }\end{array}$ & $\begin{array}{l}X \\
X\end{array}$ & $X$ & $\begin{array}{l}X \\
X \\
X \\
X\end{array}$ \\
\hline
\end{tabular}


ORNL/TM-11926

\section{INTERNAL DISTRIBUTION}

1. L. J. Allison

2. T. L. Ashwood

3. B. G. Blaylock

4. W. R. Brown

5. G. F. Cada

6. S. W. Christensen

7. R. B. Clapp

8. R. B. Cook

9. M. F. P. Delozier

10. M. L. Frank

11. C. W. Gehrs

12. S. G. Hildebrand

13. C. C. Hill

14. R. L. Hinzman

15. M. A. Huston

16. P. Kanciruk

17. B. L. Kimmel

18. J. M. Loar

19. R. B. McLean

20. L. W. McMahon

21. M. J. Peterson

22-29. M. G. Ryon

30. J. A. Shaakir-Ali

31. F. E. Sharples
32. E. M. Schilling

33. L. R. Shugart

34. J. G. Smith

35. G. R. Southworth

36. C. L. Stair

37. A. J. Stewart

38. J. E. Stone

39. G. W. Suter

40. D. W. Swindle

41. V. R. Tolbert

42. J. R. Trabalka

43. R. R. Turner

44. W. Van Winkle

45. L. D. Voorhees

46. S. Walker

47. R. K. White

48. Central Research Library

49-63. ESD Library

64-67. ER Document Management $\mathrm{Ctr}$

68-69. Laboratory Records Department

70. Laboratory Records-RC

71. ORNL Patent Office

72. ORNL Y-12 Technical Library

\section{EXTERNAL DISTRIBUTION}

73. S. Ahlstedt, Division of Water Resources, Tennessee Valley Authority, Norris, TN 37828

74. D. S. Day, Environmental Division, U.S. Department of Energy, Savannah River Operations Office, Box A, Aiken, SC 29802

75. P. H. Edmonds, Radian Corporation, 120 South Jefferson Circle, Oak Ridge, TN 37830

76. W. Fisher, Department of Zoology, Oklahoma State University, Stillwater, OK 74078

77. J. F. Franklin, Bloedel Professor of Ecosystem Analysis, College of Forest Resources, University of Washington, Anderson Hall (AR-10), Seattle, WA 98195

78. C. S. Gist, Environmental Protection Division, SE-31, DOE Oak Ridge Field Office, Oak Ridge, P.O. Box 2001, Oak Ridge, TN 37831

79. H. W. Hibbitts, Deputy Assistant Manager, Department of Environment, Safety and Quality, SE-30, DOE Oak Ridge Field Office, P.O. Box 2001, Oak Ridge, TN 37830

80. D. R. Hopkins, U.S. Environmental Protection Agency, 345 Courtland Street, N.E., Atlanta, GA 30.365

81. G. M. Hornberger, Professor, Department of Environmental Sciences, University of Virginia, Charlottesville, VA 22903 
82. G. Y. Jordy, Director, Office of Program Analysis, Office of Energy Research, ER-30, G-226, U.S. Department of Energy, Washington, DC 20545

83. T. Joseph, Environmental Remediation Branch, Environmental Protection Division, SE-312, DOE Oak Ridge Field Office, P.O. 2001, Oak Ridge, TN 37830

84. R. A. Jump, Environmental Restoration Division, EW-91, DOD Oak Ridge Field Office, P.O. Box 2001, Oak Ridge, TN 37830

85. W. A. Kocher, 1219 Riverbend Drive, Kingston, TN 37763

86. E. C. Leming, Director, DOE Oversight Division, 761 Emory Valley Road, Oak idge, TN 37830-7072

87. G. J. Marciante, Environmental Protection Division, SE-31, DOE Oak Ridge Field Office, P.O. Box 2001, Oak Ridge, Oak Ridge, TN 37830

88. A. D. McKinney, Chief, Environmental Services, TWRA, P.O. Box 40747, Ellington Agricultural Center, Nashville, TN 37204

89. W. G. McMillan, Environment and Protection, DOE Oak Ridge Field Office, P.O. Box 2001, Oak Ridge, TN 37830

90. C. R. Olsen, Environmental Sciences Division, Office of Health and Environmental Research, ER-74, U.S. Department of Energy, Washington, DC 20585

91. R. H. Olsen, Vice President for Research, University of Michigan, Medical Science Building II, \#5605, 1301 East Catherine Street, Ann Arbor, MI 48109-0620

92. A. Patrinos, Acting Director, Environmental Sciences Division, Office of Health and Environmental Research, ER-74, U.S. Department of Energy, Washington, DC 20585

93. S. S. Perkins, c/o Labat-Anderson, Inc., Information Resource Center, Administrative Record File, 105 Broadway, Oak Ridge, TN 37830

94. T. D. Richardson, Department of Biology, Box 504-A, University of North Alabama, Florence, AL 35632-0001

95. S. P. Riddle, Environmental Restoration Division, EW-91, DOE Oak Ridge Field Office, P.O. Box 2001, Oak Ridge, TN 37830

96. W. Schacher, Aquatic Habitat Protection Biologist, Tennessee Wildlife Resources Agency, 6032 W. Andrew Johnson Highway, Talbot, TN 37877

97. R. C. Sleeman, Environmental Restoration Division, EW-91, DOE Oak Ridge Field Office, P.O. Box 2001, Oak Ridge, TN 37830

98. D. Turner, 1201 Tuskegee Drive, Oak Ridge, TN 37830

99. F. J. Wobber, Environmental Sciences Division, Office of Health and Environmental Research, ER-74, U.S. Department of Energy, Washington, DC 20585

100. Office of Assistant Manager for Energy Research and Development, DOE Oak Ridge Field Office, P.O. Box 2001, Oak Ridge, TN 37831-8600

101-110. Office of Scientific and Technical Information, P.O. Box 62, Oak Ridge, TN 37831 

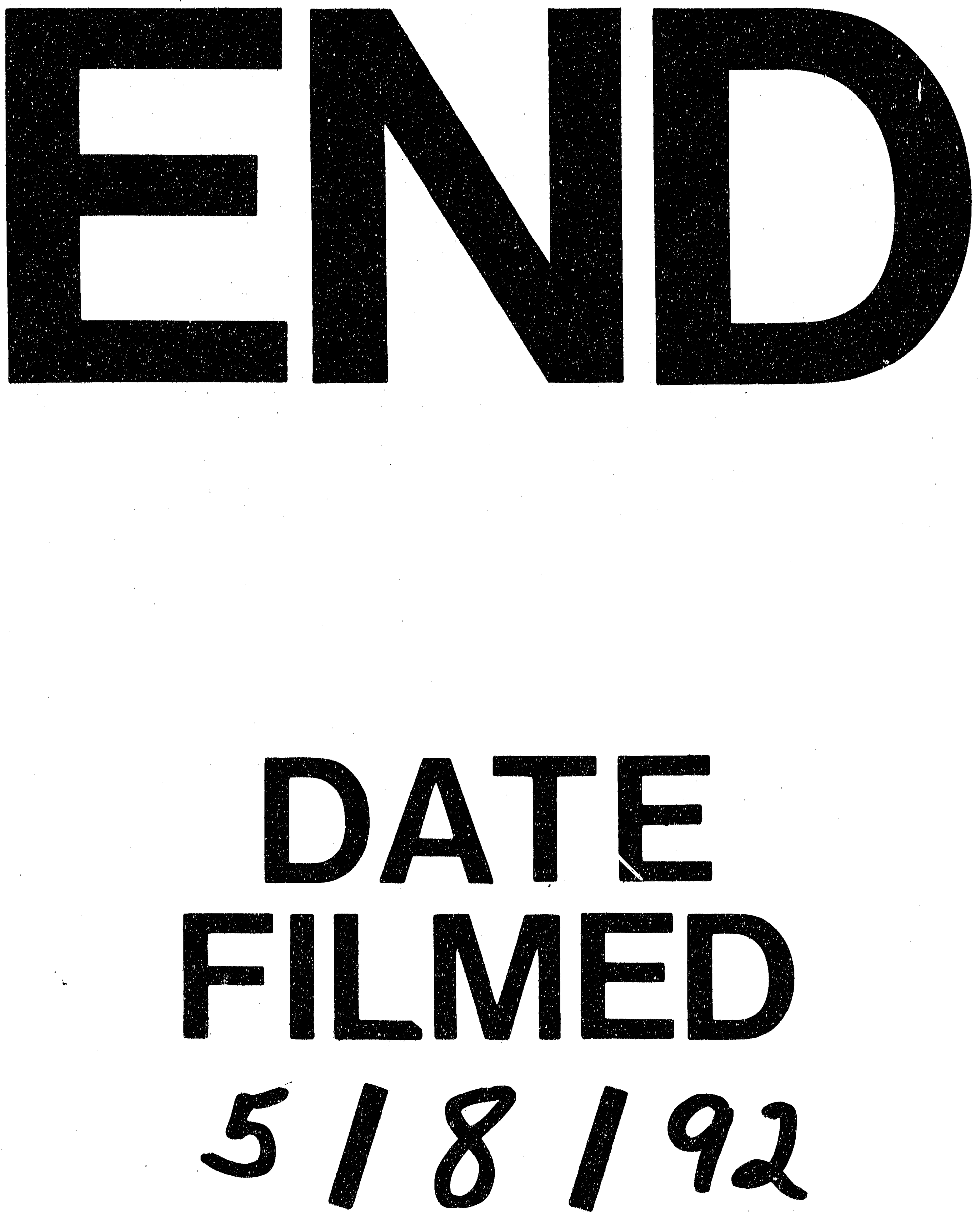

1 
